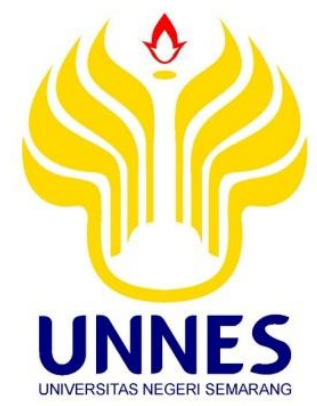

\title{
PENGGUNAAN MEDIA AUDIO VISUAL DALAM PEMBELAJARAN SENI BUDAYA SUB MATERI MUSIK DI SMK NEGERI 03 SALATIGA
}

\section{SKRIPSI}

diajukan sebagai salah satu syarat untuk memperoleh gelar Sarjana Pendidikan Program Studi Pendidikan Seni Musik

\author{
oleh \\ Angga Dwi Winarno \\ 2501413055
}
JURUSAN PENDIDIKAN SENI DRAMA, TARI, DAN MUSIK
FAKULTAS BAHASA DAN SENI UNIVERSITAS NEGERI SEMARANG




\section{PENGESAHAN KELULUSAN}

Skripsi ini telah dipertahankan dihadapan sidang Panitia Ujian Skripsi Jurusan Pendidikan Seni Drama, Tari dan Musik, Fakultas Bahasa dan Seni, Universitas Negeri Semarang

$$
\begin{array}{ll}
\text { pada hari } & \text { Selasa } \\
\text { tanggal } & : 12 \text { September } 2017
\end{array}
$$

\section{Panitia Ujian Skripsi}

Prof. Dr. Agus Nuryatin, M.Hum

NIP. 196008031989011001

Ketua

Dra. Malarsih, M.Sn

NIP. 196106171988032001

Sekretaris

Prof. Dr. Totok Sumaryanto F.

NIP. 196410271991021001

Penguji I

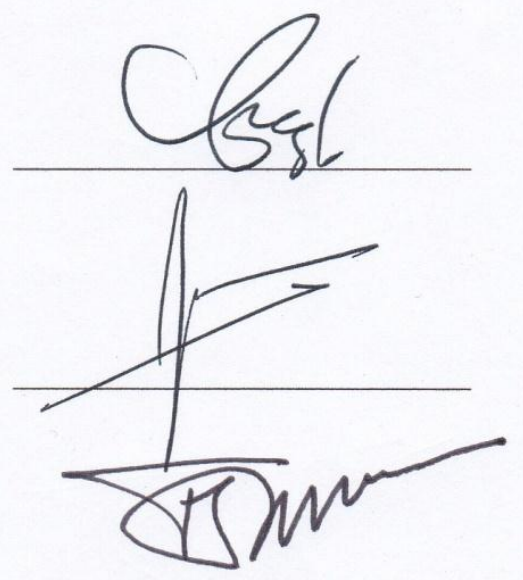

Mochammad Usman Wafa, S.Pd, M.Pd

NIP. 198012042015041001

Penguji II/Pembimbing II

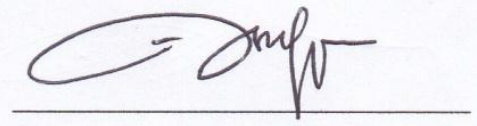

Dr. Wadiyo, M.Si

NIP. 195912301988031001

Penguji III/Pembimbing I

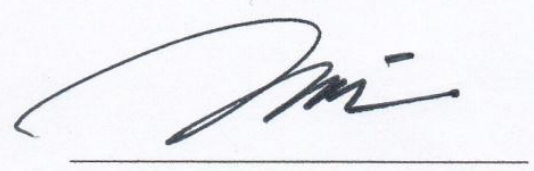

Prof. Dr. Agus Nuryatin, M.Hum

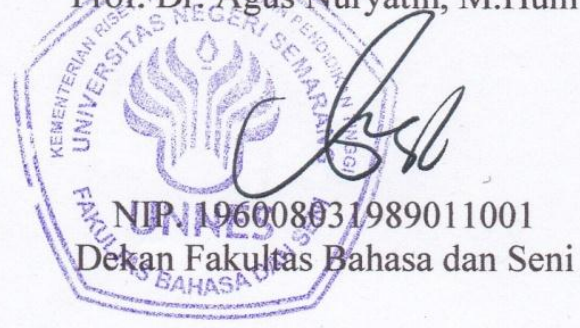




\section{PERNYATAAN}

Saya menyatakan bahwa yang tertulis di dalam skripsi ini benar-benar hasil karya saya sendiri, bukan jiplakan karya dari orang lain, baik sebagian atau seluruhnya. Pendapat atau temuan orang lain yang terdapat dalam skripsi ini dikutip atau dirujuk berdasarkan kode etik ilmiah.

Semarang. September 2017

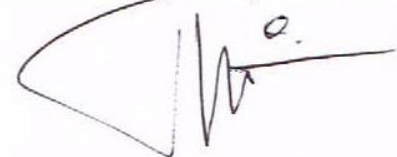

Angga Dwi Winarno 


\section{MOTTO DAN PERSEMBAHAN}

Motto :

“Tunjukkanlah kepadaku jalan-Mu, ya TUHAN, supaya aku hidup menurut kebenaran-Mu; bulatkanlah hatiku untuk takut akan nama-Mu." (Mazmur 86:11)

"Janganlah hendaknya kamu kuatir tentang apapun juga, tetapi nyatakanlah dalam segala hal keinginanmu kepada Allah dalam doa dan permohonan dengan ucapan syukur."(Filipi 4:6)

Skripsi ini saya persembahkan untuk :

1. Kedua orang tua saya, Bapak Suwondo dan Ibu Suparyati yang selalu memberikan kasih, dukungan dan motivasi dalam doa maupun materi.

2. Kedua kakak kandung saya, Agus Susilo yang selalu memberikan semangat.

3. Sahabat-sahabat prodi Pendidikan Seni Musik yang selalu memberikan semangat tanpa henti.

4. Almamater Unnes tercinta. 


\section{SARI}

Winarno, Angga Dwi. 2017. Penggunaan Media Audio Visual dalam Pembelajaran Seni Budaya Sub Materi Musik di SMK Negeri 03 Salatiga. Skripsi, Jurusan Pendidikan Seni Drama, Tari, dan Musik, Fakultas Bahasa dan Seni, Universitas Negeri Semarang. Dosen Pembimbing I Dr. Wadiyo. M.Si., Dosen Pembimbing II Mochmmad Usman Wafa, S.Pd, M.Pd.

Kata kunci: Media Audio Visual, Pembelajaran, Seni Budaya, Sub Materi Musik.

Teknologi pendidikan sering kali menggunakan peralatan atau mesin dan media lainnya. Proses belajar mengajar juga dituntut untuk menggunakan berbagai macam strategi pembelajaran untuk meningkatkan kualitas belajar siswa, untuk itu guru seni budaya menggunakan media audio visual untuk meningkatkan kualitas belajar siswa. Tujuan dari penelitian untuk mengetahui bagaimana penggunaan media audio visual dalam pembelajaran seni budaya sub materi seni musik di SMK Negeri 03 Salatiga.

Penelitian ini menggunakan metode penelitian kualitatif deskriptif dengan desain penelitian studi kasus. Lokasi penelitian dilakukan di SMK Negeri 03 Salatiga kelas $\mathrm{X}$ jurusan ototronika dan teknik sepeda motor. Teknik pengumpulan data yang dilakukan adalah wawancara, observasi dan studi dokumen. Penelitian ini menggunakan teknik keabsahan data triangulasi sumber dengan uji kredibilitas data. Teknik analisis data menggunakan analisis data model interaktif.

Hasil dari penelitian ini adalah pada tahap perencanaan guru mengembangkan silabus, menyusun Rencana Pelaksanaan Pembelajaran (RPP) dan menyiapkan materi dan media pembelajaran dengan baik. Dalam penyusunan RPP, guru menyesuaikan kompetensi dasar yang ada pada Silabus sebagai acuan dan menyesuaikan keadaan yang ada di SMK Negeri 03 Salatiga. Pada tahap pelaksanaan guru membuka pembelajaran dengan menanyakan jenis-jenis genre musik, selanjutkan guru memperliatkan contoh pergelaran musik dengan menggunakan media audio visual. Setelah siswa memperhatikan contoh video guru mempersilahkan siswa untuk berdiskusi dan mempersiapkan sajian masingmasing kelompok. Dalam kegiatan mempergelarkan seni siswa sangat antusias dalam menyajikan sajiannya dan memperhatikan kelompok yang tampil . Pada tahap evaluasi, guru sudah melaksanakan kegiatan apresiasi kepada siswa yang telah tampil masing-masing kelompok. Guru juga memberikan tugas kepada siswa untuk membuat evaluasi kepada kelompok lain yang sudah menampilkan sajiannya.

Saran untuk penelitian ini adalah (1) sebaiknya guru mencantumkan media dalam RPP tidak hanya video saja, tapi guru juga mempratekkan secara langsung kepada siswa (2) dalam pelaksanaannya guru memberikan waktu terlalu lama dalam mempersiapkan pergelaran seni budaya dan guru harus memperhatikan saat para siswa diskusi maupun latihan, (3) tahap evaluasi sudah sesuai dengan tahapan dan dapat dipertahankan. 


\section{PRAKATA}

Puji syukur peneliti panjatkan kehadirat Tuhan Yang Maha Esa (YME), atas segala rahmat-Nya yang telah diberikan kepada peneliti sehingga skripsi yang berjudul "Penggunaan Media Audio Visual dalam Pembelajaran Seni Budaya Sub Materi Musik di SMK Negeri 03 Salatiga", dapat diselesaikan dengan baik tanpa menemui hambatan yang berarti.

Skripsi ini disusun guna memenuhi salah satu syarat kelulusan Strata Satu (SI) pada jurusan Pendidikan Seni Drama Tari dan Musik, Fakultas Bahasa dan Seni, Universitas Negeri Semarang. Tujuan mendasar dari skripsi ini adalah untuk mengukur sejauh mana kemampuan peneliti dalam menuangkan ide ke dalam bentuk tulisan yang tersusun secara rapi, dan juga dalam mengorganisir dan mengintregasikan pengetahuan, penelitian, pengalaman dan kecakapan yang bersifat ilmiah.

Peneliti mengucapkan terimakasih kepada pihak-pihak yang telah banyak memberikan dorongan, bantuan, dan petunjuk yang sangat berarti besar bagi penyusunan skripsi ini. Pada kesempatan ini, peneliti ingin menyampaikan terimakasih yang sebesar-besarnya kepada :

1. Prof. Dr. Fathur Rokhman, M.Hum., Rektor Universitas Negeri Semarang, yang telah memberikan kesempatan untuk menyelesaikan studi di Pendidikan Sendratasik FBS Universitas Negeri Semarang.

2. Prof. Dr. Agus Nuryatin, M.Hum., Dekan Fakultas Bahasa dan Seni Universitas Negeri Semarang yang juga telah memberikan ijin penelitian kepada peneliti.

3. Dr. Udi Utomo, M.Si., Ketua Jurusan Pendidikan Seni Drama Tari dan Musik, Fakultas Bahasa dan Seni, Universitas Negeri Semarang, yang telah membantu proses perizinan penelitian dan yang telah meluangkan waktu dalam memberikan arahan, bimbingan, dan saran kepada peneliti dengan sabar dan bijaksana. 
4. Dr. Wadiyo, M.Si., Dosen pembimbing I yang senantiasa dengan sabar membimbing dan mengarahkan peneliti dalam penyusunan skripsi.

5. Mochammad Usman Wafa, S.Pd, M.Pd., Dosen pembimbing II yang senantiasa dengan sabar membimbing dan mengarahkan peneliti dalam penyusunan skripsi.

6. Suripan, S.Pd., Kepala SMK Negeri 03 Salatiga, yang telah memberikan ijin kepada peneliti untuk melakukan penelitian.

7. Sulistyo, S.Pd., guru seni musik SMK Negeri 03 Salatiga, yang telah membantu memberikan informasi kepada peneliti selama penelitian.

8. Semua pihak yang tidak dapat peneliti sebutkan satu-persatu yang telah terlibat, baik secara langsung maupun tidak langsung selama peneliti menjalankan proses pembuatan skripsi.

Semoga jasa baik dari semua pihak yang telah membantu dengan ikhlas kepada peneliti menjadi amal baik dan mendapatkan imbalan yang setimpal dari Tuhan YME. Semoga skripsi ini bermanfaat bagi pembaca khususnya dan dunia pendidikan pada umumnya.

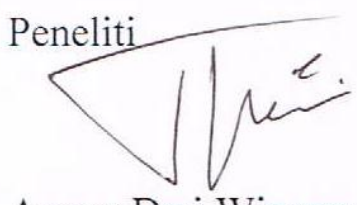

Angga Dwi Winarno 


\section{DAFTAR ISI}

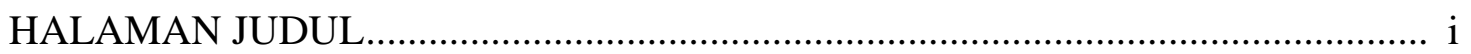

PERSETUJUAN PEMBIMBINGAN ................................................................. ii

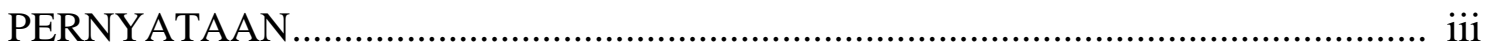

MOTTO DAN PERSEMBAHAN ……........................................................ iv

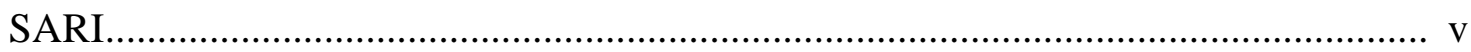

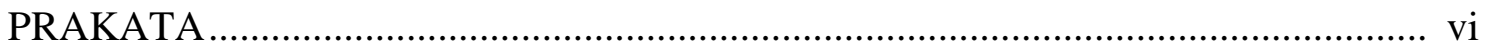

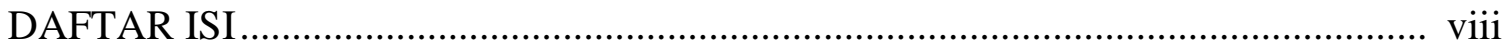

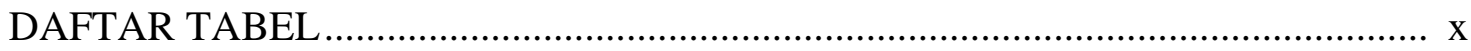

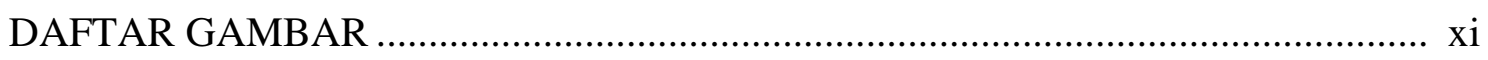

DAFTAR LAMPIRAN .............................................................................. xii

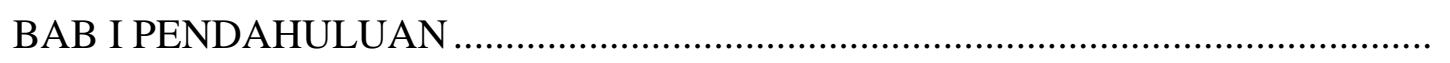

1.1 Latar Belakang Masalah............................................................................. 1

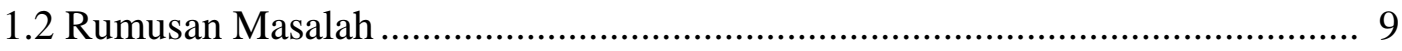

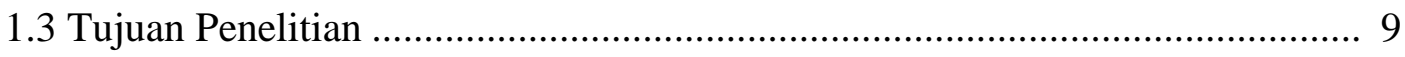

1.4 Manfaat Penelitian .............................................................................. 10

1.5 Sistematika Penulisan Skripsi ................................................................. 11

BAB II KAJIAN PUSTAKA DAN LANDASAN TEORETIS ................................ 13

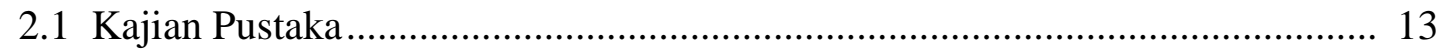

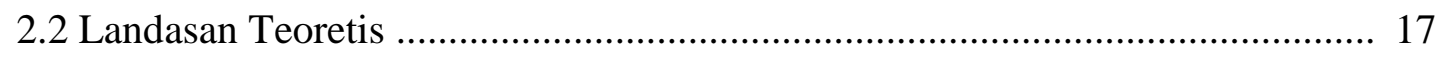

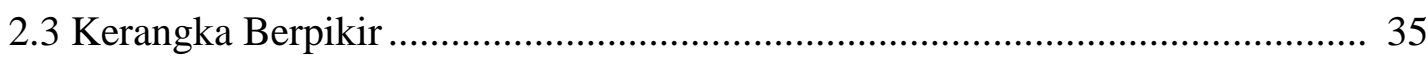

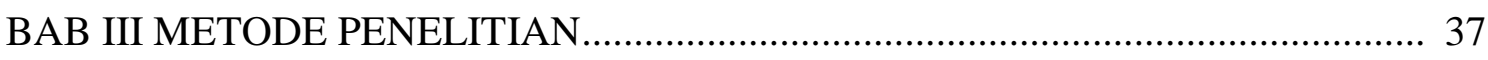

3.1 Pendekatan Penelitian .......................................................................... 37 


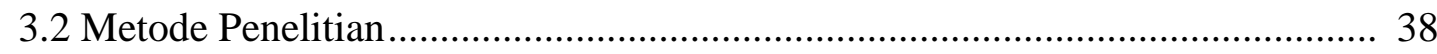

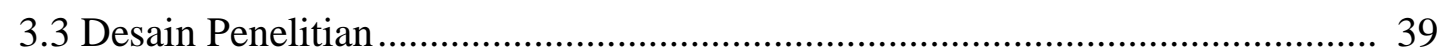

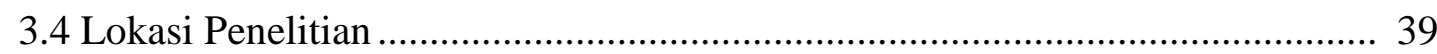

3.5 Sasaran Kajian dalam Penelitian ................................................................. 40

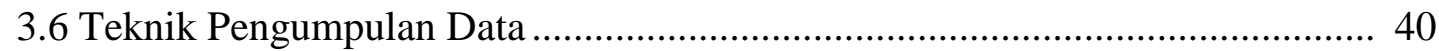

3.7 Teknik Keabsahan Data ....................................................................... 44

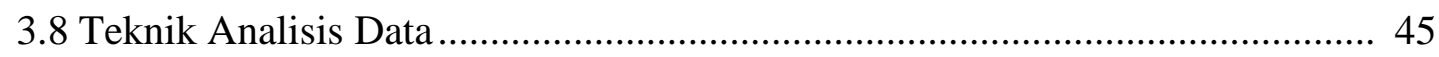

BAB IV HASIL PENELITIAN DAN PEMBAHASAN ...................................... 47

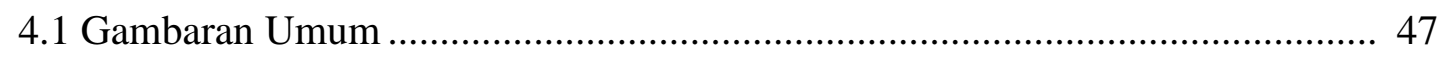

4.2 Penggunaan Media Audio Visual dalam Pembelajaran Seni Budaya Sub

Materi Musik di SMK Negeri 03 Salatiga ................................................. 61

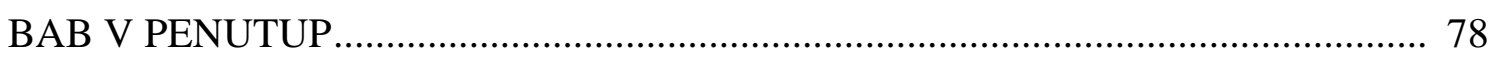

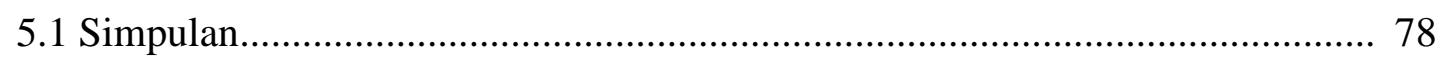

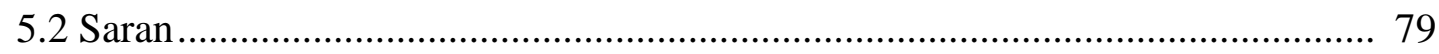

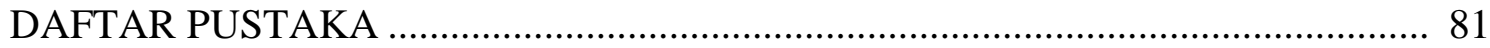

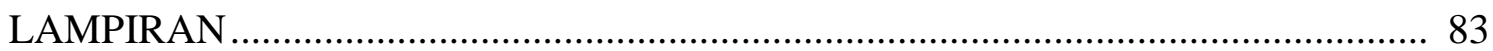




\section{DAFTAR TABEL}

Tabel 4.1Tenaga Pengajar dan Karyawan SMK Negeri 03 Salatiga ....................52

Tabel 4.2 Daftar Alat Musik SMK Negeri 03 Salatiga......................................60 


\section{DAFTAR GAMBAR}

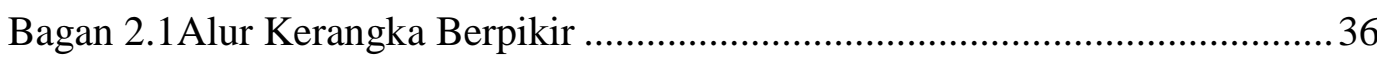

Bagan 3.1 Komponen-Komponen Analisis Data Model Interaktif.......................46

Gambar 4.1 Gerbang Sekolah SMK Negeri 03 Salatiga................................... 48

Gambar 4.2 Kondisi Studio Musik SMK Negeri 0 Salatiga ............................... 61

Gambar 4.3 Guru Melakukan Pembukaan Pembelajaran …............................... 68

Gambar 4.4 Keadaan Saat Mengamati Contoh Pementasan Seni ........................ 71

Gambar 4.5 Keadaan Saat Guru Membuka Pergelaran Seni ............................... 72

Gambar 4.6 Proses Pergelaran Seni Budaya ................................................... 74

Gambar 4.7 Guru Melakukan Menutup Pelajaran. ........................................... 75

Gambar 4.8 Proses Evaluasi Pergelaran Seni Budaya. ....................................... 77 


\section{DAFTAR LAMPIRAN}

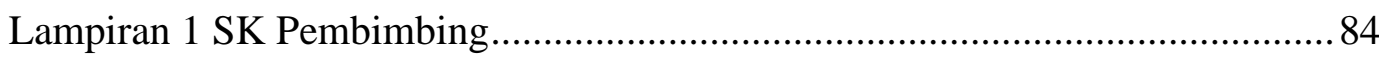

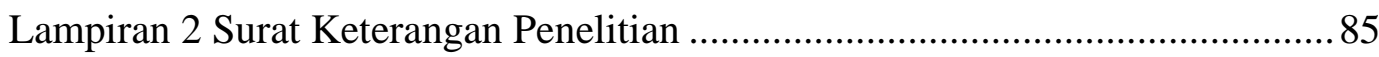

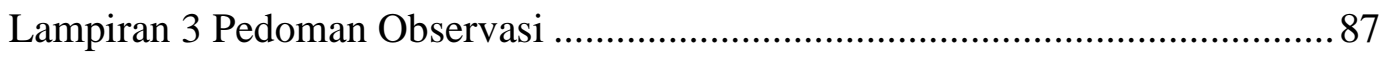

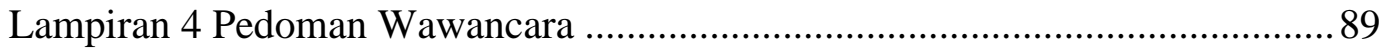

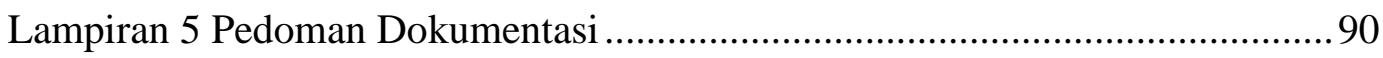

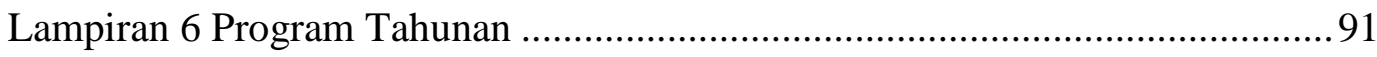

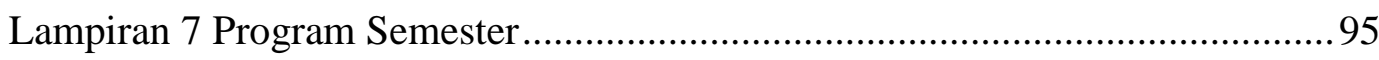

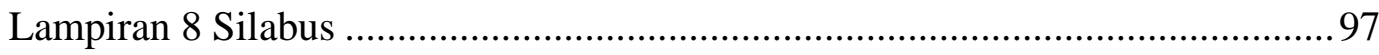

Lampiran 9 Rencana Pelaksanaan Pembelajaran.............................102

Lampiran 10 Kalender Pendidikan....................................... 116

Lampiran 11 Data Siswa Sekolah..................................... 117

Lampiran 12 Struktur Organisasi Sekolah.............................. 121

Lampiran 13 Hasil Wawancara...................................... 122

Lampiran 14 Dokumentasi............................................ 124 


\section{BAB I \\ PENDAHULUAN}

\subsection{Latar Belakang Masalah}

Era globalisasi saat ini perkembangan teknologi sangatlah pesat yang saat ini telah memberikan banyak manfaat diberbagai aspek. Penggunaan teknologi oleh manusia untuk menyelesaikan berbagai suatu pekerjaan merupakan suatu keharusan. Manusia sebagai pengguna teknologi haruslah mampu untuk memanfaatkan yang ada saat sekarang ini, maupun perkembangan teknologi selanjutnya. Dengan hal ini, lembaga pendidikan terutama di sekolah sangat memanfaatkan perkembangan teknologi ini untuk menunjang proses belajar mengajar. Pengertian teknologi pendidikan sering kali menggunakan peralatan atau mesin dan media lainnya. Teknologi pendidikan (educational technology) atau teknologi pengajaran (instructional technology) secara umum merupakan sebagai penerapan teknologi, khususnya pada teknologi komunikasi, untuk kegiatan proses pengajaran dalam pendidikan. Maka dalam lembaga pendidikan mengenai proses belajar mengajar untuk meningkatkan kualitas belajar siswa didalam pendidikan dituntut untuk menggunakan berbagai macam strategi pembelajaran.

Sekarang banyak sekali peralatan elektronik yang sangat membantu proses dalam belajar mengajar di sekolah formal. Merk-merk peralatan elektronik sangatlah bersaing dan memberikan keunggulan setiap produknya demi menyakinkan kosumen. Sekolah serupakan konsumen yang berperan dalam setiap 
pembelian barang-barang elektronik. Tentu saja barang elektronik yang menunjang fasilitas sekolahan, seperti LCD proyektor, TV, VCD, tape recorder, sound/alat pengeras suara dan komputer/laptop. Semua ini disediakan untuk menunjang fasilitas-fasilitas di setiap ruang kelas. Tujuannya untuk membuat suasana belajar mengajar yang tidak membosankan untuk murid dan para pengajar. Jadi setiap alat-alat elektronik tersebut dapat dimanfaat setiap pengajar untuk membuat inova-inovasi dalam mengajar. Setiap pengajar juga dituntut untuk dapat mengoprasikan setiap alat media pembelajaran yang ada. Dengan demikian maka belajar mengajar akan terliat tidak membosankan dan mempermudah pengajar untuk menyampaikan materi pembelajaran. Namun tidak sedikit sekolahan yang belum atau belum lengkap dalam bisa menberikan fasilitas-fasilitas media pembelajaran tersebut. Akibatnya pengajar yang ingin berinovasi dalam proses mengajarnya menjadi terhambat dan terpaksa memakai metode ceramah. Padahal media pembelajaran tersebut sangat membantu dalam menerapkan setiap kurikulum yang sudah dirancang dalam pendidikan di sekolahan.

Undang-undang R.I. No. 20 tahun 2003, Bab I, Pasal 1 menjelaskan pendidikan merupakan usaha sadar untuk menyiapkan peserta didik melalui kegiatan bimbingan, pengajaran, dan atau latihan bagi peranannya dimasa yang akan datang. Kurikulum perlu didesentralisasikan terutama dalam pengembangan silabus dan pelaksanaannya yang berperan dalam salah satu substansi pendidikan disesuaikan dengan kebutuhan siswa keadaan sekolah dan kondisi sekolah atau daerah. Sesuai dengan ketentuan tersebut, sekolah memiliki potensi yang luas 
untuk melakukan sebuah perubahan dan mengembangkan variasi-variasi penyelenggaraan pendidikan sesuai dengan keadaan, potensi, dan kebutuhan serta kondisi siswa. Didalam Undang-undang No. 20 tahun 2003 pasal 13 ayat 1 menjelaskan bahwa jalur pendidikan terdiri dari pendidikan formal, informal, dan non-formal.

Pendidikan formal merupakan pendidikan yang diselenggarakan di sekolah-sekolah pada umumnya. Pendidikan ini mempunyanyi jenjang pendidikan yang sangat jelas karena dari pendidikan dasar, pendidikan menengah dan pendidikan atas. Pendidikkan informal memiliki jalur pendidikan keluarga dan lingkungan berbentuk kegiatan belajar secara mandiri yang dilakukan secara sadar dan bertanggungjawab. Pendidikan ini tidak memerlukan tempat khusus untuk melakukan pembelajaran dan untuk materi memiliki jalur pendidikan yang diluar dari pendidikan formal yang dapat dilaksanakan secara struktur dan berjenjang. Pendidikan ini mempunyai fungsi tersendiri yaitu sebagai pengganti, penambah dan pelengkap.

Pendidikan sangat penting yaitu sebagai sarana untuk meningkatkan kualitas sumber daya manusia, sehingga tenaga pendidik sebagai guru menjadi unsur yang berperan penting didalamnya. Pada dasarnya pembelajaran dikatakan berhasil apabila guru dapat menguasai kelasnya dan hasil belajar dapat meningkat. Akan tetapi guru cenderung mengabaikan menggunakan media pembelajaran karena guru tidak yakin menggunakannya dalam proses pembelajaran. Akhirnya siswa menjadi malas mendengarkan guru dan materi yang telah disampaikan 
tidak sepenuhnya dipahami siswa, sehingga dari hasil belajar siswa berdampak rendah.

Suatu pembelajaran memiliki sebuah proses dimana peserta didik dengan pendidik saling interaksi pada suatu lingkungan tempat belajar. Dalam proses pembelajaran di sekolah ada beberapa bidang ilmu yang disajikan kepada siswa, kesemuanya itu bertujuan agar siswa menguasai ilmu pengetahuan dan ketrampilan yang kelak akan bermanfaat bagi dirinya dan dapat bersaing dalam dunia kerja yang ada. Setiap bidang ilmu itu mengandung tiga unsur yaitu kognitif (pengetahuan), afektif (sikap), dan sikap psikomotorik (ketrampilan). Diantara bidang tersebut, pembelajaran seni budaya di Sekolah Menengah Pertama (SMK) khususnya pembelajaran musik pada dasarnya di arahkan untuk menumbuhkan perkembangan kreativitas siswa, sehingga akan terbentuk sikap apresiatif, kritis, motivatif dan proses kreatif dalam diri siswa. Kemampuan ini akan tumbuh jika dalam setiap aktifitas seni musik dilakukan serangkaian kegiatan yang meliputi pengamatan analisis, penilaian, serta kreasi, baik di dalam kelas maupun diluar kelas.

Pembelajaran ini dirancang agar peserta didik dapat mencapai tujuan yang telah ditetapkan. Tujuan belajar sebenarnya dapat dilakukan peserta didik dengan cara membaca buku, majalah, surat kabar atau mengamati peristiwa di lingkungannya. Dalam proses pembelajaran akan melibatkan komponenkomponen pembelajaran. Komponen-komponen tersebut adalah tujuan, subyek belajar, materi pelajaran, strategi, media, evaluasi dan penunjang. Untuk menuju tujuan dalam pembelajaran selain berbagai komponen-komponen tersebut, hal 
yang menunjang keberhasilann dalam mencapai tujuan pembelajaran yaitu siswa. Namun siswa di rumah tidak mengulangi pelajaran yang sudah diajarkan, terbukti pada saat dilakukan tanya jawab, hanya sebagian kecil siswa yang aktif menjawab pertanyaan dari guru. Selain itu kebiaasaan siswa dalam mengerjakan tugas juga berpengaruh dalam proses belajar mengajar. Oleh karena itu, pemilihan media pembelajaran yang tepat itu penting karena dapat menunjang tersampainya materi ke peserta didik dengan baik.

Pentingnya media dalam pembelajaran akan membantu siswa agar semangat dalam mengikuti proses pembelajaran, sehingga siswa dapat memahami materi dengan baik karena siswa akan mengingat pembelajaran yang berkesan. Kreativitas siswa akan meningkat dari sebelumnya. Salah satu media pembelajaran yang baik digunakan dalam pembelajaran adalah media audio visual yang mengandalakan indra penglihatan dan pendengaran. Media pembelajaran dapat disajikan secara tekstual, animasi, video, dan gambar. Perpaduan penyajian tersebut diharapkan peserta didik akan lebih termotivasi dan merasa tidak cepat bosan.

Media sebagai jenis komponen yang berperan dalam lingkungan siswa untuk menunjang dalam belajar. Media pembelajaran dalam proses belajar mengajar bisa memunculkan kemauan, membangkitkan motivasi dan rangsangan kegiatan belajar dan bahkan menimbulkan pengaruh psikologis terhadap siswa. Jadi dengan adanya media pembelajaran diharapkan siswa akan termotivasi untuk belajar lebih giat lagi. Media ada terdiri dari media audio, media visual dan pergabungan media audio dan visual yaitu media audio visual. Peneliti tertarik 
untuk membahas penggunaan media audio visual di pembelajaran seni budaya. Dengan menggunakan media audio visual di harapkan membuat anak tertarik dan mudah memahami materi yang disampaikan. Penelitian tentang penggunaan media pembelajaran audio visual juga pernah dilakuan, salah satunya oleh Shadila deykisy dengan judul penelitian penggunaan media audio visual dalam pembelajaran lagu daerah setempat untuk motivasi belajar siswa di SMK Negeri 1 Ranah Pesisir. Penelitian ini lebih meneliti tentang penggunaan media sebagai motivasi belajar siswa, berbeda dengan penelitian ini yang lebih ke arah proses penggunaan media dalam pembelajaran.

Media audio merupakan segala yang berhubungan dengan indera pendengaran dengan macam-macam betuk media yang berkaitan, termasuk dalam kelompok media audio (Hujair Sanaky 2013 : 6). Karena media audio berkaitan dengan indera pendengaran, maka pesan yang akan disampaikan dituangkan ke dalam lambang-lambang auditif, baik verbal (kata-kata atau bahasa lisan) maupun non verbal. Media visual merupakan segala macam bentuk media yang dapat dilihat dengan indra penglihat (mata). Media berbasis visual dapat memperlancar pemahaman dan memperkuat ingatan untuk itu media visual memegang peranan penting dalam proses belajar. Visual dapat juga menumbuhkan minat siswa dan dapat memberikan hubungan antara isi materi pelajaran dengan dunia nyata. Media audio-visual merupakan seperangkat alat yang dapat menampilkan gambar bergerak dan menghasilkan suara, media audio visual ini menggunakan indra penglihatan dan pendengaran (Hujair Sanaky 2013 : 119). Alat-alat yang temasuk dalam kategori media audio-visual adalah : televisi, video-VCD, sound slide, dan 
film. Media pembelajaran audio visual ini sangatlah membantu di proses belajar mengajar salah satunya yaitu pelajaran Seni Budaya (seni musik).

Seni Budaya bisa diartikan segala sesuatu yang diciptakan manusia mengenai cara hidup berkembang secara bersama pada suatu kelompok yang mengandung unsur keindahan (estetika) secara turun temurun dari generasi ke generasi. Seni Budaya di SMK merupakan salah satu pelajaran yang sangat membantu peserta didik untuk belajar sekreatif mungkin. Seni Budaya bukan aktivitas dan materi pembelajaran yang dirancang hanya untuk mengasah kompetensi ketrampilan peserta didik. Seni Budaya harus mencangkup aktivitas dan materi pembelajaran yang memberikan kompetensi pengetahuan tentang karya seni budaya dan kompetensi sikap yang terkait dengan seni budaya. Ranah seni budaya yaitu seni rupa, seni tari, seni musik dan seni teater yang diangkat sebagai seni yang merupakan warisan budaya bangsa.

Seni musik merupakan salah satu bidang kajian mata pelajaran Seni Budaya dan setiap bidang kajian mempunyai tujuan untuk membuat siswa menjadi kreatif dalam belajar seni. Untuk mencapai tujuan, peranan pengajar sangatlah ambil peran dalam hal ini. Karena peranan peranan guru musik adalah menciptakan kondisi musikal yang kondusif, sehingga siswa dapat mengalami dan memahami suatu pembelajaran dalam seni budaya terutama dalam seni musik. Sama dengan apa yang dilakukan guru SMK Negeri 03 Salatiga untuk mencapai tujuan dari pembelajaran, beliau menggunakan strateri pembelajaran yaitu sebuah media pembelajaran untuk mempermudah penyampaian meteri kepada siswa. 
Berdasarkan uraian tersebut penulis berharap dapat meyakinkan bahwa untuk menggunakan media pembelajaran dalam proses belajar mengajar dapat menambah inovasi-inovasi media pembelajaran. Salah satunya adalah media pembelajaran audio-visual karena media ini cocok digunakan kesemua materi Seni Budaya. Dalam penyampaian materi praktis dan dapat dipahami siswanya, siswa akan termotivasi dalam belajar dan berpusat pada materi pelajaran. harapannya hasil belajar siswa akan meningkat dan tujuan pembelajaran akan tercapai.

Motivasi belajar Seni Budaya dipengaruhi berbagai faktor, diantaranya guru, siswa, bahan ajar, dan sarana prasarana. Berdasarkan wawancara dengan salah satu pengajar seni budaya di SMK Negeri 03 Salatiga. Masih banyak siswa yang belum terlalu mengerti tentang materi seni budaya khususnya seni musik yang telah di ajarkan oleh pengajar. Permasalahan ini ada beberapa faktor yang menghambat proses belajar mengajar yaitu sarana prasarana yang masih kurang begitu memadahi. Jadi pengajar juga tidak bisa berbuat banyak untuk mengajarkan materi-materi yang akan disampaikan dan tidak bisa melakukan inovasi-inovasi yang mendukung proses belajar mengajar.

Permasalahan pembelajaran seni musik juga terjadi di SMK Negeri 03 Salatiga. Jadi selama ini pengajar masih belum maksimal dalam menggunakan media pembelajaan audio-visual dikarenakan di setiap ruang kelas tidak di lengkapi oleh sarana prasarana yang mendukung untuk melakukan pembelajaran audio-visual. Apabila ingin melakuan pembelajaran audio-visual pengajar harus membawa sendiri alat-alat yang mendukung pembelajaran tersebut. Karena alat- 
alat seperti pengeras suara di sekolahan hanya menyediakan beberapa saja, jadi pengajar-pengajar di SMK Negeri 03 Salatigasaling rebutan media pembelajaran tersebut. Padahal jika pengajar hanya menyampaikan materi seni budaya secara lisan maka siswa cenderung bosan dan mudah melupakan materi yang telah disampaikan. Sebagian besar mereka pasif dalam menerima pelajaran dan kurang ada motivasi belajar. Sehingga proses pembelajaran yang berlangsung tidak efektif dan mengakibatkan tujuan pembelajaran tidak maksimal.

Berdasarkan latar belakang, peneliti akan mengkaji permasalahan pembelajaran seni musik melalui penelitian tentang "Penggunaan Media Audio Visual dalam Pembelajaran Seni Budaya Sub Materi Musik di SMK Negeri 03 Salatiga".

\subsection{Rumusan Masalah}

Mengingat pembahasan mengenai kajian pembelajaran seni musik berbantu media audio visual ini sangat luas, maka pembahasanya dapat difokuskan dengan adanya rumusan masalah yaitu, bagaimana penggunaan media audio visual dalam pembelajaran seni budaya sub materi musik di SMK Negeri 03 Salatiga.

\subsection{Tujuaan Penelitian}

Berdasarkan rumusan masalah yang telah diuraikan diatas, maka tujuan dari penelitian ini adalah untuk mengetahui dan menjelaskan penggunaan media 
audio visual dalam pembelajaran seni budaya sub materi di SMK Negeri 03 Salatiga.

\subsection{Manfaat Penelitian}

Hasil dari penelitian ini diharapkan dapat bermanfaat dalam perkembangan ilmu pengetahuan dan ilmu seni budaya khususnya dibidang seni musik. Penelitian ini juga diharapkan dapat memberikan manfaat baik secara teoretis maupun praktis, antara lain :

\subsubsection{Manfaat Secara Teoretis}

Penelitian ini diharapkan dapat memberi manfaat teoretis berupa informasi untuk dapat dikembangkan penelitian berikutnya tentang penggunaan media audio visual dalam pembelajaran seni budaya dibidang seni musik.

\subsubsection{Manfaat Secara Praktis}

\subsubsection{Bagi Siswa}

Penelitian ini bagi siswa diharapkan bisa memberikan manfaat sebagai berikut :

a) Ketertarikan siswa terhadap pembelajaran semakin meningkat

b) Mendapatkan pengalaman belajar yang bervariasi

c) Meningkatkan pemahaman siswa mengenai materi

\subsubsection{Bagi Guru}

Penelitian ini bagi guru diharapkan memberikan manfaat sebagai berikut:

a) Memberikan gambaran kepada guru tentang dampak penggunaan media pembelajaran audio visual

b) Menyediakan alternatif media pembelajaran yang menunjang pembelajaran 
c) Memotivasi guru untuk menggunakan media pembelajaran yang bervariasi dalam proses pembelajaran

\subsubsection{Bagi Sekolah}

Penelitian ini bagi sekolah diharapkan memberikan manfaat sebagai berikut:

a) Menambah pengetahuan baru mengenai media-media pembelajaran yang dapat digunakan dalam proses pembelajaran sehingga bisa meningkatkan kualitas pembelajaran di sekolah.

b) Hasil penelitian ini dapat dijadikan alat evaluasi untuk meningkatkan efektifitas proses pembelajaran.

\subsection{Sistematika Skripsi}

Secara garis besar sistematika penulisan skripsi sebagai berikut:

\subsubsection{Bagian awal skripsi berisi tentang:}

Sampul berjudul, lembar berlogo, judul dalam, persetujuan pembimbing, pengesahan kelulusan, pernyataan, motto dan persembahan, sari penelitian, prakata, daftar isi, daftar tabel, daftar gambar, daftar bagan, daftar lampiran.

1.5.2 Bagian isi terdiri dari:

\section{BAB I PENDAHULUAN}

\subsection{Latar Belakang Masalah}

1.2 Rumusan Masalah

1.3 Tujuan Penelitian

1.4 Manfaat Penelitian. 
1.5 Sistematika Skripsi

BAB II TINJAUAN PUSTAKA DAN LANDASAN TEORETIS

2.1 Tinjauan Pustaka

2.2 Landasan Teoretis

2.3 Kerangka Berpikir

BAB III METODE PENELITIAN

3.1 Pendekatan Penelitian

3.2 Metode Penelitian

3.3 Desain Penelitian

3.4 Lokasi Penelitian

3.5 Sasaran Penelitian

3.6 Teknik Pengumpulan Data

3.7 Teknik Keabsaan Data

3.8 Teknik Analisis Data

BAB IV HASIL PENELITIAN DAN PEMBAHASAN

4.1 Gambaran Umum

4.2 Penggunaan Media Audio Visual dalam Pembelajaran Seni Budaya Sub Materi Musik di SMK Negeri 03 Salatiga

BAB V PENUTUP

5.1 Simpulan

5.2 Saran

1.5.3 Bagian akhir terdiri dari:

Daftar pustaka dan lampiran. 


\section{BAB II \\ TINJAUAN PUSTAKA}

Bab ini akan diuraikan mengenai kajian pustaka, landasan teoretis, dan kerangka berpikir sebagai berikut.

\subsection{Kajian Pustaka}

Penelitian tentang penggunaan media audio visual dalam pembelajaran ini bukan satu-satunya penelitian yang dilakukan oleh penulis. Ada beberapa refrensi yang menginspirasi penulis untuk melakukan penelitian ini. Salah satu contohnya penelitian yang mempunyai hubungan yang sama dengan penelitian yang diambil oleh penulis dari beberapa sumber.

Sumber pertama adalah yang dilakukan oleh Shadila Deykisy (2013), yang berjudul "Penggunaan Media Audio Visual dalam Pembelajaran Lagu Daerah Setempat untuk Motivasi Belajar Siswa di SMK Negeri 1 Ranah Pesisir". Penelitian dengan jenis penelitian kualitatif dengan metode deskriptif. Berdasarkan hasil penelitian tersebut diketahui bahwa peningkatan motivasi siswa dalam pembelajaran lagu setempat, hal itu terlihat dari kegiatan proses belajar mengajar di kelas seperti, siswa tampak antusias dalam menyaksikan video lagu daerah setempat yang guru tampilkan, siswa memperhatikan video lagu daerah setempat yang ditampilkan, siswa mengerjakan tugas secara perkelompok dengan tepat waktu. Dari hasil peneitian yang sudah dilakukan dapat dilihat motivasi siswa dalam pembelajaran lagu daerah setempat dengan menggunakan media pembelajaran audio visual. Dalam penelitian ini Shadila Deykisy hanya 
membahas motivasi belajar siswa dengan materi lagu daerah setempat dengan memanfaatkan penggunaan media pembelajaran audio visual.

Sumber kedua adalah yang dilakukan oleh Novi Sugianti Rahayu (2013), yang berjudul "Peningkatan Keterampilan Menyanyikan Lagu Daerah Melalui Model Direct Instruction Berbantu Media Audiovisual pada Siswa Kelas IV SDN Sampangan 01 Semarang”. Penelitian merupakan jenis penelitian tindakan kelas dengan menggunakan model Direct Instruction berbantu media audiovisual. Berdasarkan hasil penelitian tersebut diketahui bahwa model Direct Instruction berbantu media audio visual dapat meningkatkan keterampilan menyanyikan lagu daerah siswa. Hasil keterampilan menyanyikan lagu daerah siswa telah mencapai indikator keberhasilan yang telah ditetapkan yaitu ketuntasan klasikal sekurangkurangnya $85 \%$, dengan KKM mata pelajaran seni musik di kelas IV SDN Sampangan 01 Semarang tahun pelajaran 2012/2013 sebesar 62. Model Direct Instruction berbantu media audio visual juga dapat meningkatkan aktivitas siswa dalam pembelajaran menyanyikan lagu daerah dan meningkatkan keterampilan guru dalam pelajaran manyanyi lagu daerah. Dengan demikian bahwa model Direct Instruction berbantu media audio visual terbukti kebenarannya meningkatkan keterampilan menyanyikan lagu daerah pada siswa kelas IV SDN Sampangan 01 Semarang.

Sumber ketiga adalah yang dilakukan oleh Lidya Fita Kusumadewi (2010), yang berjudul "Peningkatan Hasil Belajar Seni Musik dengan Media Audio Visual Melalui Metode Bervariasi”. Penelitian merupakan jenis teknik analisis data yang digunakan adalah dengan deskriptif kuantitatif dan deskriptif 
kualitatif. Berdasarkan hasil penelitian tersebut diketahui bahwa dengan pembelajaran audio visual dan metode variasi dapat ditarik kesimpulan : (1) Meningkatkan hasil belajar siswa kelas VII A SMP N 1 Jambu pada mata pelajaran seni budaya tahun 2009/2010. Terbukti adanya peningkatan presentase ketuntasan belajar siswa dari $30 \%$ pada pra siklus, meningkat menjadi $84 \%$ pada siklus 1 dan $88 \%$ pada siklus 2. (2) Meningkatkan aktivitas belajar siswa kelas VII A SMP N 1 Jambu pada mata pelajaran seni budaya 2009/2010. Terbukti dari 33 siswa yang aktivitasnya kurang baik pada prasiklus dengan rata-rata skor 2,58 mengalami peningkatan pada siklus 1 menjadi 3,82 dengan kualifikasi cukup dan pada siklus 2 menjadi 4,02 atau kualifitasi baik.

Sumber keempat adalah yang dilakukan oleh Desri J.Angio (2014), yang berjudul "Kreativitas Guru dalam Menerapkan Media Audio Visual pada Pembelajaran IPA di SDN Bualemo Kabupaten Gorontalo Utara”. Dalam penelitian ini, peneliti menggunakan pendekatan deskriptif kualitatif. Berdasarkan hasil penelitian tersebut diketahui bahwa terbatasnya pengetahuan guru menggunakan media audio visual merupakan faktor penghambat kreatifitas guru dalam menggunakan media tersebut. Pada proses pembelajaran guru hanya menjelaskan materi melalui gambar yang ditampilkan saja tanpa mendesain materinya agar menarik minat belajar siswa, akibatnya sebagian siswa kurang memperhatikan materi yang diajarkan dan guru tidak memberikan kesempatan kepada siswa untuk aktif dan kritis bermaksud memberikan kesempatan bertanya sehingga itu akan berpengaruh pada siswa dan yang pasti tidak dapat membangkitkan hasil belajar siswa. 
Sumber kelima adalah yang dilakukan oleh Yona Syaida Oktira (2013), yang berjudul "Penggunaan Media Audio Visual untuk Meningkatkan Kemandirian Siswa Belajar Seni Budaya". Dalam penelitian ini, penulis menggunakan metode deskriptif yang bersifat kualitatif. Berdasarkan hasil penelitian tersebut diketahui bahwa media audio visual telah berhasil membangkitkan ketertarikan siswa untuk mempelajari seni budaya. Rasa ketertarikan telah membangkitkan rasa kemandirian siswa itu sehingga patisipasi aktif siswa dalam proses pembelajaran juga mengingkatkan dengan sendirinya. Kemandirian siswa terlihat dari beberapa indikator keinginan, perhatian, disiplin, partisipasi itu maka perlu membangkitkan kemandirian. Cara membangkitkan kemandirian adalah dengan cara menggunakan media audio visual sebagai alat penunjang kemandirian siswa terhadap pembelajaran seni budaya.

Penelitian diatas merupakan penelitian terdahulu yang sudah dilakukan berhubungan dengan media audio visual. Penelitian pertama meneliti tentang motivasi belajar siswa setelah menggunakan media audio visual. Kedua meneliti tentang peningkatan kemampuan bernyanyi siswa setelah menggunakan media audio visual. Ketiga meneliti tentang peningkatan hasil belajar setelah menggunakan media audio visual. Keempat meneliti tentang kreativitas guru menggunakan media audio visual. Kelima meneliti tentang kemandirian belajar siswa dalam penggunaan media audio visual. Berbagai penelitian tentang media audio visual penliti tertarik untuk membahas kembali penelitian tentang media audio visual dengan membahas proses penggunaan media audio visual. 


\subsection{Landasan Teoreris}

\subsubsection{Belajar dan Mengajar}

Kegiatan dalam belajar mengajar, peserta didik mempunyai latar belakang yang berbeda-beda, seperti lingkungan sosial, lingkungan budaya, gaya belajar, keadaan ekonomi dan tingkat kecerdasan pesert didik. Dalam proses belajar-mengajar jika prosesnya terarah maka akan meningkatkan kualitas manusia secara utuh, meliputi kognitif intelektual, ketrampilan, dan nilai-nilai. Maka untuk lebih jelas peneliti akan membagi pengertian belajar dan mengajar sebagai berikut :

\subsubsection{Belajar}

Belajar pada hakikatnya adalah ada suatu perubahan yang terjadi pada diri seseorang setelah melakukan aktivitas tertentu (Pupuh dan Sobry 2007 : 6). Dalam belajar yang terpenting adalah adanya sebuah proses bukan hanya hasil yang diperoleh dalam belajar. Menurut Sudarwan (2013 : 47) teori belajar berhubungan dengan cara individu belajar, penting untuk menjelaskan, memprediksi serta mengontrol proses atau kegiatan belajar. Teori belajar juga berhubungan dengan kondisi belajar, motivasi belajar serta kapabilitas siswa dan teori belajar memandang kegiatan belajar dari sudut siswa.

Banyak definisi para ahli tentang belajar, diantaranya yaitu menurut Hilgard \& Bower dalam bukunya Theories of Learning (1975) mengemukakan bahwa belajar berhubungan dengan perubahan sikap seseorang terhadap suatu kejadian tertentu yang disebabkan dari pengalaman seseorang tersebut secara berulag-ulang, dimana perubahan tersebut tidak bisa dijelaskan atau 
kecenderungan keterbiasaan. M. Sobry Sutikno dalam bukunya Menuju Pendidikan Bermutu (2004), mengartikan belajar adalah seseorang untuk memperoleh suatu perubahan yang baru dari proses usaha yang dilakukan untuk hasil pengalaman sendiri dalam interaksi dengan lingkungannya. Sedangkan menurut Thursan Hakim dalam bukunya Belajar Secara Efektif (2002), mengartikan belajar adalah suatu proses perubahan dalam kepribadian manusia, dan perubahan tersebut ditampakkan seperti peningkatan kecakapan, pengetahuan, sikap, kebiasaan, pemahaman, ketrampilan, daya fikir, dan lain-lain kemampuannya.

Dalam ilmu psikologi pendidikan (Achmad rifa'i dan Catharina 2012 : 66), konsep tentang belajar telah banyak didefinisikan oleh para pakar psikologi. Gage dan Berliner (1983 : 252) menyatakan belajar merupakan berubahnya perilaku seseorang dari beberapa proses karena hasil dari pengalaman. Morgan et.al. (1986 : 140) menyatakan belajar merupakan perubahan yang terjadi karena hasil dari praktik atau pengalaman secara relatif stabil. Slavin (1994: 152) menyatakan belajar merupakan perubahan yang disebabkan oleh pengalaman dari diri seseorang. Berikut merupakan ciri-ciri perubahan dalam pengertian belajar menurut Slameto (2003 : 3) meliputi: (a) Perubahan yang terjadi berlangsung secara sadar, dari pengetahuannya, sikapnya, kecakapannya, dan lain-lain; (b) Perubahan dalam belajar bersifat kontinyu dan fungsional setiap hasil belajar memiliki makna dan guna yang praktis; (c) Perubahan belajar bersifat positif dan aktif, senantiasa menuju perubahan yang lebih baik; (d) Perubahan dalam belajar bukan bersifat sementara, bukan hasil belajar jika perubahan itu hanya sesaat, 
seperti berkeringat, bersin, dan lain-lain; (e) Perubahan dalam belajar bertujuan dan terarah karena seseorang hendaknya sudah menyadari apa yang akan berubah pada dirinya melalui belajar; (f) Perubahan mencakup seluruh aspek tingkah laku, bukan bagian-bagian tertentu secara parsial.

\subsubsection{Mengajar}

Mengajar merupakan suatu perbuatan yang kompleks, perbuatan mengajar yang kompleks dapat diterjemahkan sebagai penggunaan secara integratif secara komponen yang terkandung dalam perbuatan mengajar itu untuk menyampaikan pesan pengajaran (Pupuh dan Sobry 2007 : 8). Teori mengajar berhubungan dengan aktivitas mengajar, tujuan dari pengajaran dan kemampuan mengajar serta kondisi saat mengajar (Sudarwan 2013 : 47).

Bohar Suharto (1997) mendefinisikan, mengajar merupakan suatu aktivitas mengorganisasi atau mengatur lingkungan sehingga tercipta suasana yang sebaik-baiknya dan menghubungkannya dengan peserta didik sehingga terjadi proses belajar yang menyenangkan. Sementara Oemar hamalik (1992) mendefinisikan, mengajar sebagai proses menyampaikan pengetahuan dan kecakapan kepada siswa. Sedangkan dalam pengertian lain, Davies (1971) juga menjelaskan bahwa mengajar adalah suatu aktivitas profesional yang memerlukan ketrampilan tingkat tinggi dan menyangkut pengambilan keputusan.

Menurut Sudarwan Darnim (2013 : 34) mendefinisikan mengajar sebagai suatu proses mengorganisasi atau menata sejumlah sumber potensi secara baik dan benar sehingga terjadi proses belajar anak. Berhasil tidaknya pencapaian tujuan mengajar dirancang dan dijalankan secara profesional. Dan setiap kegiatan 
pengajaran pasti melibatkan siswa dan guru, karena pencipta kondisi belajar yang didesain secara sengaja, sistematis dan berkesinambungan adalah seorang guru. Dengan tujuan pengajaran untuk mencapai anak didik secara aktif dalam pembelajaran. Untuk itu perlu adanya sebuah metode mengajar yang umum dalam proses belajar mengajar di kelas antara lain :

a) Metode Ceramah

Ceramah diartikan sebagai proses penyampaian informasi dengan jalan mengeksplanasi atau menuturkan sekelompok materi secara lisan dan pada saat yang sama materi itu diterima oleh sekelompok subjek.

b) Metode Diskusi

Diskusi diartikan sebagai suatu proses penyampaian materi, di mana guru bersama subjek didik mengadakan dialog bersama untuk mencari jalan pemecahan dan penyerap serta menganalisis satu atau sekelompok meteri tertentu.

c) Metode Tugas

Tugas diartikan sebagai materi tambahan yang harus dipenuhi oleh subjek didik, baik di dalam maupun di luar kelas.

d) Metode Demonstrasi

Metode demonstrasi sangat cocok diterapkan dalam pembelajaran dikarenakan siswa dapat melihat langsung proses terjadinya sesuatu. Metode demonstrasi adalah sebuah cara dalam bahan pelajaran dengan cara melakukan sebuah praktek suatu proses kepada siswa, menyajikan benda 
yang sedang dipelajari baik benda sebenarnya maupun tiruan dengan penjelasan secara lisan.

e) Metode Tanya Jawab

Metode tanya jawab merupakan proses penyampaian guru melakukan kegiatan bertanya dan murid menjawabnya begitu juga sebaliknya. Metode ini terdapat kekurangan dan kelebihan, sehingga guru harus menyesuaikan meteri pelajaran dengan metode tanya jawab.

\subsubsection{Media Pembelajaran}

\subsubsection{Pengertian Media}

Menurut Martin dan Briggs (1986), media adalah segala sumber yang digunakan untuk melakukan sebuah komunikasi dengan siswa. Contoh dari media bisa berupa perangkat keras seperti komputer, televisi, proyektor, dan perangkat lunak yang ada didalam perangkat keras tersebut. Menurut Degeng, media pembelajaran adalah komponen strategi penyampaian yang dapat memberikan pesan kepada siswa saat penyampaiannya, baik berupa orang, alat, ataupun bahan (Made Wena, 2009 : 9).

Gearlach \& Ely (dalam Sanjaya, 2012 : 65) mengatakan bahwa media apabila dipahami secara garis besar adalah manusia, materi atau kejadian yang membangun suatu kondisi yang membuat siswa mampu memperoleh pengetahuan, ketrampilan atau sikap. Sedangkan menurut Atwi Suparman (1997) mendefinisikan, media merupakan alat yang digunakan untuk menyalurkan pesan atau informasi dari pengirim kepada penerima pesan. Secara lebih khusus, 
pengertian media dalam proses belajar mengajar lebih cenderung dimaknai sebagai alat-alat untuk menangkap, memproses dan menyusun kembali informasi.

\subsubsection{Fungsi Media}

Media memiliki tujuan untuk menjelaskan beberapa hal yang penting dan menunjukkan hal-hal yang tersembunyi. Kesulitan dalam mempersiapkan bahan ajar dapat dibantu denan adanya media sebagai perantara. Berikut merupakan fungsi dari media menurut Nana Sudjana (1991) seperti yang dikutip oleh Pupuh Fathurrohman dan M. Sobry Sutikno $(2010 ; 66)$ yakni :

a) Penggunaan media dalam proses belajar mengajar mempunya fungsi untuk membuat situasi dalam proses pembelajaran menjadi efektif, sehingga penggunaan media bukan merupakan fungsi tambahan.

b) Penggunaan media pengajaran merupakan bagian yang integral dari keseluruhan situasi mengajar, maka media harus menjadi salah satu alat untuk digunakan dan dikembangkan oleh guru.

c) Media dalam pengajaran, penggunaannya bersifat integral dengan tujuan dan isi pembelajaran.

d) Penggunaan media dalam pengajaran bukan semata-mata sebagai alat hiburan yang digunakan hanya sekedar melengkapi proses belajar supaya lebih menarik perhatian siswa.

e) Penggunaan media dalam pengajaran lebih diutamakan untuk membantu siswa dalam menangkap pengertian yang diberikan guru secara cepat dalam proses belajar mengajar. 
f) Penggunaan media dalam pengajaran diutamakan utnuk memperbaiki mutu dalam proses belajar mengajar.

Menurut Ahmad Sudrajad (2008) (dikutip Chamdani Lukman 2013 : 9-10) Media memiliki beberapa fungsi, di antaranya:

a) Media pembelajaran dapat mengatasi keterbatasan pengalaman yang dimiliki oleh para peserta didik.

b) Media pembelajaran dapat melampaui batasan ruang kelas

c) Media pembelajaran memungkinkan adanya interaksi langsung antara peserta didik dengan lingkungannya.

d) Media menghasilkan keseragaman pengamatan

e) Media dapat menanamkan konsep dasar yang benar, konkret, dan realistis.

f) Media membangkitkan keinginan dan minat baru.

g) Media membangkitkan motivasi dan merangsang anak untuk belajar.

h) Media memberikan pengalaman yang integral/menyeluruh dari yang konkret sampai dengan abstrak

\subsubsection{Media Audio Visual}

Media audio visual adalah media yang penyampaian pesannya dapat diterima oleh indra pendengar dan indra penglihatan, akan tetapi hasil gambar yang dihasilkannya adalah gambar diam atau memiliki unsur gerak (Chamdani 2013 : 11). Beberapa kelebihan media audio visual dapat memperjelas penyajian pesan agar tidak terlalu bersifat verbalistis (dalam bentuk kata-kata, tertulis atau lisan belaka), mengatasi perbatasan ruang, waktu dan daya indra, media audio visual bisa berperan dalam pembelajaran tutorial. 
Pengertian media audio visual diartikan sendiri-sendiri maka pengertian media audio adalah segala macam bentuk media yang berkaitan dengan indera pendengaran, termasuk dalam kelompok media audio. Media audio dalam pengertian lain yaitu penyajian pengajaran atau pengetahuan melalui pendidikan audio atau pengalaman mendengar (Hujair 2013 : 106-107). Jenis-jenis alat yang di kategori dalam media audio yaitu seperti audio kaset, piringan hitam, labotarium bahasa dan radio. Media audio adalah segala macam betuk media yang berkaitan dengan indera pendengaran, termasuk dalam kelompok media audio (Hujair, 2013 : 06). Karena media audio berkaitan dengan indera pendengaran, maka pesan yang akan disampaikan dituangkan ke dalam lambang-lambang auditif, baik verbal (kata-kata atau bahasa lisan) maupun non verbal.

Media audio visual mempunyai tujuan pembelajaran sebagai alat bantu dalam proses belajar-mengajar yaitu untuk : (1) mempermudah proses pembelajaran di kelas; (2) meningkatkan efisiensi proses pembelajaran; (3) menjaga relevasi antara meteri pelajaran dengan tujuan belajar; (4) membantu konsentrasi pembelajaran dalam proses pembelajaran (Hujair Sanaky, 2013 : 5). Didalam penggunaannya media audio visual mempunyai efektivitas tersendiri dari media pembelajaran lainnya. Jadi efektivitas tidak hanya dipandang pencapaian tujuan yang berhasil saja, tetapi kepuasan seseorang juga perlu di pertimbangkan. Untuk itu efektivitas menurut Robbins (1997) juga dapat dilihat dari tingkat kepuasan yang dicapai oleh orang (Daryanto, 2011 : 34). Efektivitas dalam buku media pembelajaran, Daryanto (2011 : 34) menjelaskan bahwa efktivitas merupakan suatu konsep yang sangat penting karena mampu memberikan 
gambaran mengenai suatu keberhasilan dalam mencapai sasaran atau tujuan yang telah direncanakan (Prokopenko, 1987), atau tingkat pencapaian tujuan (Hoy dan Miskel, 1992). Jadi jika peneliti dapat menyimpulkan dari pendapat para ahli efektivitas adalah tingkat keberhasilan dengan pencapaian tujuan atau sasaran dengan pertimbangan kepuasan seseorang. Dalam penjelasan di atas dapat diketahui aspek-aspek efektivitas pembelajaran saat menggunakan media audio visual diantaranya : (1) peningkatan pengetahuan; (2) peningkatan ketrampilan; (3) perubahan sikap; (4) perilaku; (5) kemampuan adaptasi; (6) peningkatan integrasi; (7) peningkatan partisipasi; dan (8) peningkatan interaksi kultural.

Selain efektivitas, media audio visual juga mempunyai efisiensi dalam penggunakan media pembelajaran dalam proses belajar mengajar. Sedangkan pengetian efisiensi adalah sesuatu yang kita kerjakan berkaitan dengan menghasilkan hasil yang optimal dengan tidak membuang banyak waktu dalam proses pengerjaannya. Efisiensi sendiri mempunyai 2 unsur yaitu kegiatan dan hasil kegiatan itu sendiri. Jika penulis dapat menyimpulkan maka efisiensi media audio visual yaitu kegiatan pembelajaran yang berbantu media audio visual yang menghasilkan hasil yang optimal dengan tidak membuang banyak waktu dalam proses pembelajaran.

\subsubsection{Pembelajaran Seni Budaya (Seni Musik)}

\subsubsection{Pengertian Pembelajaran}

Pembelajaran menurut Briggs (1992) menjelaskan bahwa pembelajaran adalah perangkat peristiwa yang mempengaruhi peserta didik sedemikian rupa 
sehingga peserta didik itu memperoleh kemudahan dalam berinteraksi berikutnya dengan lingkungan. Menurut Gagne (1981) menyatakan bahwa pembelajaran merupakan serangkaian peristiwa eksternal peserta didik yang dirancang untuk mendukung proses internal belajar (Achmad rifa'i dan Catharina 2012 : 158-159). Pembelajaran merupakan suatu sistem, yang terdiri atas berbagai komponen yang saling berhubungan satu dengan yang lain. Komponen tersebut meliputi : tujuan, materi, metode, dan evaluasi. Komponen tersebut harus diperhatikan guru dalam memilih dan menentukan model-model pembelajaran untuk digunakan dalam kegiatan pembelajaran. Ada beberapa hal yang harus diperhatikan dalam pembelajaran yaitu tahapan pembelajaran yang akan dijelaskan sebagai berikut.

(1) Tahap Perencanaan Pembelajaran

Tahap perencanaan pembelajaran merupakan tahap yang sangat penting dalam setiap proses pembelajaran. Dikatakan penting karena tahap perencana ini sangat mempengaruhi kualitas hasil pembelajaran. Tahap perencanaan pembelajaran adalah tahap yang akan berhubungan dengan kemampuan guru menguasai bahan ajar (Rusman, 2013 : 75). Perencanaan proses pembelajaran meliputi Silabus dan Rencana Pelaksanaan Pembelajaran (RPP).

(a) Silabus

Silabus sebagai acuan pengembangan Rencana Pelaksanaan Pembelajaran memuat identitas mata pelajaran atau tema pembelajaran, standar kompetensi, kompetensi dasar, materi pembelajaran, kegiatan pembelajaran, indikator pencapaian kompetensi, penilaian, alokasi waktu,dan sumber belajar. 
(b) Rencana Pelaksanaan Pembelajaran (RPP)

Rencana Pelaksanaan Pembelajaran dijabarkan dari silabus untuk mengarahkan kegiatan belajar siswa dalam upaya mencapai kompetensi dasar. Komponen-komponen yang ada dalam RPP yaitu (1) Identitas Mata Pelajaran; (2) Standar Kompetensi; (3) Kompetensi Dasar; (4) Indikator Pencapaian Kompetensi; (5) Tujuan Pembelajaran; (6) Materi Ajar; (7) Alokasi Waktu; (8) Metode Pembelajaran; (9) Kegiatan Pembelajaran; (10) Penelitian Hasil Belajar; (11) Sumber Belajar.

(2) Tahap Pelaksanaan Proses Pembelajaran

Pelaksanaan pembelajaran merupakan implementasi dari Rencana Pelaksanaan Pembelajaran. Pelaksanaan pembelajaran meliputi :

(a) Kegiatan Pendahuluan/Pembuka

Menurut Mansor, dkk (2012) guru yang telah melaksanakan membuka pemebelajaran dapat membantu menciptakan pemebelajaran yang efektif di kelas. Perlunya melaksanakan membuka pelajaran juga disampaikan oleh Ojukwu (2014) yang menyatakan bahwa pada setiap pembelajaran guru harus membuka pelajaran untuk memperkenalkan hal-hal yang akan dipelajari agar siswa memiliki ketertarikan, merasa ingin tau dan memiliki kemauan untuk mempelajari materi (Khakiim 2016). Kegiatan pendahuluan/pembuka guru harus memerhatikan halhal berikut : (1) menyiapkan peserta didik secara psikis dan fisik untuk mengikuti proses pembelajaran; (2) mengajukan pertanyaan-pertanyaan yang mengaitkan pengetahuan sebelum dengan materi yang akan dipelajari; (3) menjelaskan tujuan 
pembelajaran atau kompetesi dasar yang akan dicapai; (4) menyiapkan cakupan materi dan penjelasan uraian kegiatan sesuai silabus (Rusman 2013 : 10).

(b) Kegiatan Inti

Kegiatan inti merupakan proses pembelajaran untuk mencapai kompetensi dasar yang dilakukan secara interaktif, inspiratif, menyenangkan, menantang, memotivasi siswa untuk berpartisipasi aktif, serta memberikan ruang yang cukup bagi prakarsa, kreativitas, dan kemandirian sesuai dengan bakat, minat dan perkembangan fisik serta psikologis peserta didik (Rusman 2013 : 11). Kegiatan inti menggunakan metode yang disesuaikan dengan siswa dan mata pelajaran, yang dapat meliputi proses eksplorasi, elaborasi dan konfirmasi.

- Eksplorasi

Kegiatan eksplorasi, guru harus memerhatikan hal-hal berikut : (1) melibatkan peserta didik mencari informasi yang luas dan dalam tentang topik/tema materi yang akan dipelajari dengan menerapkan prinsip "alam takambang” jadi guru dan belajar dari aneka sumber; (2) menggunakan beragam pendekatan pembelajaran, media pembelajaran, dan sumber belajar lain; (3) memfasilitasi terjadinya interaksi antarpeserta didik serta antara peserta didik dengan guru, lingkungan, dan sumber belajar lainnya; (4) melibatkan peserta didik secara aktif dalam setiap kegiatan pembelajaran; (5) memfasilitasi peserta didik melakukan percobaan di laboratorium, studio, atau lapangan.

- Elaborasi

Kegiatan elaborasi, guru harus memperhatikan hal-hal berikut : (1) membiasakan peserta didik membaca dan menulis yang beragam melalui tugas-tugas tertentu 
yang bermakna; (2) memfasilitasi peserta didik melalui pemberian tugas, diskusi, dan lain-lain untuk memunculkan gagasan baru baik secara lisan maupun tertulis; (3) memberi kesempatan untuk berfikir, menganalisis, menyelesaikan masalah, dan bertindak tanpa rasa takut; (4) memfasilitasi peserta didik dalam pembelajaran koorperatif dan kolaboratif; (5) memfasilitasi peerta didik berkompetensi secara sehat untuk meningkatkan prestasi belajar; (6) memfasilitasi peserta didik membuat laporan eksplorasi yang dilakukan baik lisan maupun tertulis, secara individual maupun kelompok; (7) memfasilitasi peserta didik untuk meyajikan hasil kerja individual maupun kelompok; (8) memfasilitasi peserta didik melakukan pameran, turnamen, festival, serta produk yang dihasilkan; (9) memfasilitasi peserta didik melakukan kegiatan yang menumbuhkan kebangsaan dan rasa percaya diri peserta didik.

- Konfirmasi

Kegiatan konfirmasi, guru harus memperhatikan hal-hal berikut : (1) memberikan umpan balik positif dan penguatan dalam bentuk lisan, tulisan, isyarat, maupun hadiah terhadap keberhasilan peserta didik; (2) memberikan konfimasi terhadap hasil eksplorasi dan elaborasi peserta didik melalui berbagai sumber; (3) memfasilitasi peserta didik melakukan refleksi untuk memperoleh pengalaman belajar yang telah dilakukan; (4) memfasilitasi peserta didik untuk memperoleh pengalaman yang bermakna dalam mencapai kompetensi dasar; (5) berfungsi sebagai narasumber dan fasilitator dalam memjawab pertanyaan peserta didik yang menghadapi kesulitan, dengan menggunakan bahasa yang baku dan benar; (6) membantu menyelesaikan masalah; (7) memberi acuan agar peserta didik 
dapat melakukan pengecekan hasil eksplorasi; (8) memberi informasi untuk bereksplorasi lebih jauh; (9) memberikan motivasi kepada peserta didik yang kurang atau belum berpartisipasi aktif.

(c) Kegiatan Penutup

Menurut Widodo, dkk (2007) saat menutup pelajaran terdapat kegiatan untuk meninjau kembali materi yang dipelajari dan penguatan yang disampaikan guru, hal tersebut diperlukan siswa untuk membimbing siswa membangun gambaran tentang keseluruhan meteri yang telah dipelajari agar lebih mudah diingat. Ojukwu (2014) juga berpendapat bahwa pada setiap pembelajaran guru perlu melaksanakan menutup pelajaran untuk memberikan penekanan padahal-hal penting dari pembelajaran lebih bermakna (Khakiim 2016). Dalam kegiatan penutup, guru harus memperhatikan hal-hal berikut : (1) bersama-sama dengan peserta didik dan/atau sendiri membuat rangkuman/ kesimpulan pelajaran; (2) melakukan penilaian dan/atau reflesi terhadap kegiatan yang sudah dilaksanakan secara konsisten dan terprogram; (3) memberikan umpan balik terhadap proses dan hasil pembelajaran; (4) merencanakan kegiatan tindak lanjut dalam bentuk pembelajaran remidi, program pengayaan, layanan konseling dan/atau memberikan tugas, baik tugas individual maupun kelompok sesuai dengan hasil belajar peserta didik; (5) menyampaikan rencana pembelajaran pada pertemuan berukutnya.

(3) Evaluasi Pembelajaran

Menurut Rusman (2013 : 14) dalam buku "Model-Model Pembelajaran" menjelaskan bahwa evaluasi pembelajaran dilakukan untuk menentukan kualitas 
pembelajaran secara keseluruhan, mencakup tahap perencanaan proses pembelajaran, pelaksanaan proses pembelajaran, dan penilaian hasil pembelajaran. Evaluasi proses pembelajaran diselenggarakan dengan cara : (a) membandingkan proses pembelajaran yang dilaksanakan guru dengan standar proses; (b) mengidentifikasi kinerja guru dalam proses pembelajaran sesuai dengan kompetensi guru. Evaluasi proses pembelajaran juga memusatkan pada keseluruhan kinerja guru dalam proses pembelajaran.

\subsubsection{Pembelajaran Seni Musik}

Menurut Sulisdiyanto(2012) pembelajaran musik adalah pembelajaran tentang kemampuan bermusik dengan didasarkkan kepada fundasi pada bermusik (sense of music). Rasa irama, nada dan harmoni merupakan tanda rasa bermusik yang tumbuh. Lagu dan komposisi merupakan hal yang pertama yang harus di pahami dalam pengembangan kemampuan bermusik. Unsur musik yang dikembangkan antara lain : teknik dasar bernyanyi, irama, melodi, harmoni, bentuk atau struktur lagu, serta ekspresi.

Kegiatan bernyanyi adalah merupakan kegiatan yang menyenangkan bagi anak, dan pengalaman bernyanyi ini memberikan kepuasan kepadanya (Jamalus 1088 : 46). Bernyanyi juga merupakan alat bagi anak untuk mengungkapkan pikiran dan perasaannya. Oleh sebab itu kegiatan bernyanyi sangat penting bagi kegiatan di sekolahan. Cara belajar bernyanyi anak-anak bermulai dari meniru, seperti belajar berbicara. Karena anak sangatlah senang sekali meniru apa yang 
dia liat dan didengar. Memang sangat menakjubkan sekali alat suara manusia, karena bisa meniru bermacam-macam bunyi yang ada di sekelilingnya.

Jika ingin bernyanyi dengan baik, maka harus mempelajari dasar-dasar teknik bernyanyi yang mencangkup sikap badan, pernafasan, pembentukan suara, pengucapan, dan resonansi. Dalam sikap badan yang baik untuk bernyanyi adalah sebagai berikut : 1) duduklah di kursi atau bangku sedikit ke pinggir bagian depan dengan bobot badan bertumpu pada bagian bawah tulang pinggul yang dinamakan bonggol tulang duduk, 2) tarik dan regangkanlah tulang pinggang sehingga tegak lurus, dan otot perut agak dikencangkan sehingga tidak kendur dan tangan diletakkan di atas paha atau diatas daun meja, tanpa tegangan, 3) dada agak dibusungkan sehingga tulang rusuk terangkat, dan rongga dada akan bertambah besar, 4) tarik dan regangkanlah tulang tengkuk sehingga leher tegak lurus, dan posisi kepala juga lurus dengan pandangan lurus ke depan. Biasanya seorang penyanyi harus berdiri saat bernyanyi dan dengan berdiri gerakan badan akan lebih bebas saat bernyanyi. Cara berdiri yang baik ialah dengan agak memutar persendian tulang paha, lutut, dan pergelangan kaki ke arah luar sehingga ke dua kaki membentuk sudut kira-kira 30 derajat dengan agak merenggangkan kedua tumit.

Pernafasan merupakan hal penting dalam melakukan kegiatan bernyanyi, dalam pernafasan ini terdapat kerjasama otot-otot badan, yaitu otot dada, otot perut, dan sekat rongga badan atau diafragma. Ada tiga macam pernafasan yang sering dilakukan saat bernyanyi yaitu pernafasan dada, pernafasan perut, pernafasan diafragma. Tiga macam pernafasan tersebut yang paling cocok adalah 
pernafasan diafragma, karena pernafasan ini sangat kuat menahan tekanan, sehingga paru-paru yang penuh udara tadi tidak tegang. Pernafasan diafragma ini bisa kuat dikarenakan bukan hanya otot diafragma yang bekerja, tetapi otot dada dan otot perut juga. Selain pernafasan pembentukan suara dan pengucapan saat bernyanyi juga harus diperhatikan, karena hal ini mempengaruhi dengan jelas atau tidaknya saat bernyanyi. Hal tersebut biasa disebut dengan artikulasi, yang diartikan cara pengucapan kata demi kata yang baik dan jelas (Kemdikbud 2014 : $35)$.

Dalam mempelajari musik sangatlah perlu untuk mempelajari teori musik dasar yang terdiri dari irama, melodi, harmoni, bentuk/struktur lagu dan ekspresi. Yang pertama yaitu irama, menurut Jamalus (1988: 7-8) mengemukakan bahwa irama ialah urutan rangkaian gerak yang menjadi unsur dasar dalam musik dan tari. Irama dalam musik terbentuk dari sekelompok bunyi dan diam dengan bermacam-macam lama waktu atau panjang pendeknya, membentuk pola irama, begerak menurut pulsa dalam ayunan birama. Pengertian irama menurut Wagiman joseph dibuku teori musik 1 menjelaskan bahwa unsur pokok musik yang terbentuk dari sekelompok bunyi dan diam dengan panjang pendek yang berbeda lama waktunya. Secara singkat irama adalah pola panjang pendek bunyi dalam lagu. Irama secara populer adalah adanya unsur-unsur dalam musik sebagai pembagian berlangsungnya waktu yang memberi pernyataan hidup kepada musik. Dari beberapa teori di atas, dapat dikatakan bahwa irama adalah urutan rangkaian gerak yang membentuk pola irama dan bergerak tertatur sehingga menyebabkan lagu enak didengar dan dirasakan. 
Unsur pokok musik yang kedua adalah melodi dan menurut Jamalus (1988 : 16) melodi adalah susunan rangkaian nada yang terdengar berturutan serta berirama, dan mengungkapkan suatu gagasan. Menurut Wagiman Joseph di buku teori musik 1 bahwa melodi memiliki unsur irama dan irama memiliki unsur pulsa, birama, dan panjang pendek bunyi. Selain irama ada unsur lain yaitu nada, jadi singkatnya melodi memiliki 2 unsur pokok yaitu irama dan nada. Dari pengertian-pengertian tersebut, dapat dikatakan bahwa melodi merupakan rangkaian nada-nada yang memiliki ketetarturan, yang disusun secara ritmis yang mengungkapkan seuatu perasaan dan pikiran.

Unsur pokok musik yang ketiga yaitu harmoni dan menurut Jamalus (1988 : 30) menjelaskan harmoni ialah bunyi gabungan dua nada atau lebih, yang berbeda tingginya dan kita dengar serentak, harmoni juga bisa disebut dengan paduan nada. Dasar dari paduan nada ialah trinada atau akor yang bisa diartikan gabungan tiga nada yang terbentuk dari salah satu nada dengan nada terts dan kuinnya, atau dikatakan terts tersusun. Pendapat diatas dapat ditangkap secara sederhana yaitu bahawa harmoni adalah paduan nada-nada yang apabila dibunyikan secara bersama-sama akan menghasilkan keselarasan bunyi.

Unsur musik selanjutnya yaitu bentuk lagu/struktur lagu, menurut Jamalus (1988 : 35) menjelaskan bentuk lagu/struktur lagu ialah susunan serta hubungan antara unsur-unsur musik dalam suatu lagu sehingga menghasilkan suatu komposisi atau lagu yang bermakna. Unsur musik yang terakhir yaitu ekspresi, dan unsur-unsur ekspresi dalam musik meliputi tempo atau tingkat kecepatan musik, dinamika atau tingkat volume suara atau keras lunaknya suara, 
dan warna nada yang tergantung dari bahan sumber suara, serta gaya atau cara memproduksi nadanya. Maka menurut Jamalus (1988 : 38) ekspresi dalam musik ialah ungkapan pikiran dan perasaan yang mencangkup semua nuansa dari tempo, dinamika, dan warna nada dari unsur-unsur pokok musik, dalam pengelompokan frase yang diwujudkan oleh seniman musik atau penyanyi, disampaikan kepada pendengarnya.

\subsection{Kerangka Berfikir}

Berdasarkan kajian pustaka yang telah diuraikan diatas, peneliti menyusun kerangka berpikir dalam penyusunan penelitian ini. Pada penyusunan kerangka berpikir, dalam penelitian ini dapat disimpulkan bahwa guru dan siswa melakukan kegiatan belajar mengajar dalam proses pembelajaran seni budaya sub materi musik. Pembelajaran seni budaya sub materi musik guru menerapkan media pembalajaran dalam proses penyampaikan materi kepada siswa. Media pembelajaran yang digunakan yaitu media audio visual, guru memilih media ini dikarenakan media audio visual sangat tepat untuk digunakan dalam pembelajaran seni budaya. Penggunaan media audio visual dalam pembelajaran seni budaya sub materi musik bertujuan supaya hasil dalam proses belajar mengajar menjadi lebih efektif dan efisien. 


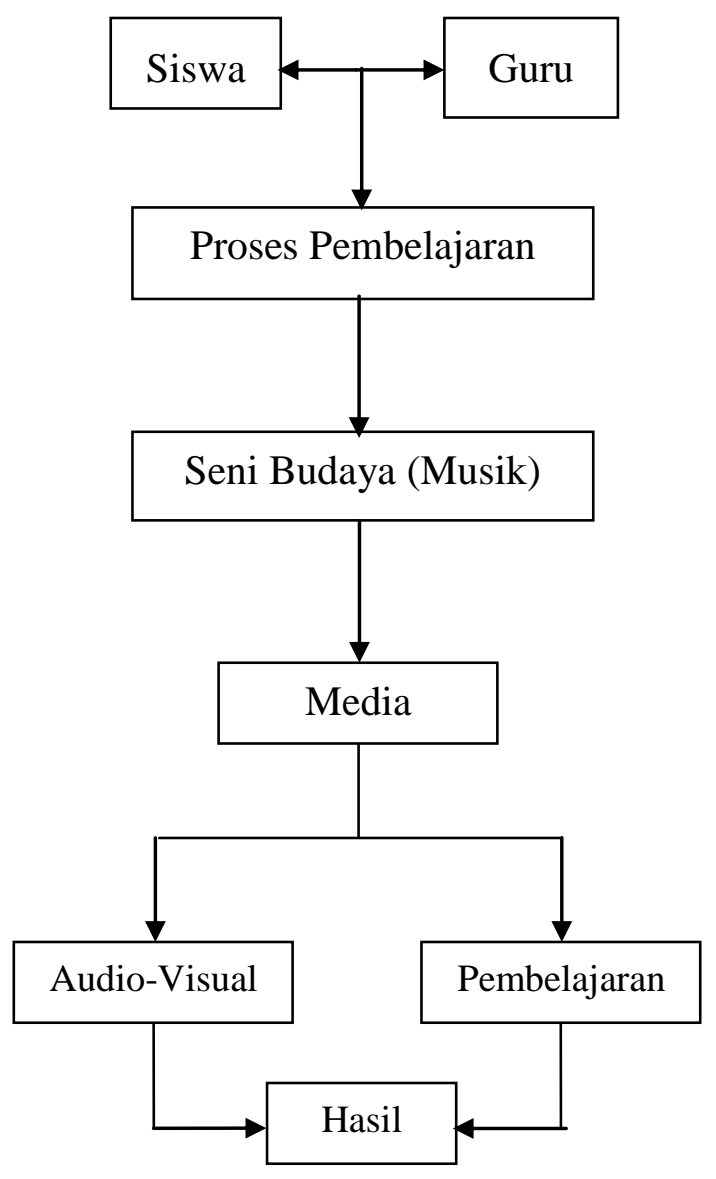

Bagan 2.1

Skema Kerangka Berfikir

(Sumber: Angga Dwi W. 4 Maret 2017) 


\section{BAB III}

\section{METODE PENELITIAN}

\subsection{Pendekatan Penelitian}

Peneliti menggunakan pendekatan pembelajaran musikologi yang dijelaskan sebagai berikut :

\subsubsection{Pendekatan Pembelajaran}

Ada beberapa pengertian dalam pendekatan pembelajaran, adapun pengertian pendekatan pembelajaran antara lain sebagai sudut pandang untuk pedoman untuk memilih model, metode dan teknik pembelajaran. Pendekatan pembelajaran juga dapat diartikan sebagai titik tolak terhadap proses pembelajaran, yang menjurus kepada terjadinya kejadian yang sifatnya masih sangat umum, didalamnya mewadahi, menginspirasi, menguatkan metode pembelajaran.

Menurut Sanjaya (2008 : 127) pendekatan dapat diartikan sebagai titik tolak atau sudut pandang kita terhadap proses pembelajaran. Roy Kellen (1998) dalam Rusman (2013 : 380) mencatat bahwa terdapat dua pendekatan dalam pembelajaran, yaitu pendekatan yang terpusat pada guru (teacher-centered approaches) dan pendekatan yang berpusat pada siswa (student-centered approaches)

\subsubsection{Pendekatan Musikologi}

Pengertian musikologi merupakan ilmu tentang musik, sejarah musik dan perkembangan musik. Menurut Ha Lang dan L.Harp dalam Harvard Dictionary 
of Music tulisan Willi Apel (1965), berpendapat bahwa musikologi menyatukan dalam domain-domainnya seluruh ilmu yang menyangkut produksi, rupa, dan aplikasi dari fenomena fisik bunyi. Jadi pendekatan musikologi bisa diartikan sebagai proses mempelajari seluruh ilmu yang berhubungan dengan produksi, rupa, aplikasi dari fenomena fisik bunyi, sejarah dan perkembangan musik.

\subsection{Metode Penelitian}

Penilitian ini menggunakan metode kualitatif. Hal ini dimaksud agar dalam penelitian ini, hasil penelitian digambarkan dan dijelaskan dengan menggunakan kalimat-kalimat bukan dengan angka-angka. Sesuai dengan pemahaman kualitatif adalah suatu pendekatan atau penelusuran untuk mengeksplorasi dan memahami suatu gejala sentral ( Raco, 2010 : 7 ). Penelitian ini juga bersifat deskriptif kualitatif yang menggambarkan atau menguraikan permasalahan yang berhubungan dengan keadaann atau status fenomena kelompok tertentu dalam bentuk kalimat, bukan dengan angka-angka. Data yang diperlukan penelitian kualitatif diperoleh dari berbagai narasumber yang memberikan informasi tentang data. Dalam penelitian ini, peneliti berusaha mencari data bersifat kualitatif mengenai penggunaan media audio visual dalam pembelajaran seni budaya sub materi musik di SMK Negeri 03 Salatiga. Suatu penelitian agar memperoleh hasil yang sesuai dengan yang diharapkan, diperlukan metode penelitian yang dapat dipertanggung jawabkan secara ilmiah. 


\subsection{Desain Penelitian}

Desain penelitian ini menggunakan studi kasus. Pemahaman dari studi kasus merupakan penelitian mendalam tentang masalah penelitian, bukan survei statistik atau pernyataan komperatif. Arikunto (2014 : 185) mengemukakan bahwa penelitian kasus adalah penelitian yang dilakukan secara intensif, terperinci dan mendalam terhadap suatu organisasi, lembaga atau gejala tertentu. Adapun tujuan dari desain penelitian studi kasus untuk mempersempit terhadap bidang yang sangat luas dan kompleks ke dalam suatu hal yang lebih spesifik. Alasan mengapa peneliti menggunakan metode stusi kasus karena peneliti ini akan menliti secara mendalam di kelas X SMK Negeri 03 Salatiga tentang penggunaan media audio visual dalam pembelajaran seni budaya sub materi musik.

\subsection{Lokasi Penelitian}

Peneliti melakukan penelitian di SMK Negeri 03 Salatiga. Sehubungan dengan judul skripsi yaitu : "Penggunaan Media Audio Visual dalam Pembelajaran Seni BudayaSub MateriMusik di SMK Negeri 03 Salatiga", maka lokasi penelitian ini bertempat di sekolah SMK Negeri 03 Salatiga. Yang beralamatkan di jalan Ja'far Shodiq, kelurahan Kalibening RT 01 RW 03, kecamatan Tingkir, kota Salatiga, provinsi Jawa Tengah.

SMK Negeri 03 Salatiga dipimpin oleh bapak Suripan, S.Pd dengan pengajar pendidik 80 guru, siswa laki-laki 1.129 dan siswa perempuan 185, dan terdapat 11 jurusan. Untuk infrastruktur didalam sekolahan SMK Negeri 03 
Salatiga dengan luas tanah $52.700 \mathrm{M}^{2}$ memilki ruang kelas 35, laboratorium 3, perpustakaan 1 .

\subsection{Sasaran Kajian dalam Penelitian}

Peneliti menggunakan obyek yang akan menjadi sasaran penelitian meliputi guru seni budaya di SMK Negeri 03 Salatiga dan siswa kelas X jurusan ototronika dan teknik sepeda motor pada semester genap SMK Negeri 03 Salatiga tahun pelajaran 2016/2017. Melalui penelitian peneliti ingin mengetahui dan ingin memperoleh gambaran tentang keterkaitannya dengan penggunaan media audio visual dalam pembelajaran seni budaya khususnya dalam bidang seni musik di sekolahan SMK Negeri 03 Salatiga. Berkenaan dengan hal itu, maka peneliti akan mengarahkan perhatiannya kepada penggunaan media audio visual dalam pembelajaran seni budaya sub materi musik di SMK Negeri 03 Salatiga.

\subsection{Teknik Pengumpulan Data}

Peneliti menggunakan instrumen atau alat pengambilan data seperti observasi, wawancara dan dokumentasi. Hal ini sesuai dengan pendapat Sugiyono (2015: 308), tanpa mengetahui teknik pengumpulan data, maka peneliti tidak akan mendapatkan data yang memenuhi standar data yang ditetapkan dalam suatu penelitian akan terjadi proses pengumpulan data. Data yang akan diambil atau akan dikumpulkan tersebut biasanya menggunakan beberapa metode. Metode yang digunakan jelas menentukan hasil yang didapat den metode yang dipakai juga harus disesuaikan dengan kondisi, sifat, dan karakteristik dari objek yang 
akan diteliti. Beberapa instrumen atau alat pengambil data dijabarkan sebagai berikut :

\subsubsection{Observasi}

\subsubsection{Teknik Observasi}

Observasi dilakukan pada saat tahun ajaran 2016/2017 semester genap di SMK Negeri 03 Salatiga kelas X jurusan ototronika dan teknik sepeda motor. Peneliti dalam melakukan observasi mengamati tentang proses pembelajaran menggunakan media audio visual. Sasaran observasi dalam penelitian ini lebih mengamati ke guru pada saat menggunakan media audio visual dan peserta didik sebagai penerima dari penggunaan media tersebut. Sutrisno Hadi (1986) dalam Sugiyono (2013 : 145) mengemukakan bahwa, observasi merupakan suatu proses yang kompleks, suatu proses yang tersusun dari berbagai proses biologis dan psikologis. Dua diantaranya yang terpenting adalah proses-proses pengamatan dan ingatan. Observasi ini dilakukan untuk dapat memperoleh catatan mengenai halhal penting yang bersangkutan dengan penelitian dan data yang diperlukan. Selama melakukan pengamatan, peneliti mengadakan pencatatan secara sistematis dan terperinci.

\subsubsection{Jenis Observasi}

Jenis observasi yang dilakukan pada penelitian ini adalah observasi partisipan, karena peneliti terlibat langsung dalam proses pengambilan data pada saat pembelajaran sedang berlangsung. Observasi dilaksanakan pada saat pembelajaran sedang berlangsung. Menurut Sugiyono (2013: 145), dari segi proses pelaksanaan pengumpulan data, observasi dibedakan menjadi participant 
observation (observasi berperan serta) dan non participant observation. Dalam observasi partisipan/berperan serta, peneliti terlibat dengan kegiatan sehari-hari orang yang sedang diamati atau yang digunakan sebagai sumber data penelitian, sedangkan dalam observasi non partisipan peneliti tidak terlibat dan hanya sebagai pengamat.

\subsubsection{Objek Observasi}

Objek observasi dalam penelitian ini adalah siswa kelas X SMK Negeri 03 Salatiga tahun pelajaran 2016/2017. Sesuai dengan kelas yang diampu oleh bapak Sulistyo pada kelas X ototronika dan teknik sepeda motor. Peneliti dalam melakukan observasi mengamati tentang proses pembelajaran seni budaya sub materi musik menggunakan media audio visual.

\subsubsection{Wawancara}

Wawancara dilakukan dengan mewawancarai bapak Sulistyo sebagai guru seni budaya sub materi musik dan enam siswa dari perwakilan kelas masingmasing. Materi wawancara pada bapak Sulistyo adalah berhubungan dengan penggunaan media audio visual dan pada siswa materi yang ditanyakan adalah tentang pendapat mengenai media audio visual. Sesuai dengan pengertian dari wawancara adalah suatu cara pengumpulan data yang digunakan untuk memperoleh informasi langsung dari sumbernya (Riduwan, 2013: 74). Arikunto (2013: 44) menyatakan bahwa wawancara atau interviu (interview) merupakan suatu metode atau cara yang digunakan untuk mendapatkan jawaban dari responden dengan cara tanya jawab sepihak. Dikatakan sepihak karena dalam 
wawancara ini responden tidak diberi kesempatan sama sekali untuk mengajukan pertanyaan.

\subsubsection{Jenis Wawancara}

Jenis wawancara yang digunakan penelitian ini yaitu langsung atau tatap muka, menggunakan alat bantu untuk merekam proses berjalannya wawancara berlangsung. Bentuk wawancara secara langsung akan mendapatkan informasi lebih dalam dan lebih luas karena proses wawancara saling berhadap-hadapan.

\subsubsection{Teknik Wawancara}

Wawancara yang digunakan dalam penelitian ini yaitu wawancara tidak terstruktur. Teknik ini ditujukan untuk guru seni budaya dan siswa di SMK Negeri 03 Salatiga. Wawancara tidak terstruktur adalah wawancara yang bebas dimana peneliti tidak menggunakan pedoman wawancara yang telah tersusun secara sistematis dan lengkap untuk pengumpulan datanya (Sugiyono, 2013: 140). Wawancara tidak terstruktur digunakan pada saat studi pendahuluan untuk mendapatkan informasi awal. Informasi awal tersebut berupa jumlah siswa, media pembelajaran yang biasa digunakan, dan proses pembelajaran seni budaya yang biasa dilaksanakan guru.

\subsubsection{Studi Dokumen}

Dalam penelitian ini, teknik studi dokumen digunakan untuk memperoleh berbagai data. Data tersebut berupa foto dan video pembelajaran sebagai bukti dilaksanakannya penelitian serta sebagai penunjang kegiatan penelitian. Sugiyono (2015: 326) mengatakan "dokumentasi adalah catatan peristiwa". Dokumen bisa 
berbentuk tulisan, gambar, atau karya-karya monumental dari seseorang. Dokumentasi yang digunakan dalam penelitian ini yaitu rekap nilai, foto, dan video pembelajaran sebagai bukti dilaksanakannya penelitian dan penunjang kegiatan penelitian. Sebagai bukti telah melakukan observasi adalah dokumentasi sehingga ada bukti nyata dalam melakukan sebuah penelitian.

Menurut Riduwan (2013: 77), dokumentasi adalah ditujukan untuk memperoleh data langsung dari tempat penelitian, meliputi buku-buku yang relevan, peraturan-peraturan, laporan kegiatan, foto-foto, film dokumenter, dan data yang relevan penelitian. Pengumpulan data dengan menggunakan teknik dokumentasi ini digunakan agar hasil penelitian akan semakin dapat dipercaya. Data tersebut didukung dengan foto, video dan dokumen lainnya.

\subsection{Teknik Keabsahan Data}

Keabsahan data diperlukan teknik pemeriksaan, dalam pelaksanaan teknik pemeriksaan didasarkan atas kriteria tertentu. Penelitian ini menggunakan kriteria uji kredibilitas atau derajat kepercayaan dan peneliti menggunakan teknik triangulasi yang secara spesifik digunakan dalam penelitian ini adalah teknik triangulasi sumber. Teknik ini dilakukan dengan membandingkan dan menyilangkan data yang diambil dari sumber data atau informan yang satu dengan informan yang lainnya. Teknik pemeriksaan keabsahan data ini bertujuan untuk membuktikan bahwa data yang diperoleh adalah benar dan valid sesuai dengan fakta yang ada. Sehingga data yang diperoleh dan diteliti dapat terjamin 
kevaliditasannya yang nantinya akan berpengaruh pada hasil akhir penelitian yang juga valid dan dapat dipertanggungjawabkan.

Penelitian ini menggunakan teknik pemeriksaan Triangulasi yaitu teknik pengecekan validitas silang. Menurut William Wiersma (dalam Sugiyono, 2013:273). Pengecekan data silang dilakukan dengan mengkaji antara data yang diambil dari berbagai sumber, teknik pengumpulan data dan waktu.

\subsection{Teknik Analisis Data}

Analisis data adalah proses pencarian dan penyusunan data yang diperoleh dari hasil wawancara, catatan lapangan dan bahan-bahan lain secara sistematis sehingga lebih mudah dipahami dan temuannya dapat diinformasikan kepada orang lain (Bogdan dalam Sugiyono, 2013:244). Menurut Miles dan Huberman, ada tiga aktivitas dalam analisis data, yaitu:

\subsubsection{Reduksi data}

Semakin lama peneliti melakukan proses pengumpulan data di lapangan, maka data yang didapatkan semakin banyak dan semakin kompleks serta rumit. Untuk itu perlu dilakukan analisis data melalui reduksi data. Mereduksi data berarti merangkum, memilih hal-hal yang pokok, memfokuskan pada hal-hal yang penting dan menjurus pada suatu masalah yang akan diteliti dan dipecahkan.

\subsubsection{Data Display (Penyajian Data)}

Setelah data selesai direduksi, selanjutnya dilakukan penyajian data, yakni menghubungkan antara sekumpulan informasi yang tersusun yang sudah 
direduksi agar mendapatkan suatu pola baru dari pola-pola yang sudah terstruktur sebelumnya.

\subsubsection{Penarikan Kesimpulan/Verifikasi}

Langkah ketiga dalam analisis data kualitatif menurut Miles and Huberman adalah penarikan kesimpulan dan verifikasi. Setelah data terkumpul dan semua data selesai diteliti, maka dapat diambil sebuah kesimpulan awal yang berdasarkan data-data yang diperoleh dalam proses pengumpulan data sebelumya. Kesimpulan yang dikemukakan masih bersifat sementara dan bisa berubah jikan tidak ditemukan bukti-bukti yang kuat yang mendukung pada tahap pengumpulan data berikutnya. Jika kesimpulan yang dikemukakan valid dan tetap konsisten saat peneliti kembali ke lapangan untuk mengumpulkan bukti, maka kesimpulan ini dianggap kredibel.

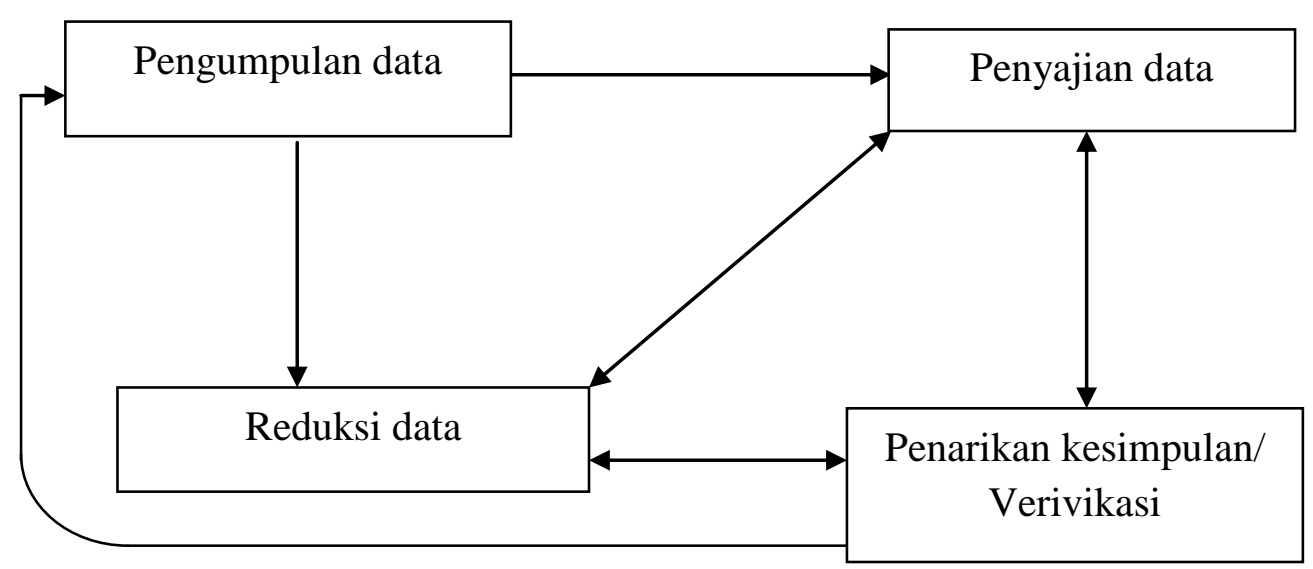

Bagan 3.1

Komponen-Komponen Analisis Data Model Interaktif

Sumber : Metode Penelitian Kuantitatif Kualitatif dan R\&D (Sugiyono, 2013:247) 


\section{BAB IV}

\section{HASIL PENELITIAN DAN PEMBAHASAN}

Hasil penelitian dan pembahasan merupakan bab ke-IV dalam penelitian. Bagian ini membahas tentang penggunaan media audio visual dalam pembelajaran seni budaya sub materi musik di SMK Negeri 03 Salatiga yang terdiri dari (1) gambaran umum lokasi penelitian dan (2) penggunan media audio visual dalam pembelajaran seni budaya sub materi musik di SMK Negeri 03 Salatiga. Penjelasan selengkapnya sebagai berikut.

\subsection{Gambaran Umum Lokasi Penelitian}

Peneliti menjelaskan tentang gambaran umum pada lokasi penelitian yang terdiri dari letak dan kondisi geografis, berdirinya sekolah, struktur organisasi, program keahlian, prestasi, serta sarana dan prasarana SMK Negeri 03 Salatiga.

\subsubsection{Letak dan Kondisi Geografis SMK Negeri 03 Salatiga}

SMK Negeri 03 Salatiga merupakan sebuah sekolahan menengah kejuruan (SMK) yang berdiri di kota Salatiga dengan beralamatkan jalan Ja'far Shodiq, kelurahan Kalibening Rt.01 Rw.03, kecamatan Tinggir, kota Salatiga. Potensi SMK Negeri 03 Salatiga didukung dengan luas lahan $52.700 \mathrm{~m}^{2}$, luas bangunan $4910 \mathrm{~m}^{2}$ dan luas lahan kosong $47.828 \mathrm{~m}^{2}$. 


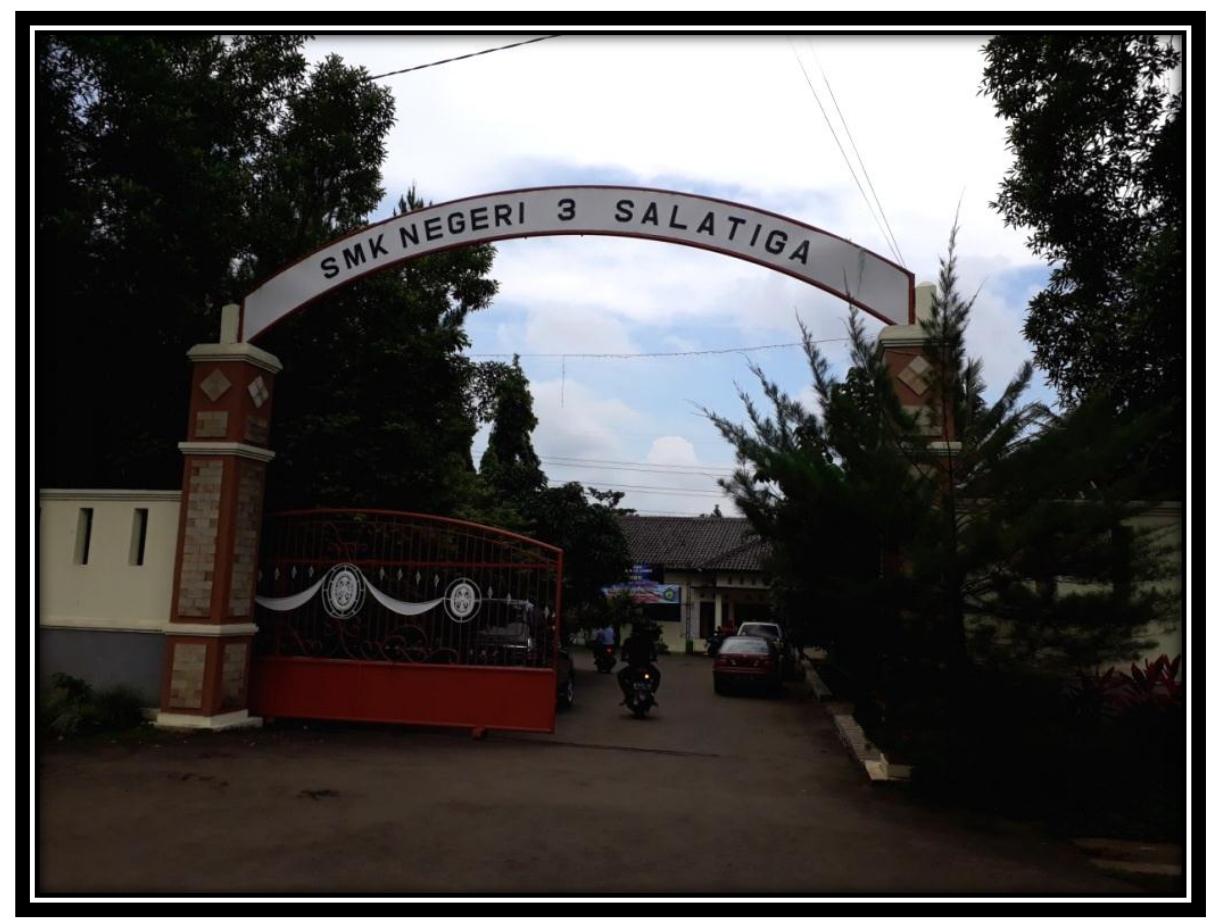

Foto 4.1

Gerbang Sekolah SMK Negeri 03 Salatiga

(Sumber: Angga Dwi Winarno, Mei 2017)

Lokasi SMK Negeri 03 Salatiga cukup strategi, dilihat dari letaknya SMK Negeri 03 Salatiga berada di sekitar rumah warga dan berdekaan dengan beberapa sekolahan dan pondok pesantren seperti SMP Negeri 08 Salatiga, SMP Kristen 2 Salatiga, Taman Pendidikan Al Qur'an An Nida, SD Negeri Ledok 1, Pondok Pesantren Sunan Giri dan Pondok Pesantren Hidayatul Mubtadiin, sehingga banyak peserta didik di SMK Negeri 03 Salatigayang berasal dari siswa sekolah-sekolah dan warga masyarakat sekitarSMK Negeri 03 Salatiga.

\subsubsection{Berdirinya SMK Negeri 03 Salatiga}

SMK Negeri 03 Salatiga yang berdiri di kota Salatiga pada tanggal 21 Mei 2007 atas persetujuan pemerintah kota Salatiga. Lokasi yang cukup strategis 
yang berlokasi di jalan Ja'far Shodiq, kelurahan Kalibening Rt.01 Rw.03, kecamatan Tinggir, kota Salatiga. Berdasarkan hasil wawancara dengan bapak Suripan selaku kepala sekolah SMK Negeri 03 Salatiga menjelaskan bahwa pada awalnya bernama SMK Negeri 01 Tingkir tapi pada tanggal 20 Mei 2007 resmi berganti nama menjadi SMK Negeri 03 Salatiga.

SMK Negeri 03 Salatiga merupakan sekolah menengah kejuruan berstatus negeri termuda di Kota Salatiga. Sekolah ini juga pernah menjadi salah satu sekolah RSBI (Rintisan Sekolah Bertaraf Internasional) meskipun RSBI sendiri telah dihapus oleh Mahkamah Konstitusi secara nasional pada tanggal 8 Januari 2013. Keberadaan SMK Negeri 03 Salatiga telah lama diharapkan oleh masyarakat khususnya kota Salatiga, untuk menjawab kebutuhan pendidikan yang beragam dan berkualitas. Keberadaan SMK Negeri 03 Salatiga dituangkan dengan surat keputusan operasional penyelenggara program keahlian No:420.5/1510 Kepala Dinas Pendidikan Kota Salatiga tanggal 21 Mei 2007.

Pemilihan lokasi yang berada di daerah Kelurahan Kalibening karena pertimbangan keinginan masyarakat terhadap adanya sekolah menengah negeri di daerah tersebut dan keinginan pemerintah Kota Salatiga untuk mengembangkan potensi daerah yang ada. Keberadaan SMK Negeri 03 Salatiga diharapkan dapat mewujudkan pengembangan potensi daerah yang berdampak positif bagi peningkatan kesejahteraan masyarakat sekitar. Setalah tahun 2007 SMK Negeri 03 Salatiga diresmikan, pada tahun 2010 tetapnya tanggal 2 Agustus 2010 bertempat di lapangan upacara SMK Negeri 03 Salatiga dilaksanakan pembacaan pernyataan dimulainya Implementasi ISO 9001-2008 di SMK Negeri 03 Salatiga 
dengan dibacakannya Surat Keputusan Kepala Sekolah Menengah Kejuruan Negeri Salatiga, tentang "PENETAPAN IMPEMENTASI SISTEM MANAJEMEN MUTU (SMM) STANDART ISO 9001-2008 DI SMK NEGERI 03 SALATIGA" tertanggal 2 Agustus 2010 oleh kepala sekolah SMK Negeri 03 Salatiga bapak Kamaruddin yang sekarang telah digantikan oleh bapak Suripan.

SMK Negeri 03 Salatiga dengan motto "Cerdas Berkualitas" yang mempunyai maskot yang ada di logo SMK Negeri 03 Salatiga terdapat 3 lilin berjajar ini mempunyai sebuah visi dan misi yang bekompeten. Dibawah pimpinan bapak Suripan visi dari SMK Negeri 03 Salatiga yaitu "Menyelenggaranakan pendidikan yang berkarakter SMART (Sejahtera, Mandiri, Bermatabat) untuk menghasilkan tamatan berakhlak mulia dan berwawasan lingkungan yang siap bersaing di era global”. Sedangkan misi dari SMK Negeri 03 Salatiga mempunyai 4 misi yaitu : (1) menyelenggarakan sekolah yang mendasarkan nilai-nilai religius untuk menumbuhkan akhlak mulia dan ketakwaan terhadap Tuhan Yang Maha Esa; (2) menciptakan lingkungan sekolah yang indah, bersih, tertata, dan nyaman; (3) menyiapkan tamatan yang mengedepankan soft skill yang mampu bersaing di era global; (4) menyelenggarakan pendidikan yang disiplin, terbuka, dan akuntabel.

\subsubsection{Struktur Organisasi SMK Negeri 03 Salatiga}

\subsubsection{Pengurus}

Berdasarkan dokumentasi yang dilakukan oleh peneliti, didapatkan struktur organisasi kepengurusan SMK Negeri 03 Salatiga. Berikut ini adalah 
susunan kepengurusan struktur organisasi SMK Negeri 03 Salatiga : (1) Kepala SMK Negeri 03 Salatiga oleh Suripan, S.Pd ; (2) Wakil Kepala Sekolah Bidang OPENDIKUR oleh Indaryanto, S.Pd.T ; (3) Wakil Kepala Sekolah Bidang Kesiswaan oleh Dyah Sulistyorini, S.Pd ; (4) Wakil Kepala Sekolah Bidang Hubungan Masyarakat dan Hubungan Industri oleh Daud Lanang Prabowo, S.Pd ; (5) Wakil Kepala Sekolah Bidang Sarana dan Prasarana oleh Siswanto, S.Pd ; (6) Wakil Kepala Sekolah Bidang Ketenagaan dan Sumber Daya Manusia oleh Drs. Muhammad Thowil.

\subsubsection{Staf Pengajar dan Karyawan}

Staf pengajar yang ada di SMK Negeri 03 Salatiga memiliki latar belakang pendidik yang berbeda-beda, sesuai bidang mata pelajaran yang diampu masing-masing. Kemampuan pengajar SMK Negeri 03 Salatiga sudah tidak diragukan lagi, karena tenaga pengajar yang ada di SMK Negeri 03 Salatiga memang staf pengajar yang sudahberpengalaman dan mumpuni di bidangnya. Staf pengajar SMK Negeri 03 Salatiga pada tahun ajaran 2015/2016 memiliki 81 staf pengajar yang terdiri dari 48 staf guru PNS dan 33 staf guru tidak tetap (GTT).

Jumlah karyawan SMK Negeri 03 Salatiga pada tahun ajaran 2015/2016 sejumlah 18 karyawan , 3 karyawan PNS dan 15 karyawan tidak tetap. Karyawan tersebut terdiri dari 1 orang koordinator tata usaha, 1 orang verifikator keuangan, 3 staf kantor, 4 orang toolman jurusan, 1 orang karyawan perpustakaan, 2 orang satpam, 3 oranng penjaga malam, 3 orang tukang kebun, 3 orang karyawan kebersihan. Berikut ini adalah daftar staf pengajar dan karyawan SMK Negeri 03 Salatiga : 


\begin{tabular}{|c|c|c|}
\hline NO. & NAMA & KETERANGAN \\
\hline 1. & Suripan, S.Pd. & Kepala Sekolah \\
\hline 2. & Dra. Sri Hartati & Pend.Kewarganegaraan \\
\hline 3. & Drs. Paulus Hau Pita & $\mathrm{BP} / \mathrm{BK}$ \\
\hline 4. & Nuridah, S.Pd. & Matematika \\
\hline 5. & Drs. Muh Towil & Bhs.Indonesia \\
\hline 6. & Sugiartini, S.Pd. & Geografi \\
\hline 7. & Dra. Ngizatun & $\mathrm{BP} / \mathrm{BK}$ \\
\hline 8. & Dian Adriyanto, S.Pd., M.Pd. & Teknik Kendaraan Ringan \\
\hline 9. & Dulhadi, S.Ag., M.Pd.I. & Pend. Agama Islam \\
\hline 10. & Adria Vineta, S. Si & Biologi/IPA \\
\hline 11. & Asih Niyati,S.Pd & Ekonomi \\
\hline 12. & Lamini, S.Pd. & $\mathrm{BP} / \mathrm{BK}$ \\
\hline 13. & Siti Sulaikah, S.Pd., M.Pd. & Bhs.Inggris \\
\hline 14. & Hery Ridawati,S.Pd. & PKn \\
\hline 15. & Fitri Nurhayati Sih W., S.Pt. & Kima / Fisika \\
\hline 16. & Dyah Sulistyorini, S. Pd. & Matematika \\
\hline 17. & M. Hafid, S. Ag. & Pend.Agama Islam \\
\hline 18. & Drs. Sugeng Winarto & Teknik Las \\
\hline 19. & Mariati, S. Pd., M.Pd. & Teknik Mekatronika \\
\hline 20. & Sri Supadmi, S. Pd. & Bhs.Inggris \\
\hline 21. & Anis Fadilah, S. Pd. & Matematika \\
\hline 22. & Achiruddin Pasila, S.Pd. & Penjaskes \\
\hline
\end{tabular}




\begin{tabular}{|c|c|c|}
\hline 23. & Indaryanto, S.Pd.T. & Teknik Pengelasan \\
\hline 24. & Sulistiyo, S.Pd. & Seni Budaya \\
\hline 25 . & Ani Kurniasari, S.Pd. & Kimia \\
\hline 26. & Daniel Adi Prabowo, S.Pd. & Bahasa Jawa \\
\hline 27. & Hendrik Ade Putra, S.Pd. & Teknik Mekatronika \\
\hline 28. & Puji Wijayanti, S.Pd. & Bahasa Indonesia \\
\hline 29. & Siswanto, S. Pd. & Teknik Ototronika \\
\hline 30. & Heru Lukman Wicaksono, S. Pd. & Bahasa Jepang \\
\hline 31. & Devy Listyowati,S.P. & Produktif Budidaya \\
\hline 32. & Dewi Fatihatuzulfa, S.Psi. & $\mathrm{BP} / \mathrm{BK}$ \\
\hline 33. & Djaru Purnomo, S.Pd. & Teknik Mesin \\
\hline 34. & Sukiningsih, S.Pd. & Teknik Mesin \\
\hline 35. & Daud Lanang Prabowo, S.Pd. & Teknik Mekatronika \\
\hline 36. & Syaefudin Afan Eko H., S.T & Teknik Mesin \\
\hline 37. & Ayustina Krisniati, S.P. & Pertanian \\
\hline 38. & Ifana Tri Kusumastuti, S. P. & Pertanian \\
\hline 39. & Zainal Arifin, S. Pd.T. & Teknik Mekatronika \\
\hline 40. & Mahetasari, S.Ant. & Sejarah Ind/Prakary\&KWR \\
\hline 41. & Eko Listyo Sahono, S.Pd. & Teknik Mesin \\
\hline 42. & Samsul Huda, S.Pd. & Pend.Teknik Otomotif \\
\hline 43. & Arif Rusgiono, S.Pd. & Pend.Teknik Otomotif \\
\hline 44. & Sidiq Suprayogi, S.Pd. & Pend.Teknik Otomotif \\
\hline 45. & Cahyono Dwi Atmoko, S.Pd.T. & Pend.Teknik Otomotif \\
\hline
\end{tabular}




\begin{tabular}{|c|c|c|}
\hline 46. & Eko Noferi Yanto, S.Pd. & Pend.Teknik Otomotif \\
\hline 47. & Dimas Nico Saputra, S.Pd. & Pend.Teknik Otomotif \\
\hline 48. & Retno Agustin Dwi A., S.Pd. & Fisika \\
\hline 49. & Pramesthi Dewi, S.Pd.T. & Prod. Mekatronika/KKPI \\
\hline 50. & Hasan Habib Nur W. , S. Pd.T. & Produktif Mesin \\
\hline 51. & Samuel Ngasto Roso, S.Th. & Pend. Agama Kristen \\
\hline 52. & Anggit Dian Nugroho, S. Pd. & Olah Raga \\
\hline 53. & Hery Winarno, S.P. & Produktif Agro \\
\hline 54. & Ahmad Abdul Mutholib, S.Pd & Matematika \\
\hline 55. & Anton Nugroho,S.P.d & Fisika \\
\hline 56. & Angga Arga Wastu,S.Pd. & Bahasa Inggris \\
\hline 57. & Ardiana Angga W., S.Pd. & Prod. Ototronik \\
\hline 58. & M. Chamid, A.Md. & Simulasi Digital/KKPI \\
\hline 59. & Wiwid Haniffudin, S.Pd. & Prod. Ototronik \\
\hline 60. & Anjar Subagio, S.Pd. & Prakry/KWR/Sim. Digital \\
\hline 61. & Novi Widi Atmaja, S.Pd. & Prod. Ototronika \\
\hline 62. & Oktiva Dwi Cahyono, S.Pd. & Prod. Ototronika \\
\hline 63. & Nurul Fitri, S.Pd. & Bhs. \& Sastra Ind. \\
\hline 64. & Aris Nursaid, S.Pd. & Matematika \\
\hline 65. & Wahyu Sharandavi, S.Pd. & Prod.Mekatronika \\
\hline 66. & Nor Rosidah, S.Pd. & Penjaskes \\
\hline 67. & Uswatun Khasanah, S.Pd. & Bhs. Inggris/Bhs.Ind \\
\hline 68. & Wida Rahayu, S.Pd. & Pendidikan Seni Rupa \\
\hline
\end{tabular}




\begin{tabular}{|c|c|c|}
\hline 69. & Rina Wijayanti, S.Pd. & Pend. Bhs Jawa \\
\hline 70. & Siti Noor Fauziah, S.Pd. & Pend. Fisika \\
\hline 71. & Elys Munadziroh, S.Pd. & Bhs. Indonesia \\
\hline 72. & Fita Indriyani, S.Psi., S.Pd. & $\mathrm{BP} / \mathrm{BK}$ \\
\hline 73. & Nurul Septiana Rahmawati, S.Pd. & Bahasa Jepang \\
\hline 74. & Ema Apriadi, S.Pd. & Bhs. Indonesia \\
\hline 75 . & Danis Eko Suryanto, S.Ag. & Pend.Agama Budha \\
\hline 76. & Wahyu Sriyanti, B.A. & Fisika \\
\hline 77. & Sri Hartini, S.Pd. & Kimia \\
\hline 78. & Dyah Ani, S.Pd. & IPS \\
\hline 79. & Dra. Sri Sulasmini & PKn \\
\hline 80. & Dra. B. Tri Dewi H.E & Matematika \\
\hline 81. & Rita Permana Kelana Wati, S.H.,M.Pd. & PPKn \\
\hline 82. & Joko Maryono, A.Md & Verifikator Keuangan \\
\hline 83. & Eko Yuliani & Staf Keuangan \\
\hline 84. & Tukiman & Staf \\
\hline 85. & Sugimin & Koord. Tata Uasaha \\
\hline 86. & Nazifudin & Penjaga Malam \\
\hline 87. & Harmin & Kebersihan \\
\hline 88. & Faizal Ahmad Afiyudin & Penjaga Malam \\
\hline 89. & Mohamad Toha Al Hasan & Satpam \\
\hline 90. & Muhtari & Tukang Kebun \\
\hline 91. & Muh. Dahlan & Tukang Kebun \\
\hline
\end{tabular}




\begin{tabular}{|l|l|l|}
\hline 92. & Munawir & Tukang Kebun \\
93. & Buang & Kebersihan \\
94. & Indro Setyo Permono & Satpam \\
95. & Devis Afista Krishna Nanda Z. & Toolman Ototronika \\
96. & Nugroho & Toolman Mekatronika \\
97. & Sriyono & Kebersihan \\
98. & Ahmat Saiful Khadiqunnuha & Penjaga Malam \\
99. & Muhammad Bagus Wicaksono & Toolman Wlding \\
100. & Afdlol Legowo & Toolman Ototronika \\
101. & Adam Tri Laksono & Perpustakaan \\
102. & Yuli Supriyatiningsih & Staf \\
\hline
\end{tabular}

Tabel 4.1

Staf Pengajar Dan Karyawan SMK Negeri 03 Salatiga

(Sumber: Angga Dwi Winarno, 2017)

\subsubsection{Program Keahlian diSMK Negeri 03 Salatiga}

SMK Negeri 03 Salatiga merupakan sekolah kejuruan yang berkompeten , untuk itu SMK Negeri 03 Salatiga pada tahun ajaran 2014/2015 memiliki 6 kompetensi keahlian yang sudah tidak diragukan lagi dalam kualitas pendidikan dan proses dalam pembelajarannya. Berikut kompetensi keahlian di SMK Negeri 03 Salatiga :

\subsubsection{Teknik Mekatronika}

Teknik Mekatronika di SMK Negeri 03 Salatiga mempelajari tentang sistem kontrol elektronika dan mekanik, robotika, sistem otomasi dalam industri 
berbasis PLC, Mikrokontroler, Pneumatik dan Hidrolik, serta Motor Listrik. Mekatronika merupakan suatu disiplin ilmu teknik yang mengkombinasikan sinergi dari teknik mesin, elektronika dan teknik komputer. Teknik Mekatronika pada tahun pelajaran 2016/2017 jumlah siswa kelas X berjumlah 72 siswa yang dibagi mejadi 2 rombel. Pada siswa kelas XI berjumlah 76 siswa yang dibagi mejadi 2 rombel. Sedangkan, siswa kelas XII berjumlah 70 siswa yang dibagi mejadi 2 rombel juga.

\subsubsection{Teknik Pengelasan}

Teknik Pengelasan di SMK Negeri 03 Salatiga mempelajari tentang teknik-teknik pengelasan antara lain Las Oxy/Acetylene, Las busur manual, Las MIG, Las TIG dengan posisi 1G, 2G, 3G, serta Pekerjaan Pemesinan dan Fabrikasi Logam.Teknik Pengelasan pada tahun pelajaran 2016/2017 jumlah siswa kelas $\mathrm{X}$ berjumlah 68 siswa yang dibagi mejadi 2 rombel. Pada siswa kelas XI berjumlah 67 siswa yang dibagi mejadi 2 rombel. Sedangkan, siswa kelas XII berjumlah 68 siswa yang dibagi mejadi 2 rombel juga.

\subsubsection{Agribisnis Tanaman Pangan dan Hortikultura}

Agribisnis Tanaman Pangan dan Hortikultura mempelajari tentang teknik pembudidayaan tanaman pangan, perawatan tamanan, dan pemasaran pasca panen.Agribisnis Tanaman Pangan dan Hortikultura pada tahun pelajaran 2016/2017 jumlah siswa kelas X berjumlah 62 siswa yang dibagi mejadi 2 rombel. Pada siswa kelas XI berjumlah 73 siswa yang dibagi mejadi 2 rombel. Sedangkan, siswa kelas XII berjumlah 75 siswa yang dibagi mejadi 2 rombel juga. 


\subsubsection{Teknik Ototronika}

Teknik Ototronika mempelajari tentang teknologi kendaraan bermotor khususnya roda 4 , baik teknologi mesin, otomasi dalam kendaraan, perawatan kendaraan, kelistrikan kendaraan, dll.Teknik Ototronika pada tahun pelajaran 2016/2017 jumlah siswa kelas X berjumlah 106 siswa yang dibagi mejadi 3 rombel. Pada siswa kelas XI berjumlah 100 siswa yang dibagi mejadi 3 rombel. Sedangkan, siswa kelas XII berjumlah 105 siswa yang dibagi mejadi 2 rombel juga.

\subsubsection{Teknik Sepeda Motor}

Teknik Sepeda Motor mempelajari tentang teknologi kendaraan khususnya roda 2, baik teknologi mesin konvensional, injeksi, kelistrikan, dan perawatan sepeda motor.Teknik Sepeda Motor pada tahun pelajaran 2016/2017 jumlah siswa kelas $\mathrm{X}$ berjumlah 102 siswa yang dibagi mejadi 3 rombel. Pada siswa kelas XI berjumlah 110 siswa yang dibagi mejadi 3 rombel. Sedangkan, siswa kelas XII berjumlah 96 siswa yang dibagi mejadi 4 rombel juga.

\subsubsection{Teknik Survey dan Pemetaan (Geomatika)}

Teknik Survey dan Pemetaan mempelajari teknik tenik pemetaan wilayah, sistem informasi geografis, penyajian data spasial, dll.Teknik Survey dan Pemetaan pada tahun pelajaran 2016/2017 jumlah siswa kelas X berjumlah 35 siswa yang dibagi mejadi 1 rombel. Pada siswa kelas XI berjumlah 36 siswa yang dibagi mejadi 1 rombel. Berhubung Teknik Survey dan Pemetaan merupakan jurusan baru untuk pembukaan siswanya pada tahun ajaran 2014/2015, maka untuk kelas XII belum ada siswanya. 


\subsubsection{Prestasi SMK Negeri 03 Salatiga}

Prestasi yang telah diraih dalam bidang akademik maupun non akademik oleh SMK Negerii 03 Salatiga sangatlah banyak. Peneliti melakukan kegiatan wawancara dengan bapak Sulistyo selaku guru seni budaya, untuk prestasi seni musik yang telah diraih pada semester kemarin meliputi lomba gitar klasik tingkat provinsi mendapatkan juara 2, lomba aransemen lagu natal di Universitas Kristes Satya Wacana mendapatkan juara 2, lomba bernyanyi solo vokal di Universitas Kristes Satya Wacana mendapatkan juara 3, dan lomba di STAIN solo vokal mendapatkan juara 2. Berikut merupakan prestasi-prestasi SMK Negerii 03 Salatiga dalam bidang seni musik pada akhir-akhir semester kemarin.

\subsubsection{Sarana dan Prasarana di SMK Negeri 03 Salatiga}

SMK Negeri 03 Salatiga memiliki sarana dan prasarana untuk mata pelajaran seni budaya khususnya seni musik yang dapat menunjang kegiatan belajar musik untuk meningkatkan kreatifitas dan melaksanakan kegiatan belajar mengajar di SMK Negeri 03 Salatiga. Peralatan alat musik di SMK Negeri 03 Salatiga sangat lengkap dan terawat, karena ada pengawasan langsung dari bapak Sulistyo selaku pengajar seni budaya (Seni Musik). Peralatan alat musik dijadikan satu di ruangan khusus dan setiap alat yang digunakan saat proses pembelajaran atau untuk latihan siswa, diawasi langsung oleh bapak sulistyo. 
Berikut ini adalah daftar alat musik SMK Negeri 03 Salatiga :

\begin{tabular}{|c|l|l|c|c|c|c|}
\hline \multirow{2}{*}{ No. } & \multirow{2}{*}{ Nama Barang } & \multirow{2}{*}{ Merk } & \multirow{2}{*}{ Jumla } & \multicolumn{3}{|c|}{ Keadaan Barang } \\
\cline { 5 - 7 } & & & h & Baik & $\begin{array}{c}\text { Kuran } \\
\text { a Rail }\end{array}$ & Rusak \\
\hline 1 & Ampli Gitar & Cora & 1 & $\sqrt{ }$ & & \\
\hline 2 & Ampli Gitar & Gillmore & 1 & $\sqrt{ }$ & & \\
\hline 3 & Ampli Bass & Cora & 1 & $\sqrt{ }$ & & \\
\hline 4 & Ampli Keyboard & Behringer & 1 & $\sqrt{ }$ & & \\
\hline 5 & Ampli Gitar & Beicat & 1 & $\sqrt{ }$ & & \\
\hline 6 & Drum & Pearl & 1 & $\sqrt{ }$ & & \\
\hline 7 & Gitar Elektrik & Squier Strat. & 1 & $\sqrt{ }$ & & \\
\hline 8 & Gitar Elektrik & Squier Tele. & 1 & $\sqrt{ }$ & & \\
\hline 9 & Gitar Elektrik & X-Cort & 1 & & $\sqrt{ }$ & \\
\hline 10 & Bass Elektrik & Squier & 1 & $\sqrt{ }$ & & \\
\hline 11 & Gitar Akustik & Taylor & 1 & $\sqrt{ }$ & & \\
\hline 12 & Gitar Akustik & Gillmore & 1 & & $\sqrt{ }$ & \\
\hline 13 & Gitar Akustik & Yamaha C & 4 & $\sqrt{ }$ & & \\
\hline 14 & Bass Akustik & Cort & 1 & $\sqrt{ }$ & & \\
\hline 15 & Keyboard & Yamaha & 1 & V & & \\
\hline 16 & Cajon & Pearl & 1 & $\sqrt{ }$ & & \\
\hline 17 & Gitar Akustik & Yamaha Cx & 1 & V & & \\
\hline 18 & Mic & Samson & 2 & V & & \\
\hline 19 & Mic & Visiencer & 2 & $\sqrt{ }$ & & \\
\hline 20 & Jimbe & & 2 & $\sqrt{ }$ & & \\
\hline 21 & Stand Mic & Samson & 1 & $\sqrt{ }$ & & \\
\hline & & & & & & \\
\hline
\end{tabular}

Tabel 4.2

Daftar Alat Musik SMK Negeri 03 Salatiga

(Sumber : Angga Dwi Winarno, Mei 2017) 


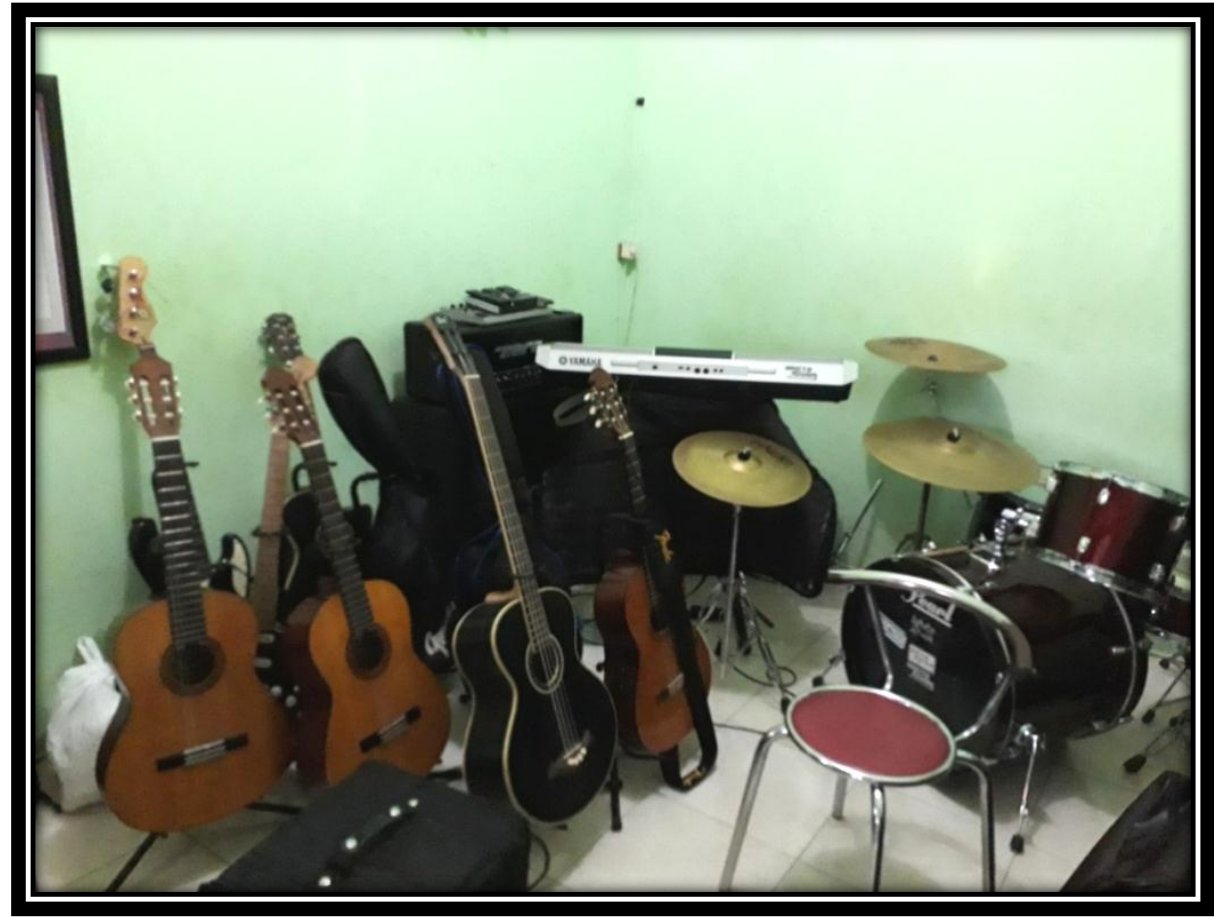

to 4.2

Fo

Kondisi Studio Musik SMK Negeri 03 Salatiga

(Sumber: Angga Dwi Winarno, Mei 2017)

\subsection{Penggunaan Media Audio Visual dalam Pembelajaran Seni Budaya Sub Materi Musik di SMK Negeri 03 Salatiga}

Sesusai rumusan masalah yang telah ada yaitu bagaimana penggunaan media audio visual dalam pembelajaran seni budaya sub materi musik di SMK Negeri 03 Salatiga. Penelitian ini dilaksanakan pada bulan Mei 2017 di SMK Negeri 03 Salatiga pada tahun pelajaran 2016/2017 yang telah melakukan pengambilan data secara observasi, wawancara, dokumentasi. Peneliti telah mengobservasi tentang gambaran lokasi penelitian dan bagaimana penggunaan media audio visual dalam pembelajaran seni budaya sub materi musik di SMK Negeri 03 Salatiga. Peneliti juga telah melakukan wawancara kepada Bapak 
Sulistyo, S.Pd selaku guru mata pelajaran seni budaya sub materi musik serta dokumentasi tentang yang berhubugan dengan masalah yang ada.

Peneliti juga melakukan sebuah observasi tentang penggunaan media audio visual dalam pembelajaran seni budaya sub materi musik di SMK Negeri 03 Salatiga, karena pada kelas X mata pelajaran seni budaya sub materi musik bergiliran dengan seni rupa per semester untuk itu peneliti melakukan penelitian pada jurusan ototronika dan teknik sepeda motor yang di ampu oleh Bapak Sulistyo S.Pd. Peneliti melakukan pengamatan pada setiap proses pembelajaran di tiga kelas tersebut.

\subsubsection{Tahap Perencanaan Pembelajaran}

Sesuai dengan penelitian yang sudah dilakukan menggunakan instrumen penelitian berupa observasi, wawancara dan dokumentasi mengenai perencanaan pembelajaran, maka guru dalam melakukaan perencanaan pembelajaran akan mengembangan silabus yang sudah ada, menyusun Rencana Pelaksanaan Pembelajaran (RPP), menyiapkan meteri ajaran dan mempersiapkan media pembelajaran yang akan digunakan. Perencanaan pembelajaran sama hal nya dengan pengertian dari Gagne (1981) tentang pembelajaran merupakan serangkaian peristiwa eksternal peserta didik yang dirancang untuk mendukung proses internal belajar (Achmad rifa'i dan Catharina 2012 : 158-159). Setelah dilakukan penelitian, peneliti mendapatkan hasil sebagai berikut : 


\subsubsection{Mengembangkan Silabus}

Sekolah Menengah Kejuraan (SMK) Negeri 03 Salatiga sudah menggunakan kurikulum 2013 revisi, jadi guru mengembangkan silabus yang sudah ditetapkan oleh pemerintah. Silabus inilah akan dijabarkan setiap indikatornya menjadi suatu Rencana Pelaksana Pembelajaran (RPP).Menurut hasil observasi pada bulan April 2017 materi pembelajaran seni musik pada kelas X di SMK Negeri 03 Salatiga sebagai berikut : menunjukkan sikap penghayatan dan pengalaman serta bangga terhadap seni musik sebagai bentuk rasa syukur terhadap anugerah Tuhan (KD. 1.1), menunjukkan sikap kerjasama, bertanggung jawab, toleran, dan disiplin melalui aktivitas berkesenian (KD. 2.1), menunjukkan sikap santun, jujur, cinta, damai, dalam mengapresiasi seni dan pembuatnya (KD. 2.2), menunjukkan sikap responsif, pro-aktif, dan peduli terhadap lingkungan dan sesama, serta menghargai karya seni dan pembuatannya (KD. 2.3), memahami karya musik berdasarkan simbol, jenis nilai estetis dan fungsinya (KD. 3.1), menyanyikan lagu-lagu berdasarkan jenisnya (KD. 4.1), menganalisis karya musik berdasarkan simbol, jenis nilai estetis dan fungsinya (KD. 3.2), menampilkan permainan musik berdasarkan jenisnya (KD. 4.2), memahami rancangan pergelaran musik (KD. 3.3), mempergelarkan musik dengan memperhatikan nilai-nilai estetis (KD. 4.3), menganalisis karya-karya musik dan kegiatan pergelaran musik (KD. 3.4), membuat tulisan tentang beragam musik dan lagu-lagunya (KD. 4.4). Materi tersebut merupakan kurikulum 2013 yang sudah di revisi. Sesuai dengan apa yang dijelaskan oleh guru mata pelajaran seni budaya sub materi musik saat peneliti melakukan wawancara : 
"kurikulum 2013 yang sudah revisi, jadi kita mengikuti itu. Dulu sudah ada revisi sekarang juga ada revisi lagi”

Silabus merupakan pedoman dalam menyusun rencana kegiatan pembelajaran pada setiap mata pelajaran, dan kegiatan pembelajaran. Silabus pada pembelajaran seni budaya sub materi musik untuk kelas $\mathrm{X}$ yang sudah dikembangkan oleh guru dapat dilihat pada lampiran 8 dan halaman 96.

\subsubsection{Menyusunan Rencana Pelaksanaan Pembelajaran (RPP)}

Penyusunan Rencana Pelaksanaan Pembelajaran (RPP) di SMK Negeri 03 Salatiga guru seni budaya sub materi musik dalam penyusunannya menyesuaikan dengan kondisi yang ada. Penyesuaian dengan kondisi yang ada dikarenakanpembelajaran Seni Musik di SMK Negeri 03 Salatiga tahun pelajaran 2016/2017 khususnya pada kelas X jurusan ototronika dan teknik sepeda motor mendapatkan alokasi waktu 4 jam pelajaran dan berlangsung 2 minggu sekali, jadi sistem ini disebut sistem blok yang sudah diatur dari pihak sekolah. Sistem blok penjelasannya yaitu jika minggu pertama pembelajaran non jurusan, maka pada minggu kedua pembelajaranya yaitu pemebelajaran praktek jurusan masingmasing. Alasannya dibuat sistem blok dikarenakan agar siswa bisa fokus dan alokasi waktu saat praktek juga bertambah banyak. Menurut Bapak Sulistyo menjelaskan tentang pelaksanaan proses belajar mengajar tidak memungkinkan di studio musik dikarenakan ruangan yang tidak memadahi, jadi segala proses selama pembelajaran seni musik berada didalam kelas masing-masing.

Rencana Pelaksanaan Pembelajaran (RPP) adalah rencana kegiatan pembelajaran tatap muka untuk satu pertemuan atau lebih. RPP dikembangkan dari silabus untuk mengarahkan kegiatan pembelajaran peserta didik dalam upaya 
mencapai Kompetensi Dasar (KD). Didalam penyusunan Rencana PelaksanaanPembelajaran (RPP) yang dijelaskan dalam Permendikbud No. 103 Tahun 2014dituliskan tentang komponen RPP yang terdiri dari (1) identitas sekolah/madrasah, mata pelajaran, dan kelas/semester; (2) alokasi waktu; (3) KI, $\mathrm{KD}$, indikator pencapaian kompetensi; (4) materi pembelajaran; (5) kegiatan pembelajaran; (6) penilaian: dan (7) media/alat, bahan, dan sumber belajar. Contoh RPP yang digunakan untuk kelas $\mathrm{X}$ dapat dilihat dilampiran 9 dan halaman 101.

\subsubsection{Menyiapkan Materi dan Media Pembelajaran}

Sebelum masuk kelas guru terlebih dahulu menyiapkan materi yang akan disampaikan kepada siswa. Persiapan materi saat mengajar harus dipersiapkan dengan baik supaya pesan dari materi tersampaikan kepada siswa, sama halnya dengan pengertian mengajar menurut Pupuh dan Sobry (2007 : 8), mengajar merupakan suatu perbuatan yang kompleks, perbuatan mengajar yang kompleks dapat diterjemahkan sebagai penggunaan secara integratif secara komponen yang terkandung dalam perbuatan mengajar itu untuk menyampaikan pesan pengajaran. Materi yang digunakan sesuai dengan instrumen pembelajaran yang telah dikembangkan menyesuaikan kondisi di SMK Negeri 03 Salatiga. Penyampaian materi tidak hanya tertuju pada buku ajar, tapi bapak Sulistyo memberikan kebebasan kepada siswa untuk membawa alat elektronik yang dapat terkoneksi dengan internet seperti laptop, telepon genggam dan table. Hal itu diperbolehkan supaya siswa mencari informasi pada materi tidak hanya pada dibuku saja, karena 
dengan siswa mencari sendiri maka siswa akan mudah untuk mengingat-ingat, seperti beliau katakan pada saat wawancara dengan peneliti :

"Selain alat musik media nya internet, anak-anak saya perbolehkan untuk buka internet. Bawa laptop bisa, tablet bisa, smartphone pun tidak masalah, tetapi tetep saya kontrol pembatabas pemakaiannya.lebih ke teori, teori musik dan sebagainya biar tau sendiri, jadi cari tau sendiri dan mempresentasikan sendiri. Oh... ternyata not seperenambelasan kayak gitu."

Selain materi pembelajaran guru juga mempersiapkan media pembelajaran. Media pembelajaran yang dipergunakan merupakan media audio visual berupa LCD, sound/pengeras suara dan laptop/komputer. Sesuai dengan pengertian media audio visual yang dijelaskan oleh Hujair AH Sanaky (2013 : 119) bahwa alat-alat yang dapat memproyeksikan gambar bergerak dan bersuara. Media pembelajaran selain audio visual juga dipergunakan seperti alat musik dan alat elektronik.

\subsubsection{Tahap Pelaksanaan/Proses Pembelajaran}

Peneliti sudah melakukan penelitian tentang penggunaan media audio visual dalam pembelajaran seni budaya sub materi musik di SMK Negeri 03 Salatiga. Penelitian ini dilakukan pada kelas $\mathrm{X}$ jurusan ototranika dan teknik sepeda motor dikarenakan jurusan tersebut yang mendapatkan mata pelajaran seni budaya sub materi musik yang diampu oleh bapak Sulistyo. Peneliti dalam melakukan penelitian fokus pada proses pembelajaran seni musik di tiga kelas. Proses pembelajaran di kelas terdapat kegiatan pembelajaran dan komponenkomponen pembelajaran yang akan dibahas sebagai berikut. 


\subsubsection{Kegiatan dalam Pembelajaran Seni Budaya Sub Materi Musik di SMK Negeri 03 Salatiga}

\section{(1) Kegiatan Pendahuluan}

Persiapan yang dilakukan sebelum kegiatan proses pembelajaran adalah mempersiapkan media audio visual yang akan digunakan. Penggunaan media pembelajaran sangatlah membantu dalam proses belajar-mengajar, seperti pengertian media menurut Atwi Suparman (1997), mendefinisikan media merupakan alat yang digunakan untuk menyalurkan pesan atau informasi dari pengirim kepada penerima pesan. Guru meminta bantuan kepada siswa untuk mengambil dan mempersiapkan media yang akan digunakan. Kegiatan pertama merupakan kegiatan yang bertujuan untuk menyiapkan siswa untuk siap mengikuti proses pembelajaran. Kegiatan ini guru melakukan kegiatan membuka pembelajaran. Membuka pelajaran adalah untuk memperkenalkan hal-hal yang akan dipelajari agar siswa memiliki ketertarikan, merasa ingin tahu dan memiliki kemauan untuk mempelajari materi (Khakiim 2016). Seorang guru mempunyai cara masing-masing untuk membuka pembelajaran, supaya siswa dapat fokus kedepan untuk menerima materi yang akan disampaikan. Setelah media pembelajaran sudah siap, kegiatan pembelajaran dibuka dengan salam dan guru menanyakan materi minggu lalu kepada siswa dengan tujuan mengingat-ingat kembali materi yang telah disampaikan. Sesuai dengan pengertian dari metode tanya jawab merupakan proses penyampaian guru melakukan kegiatan bertanya dan murid menjawabnya begitu juga sebaliknya. 


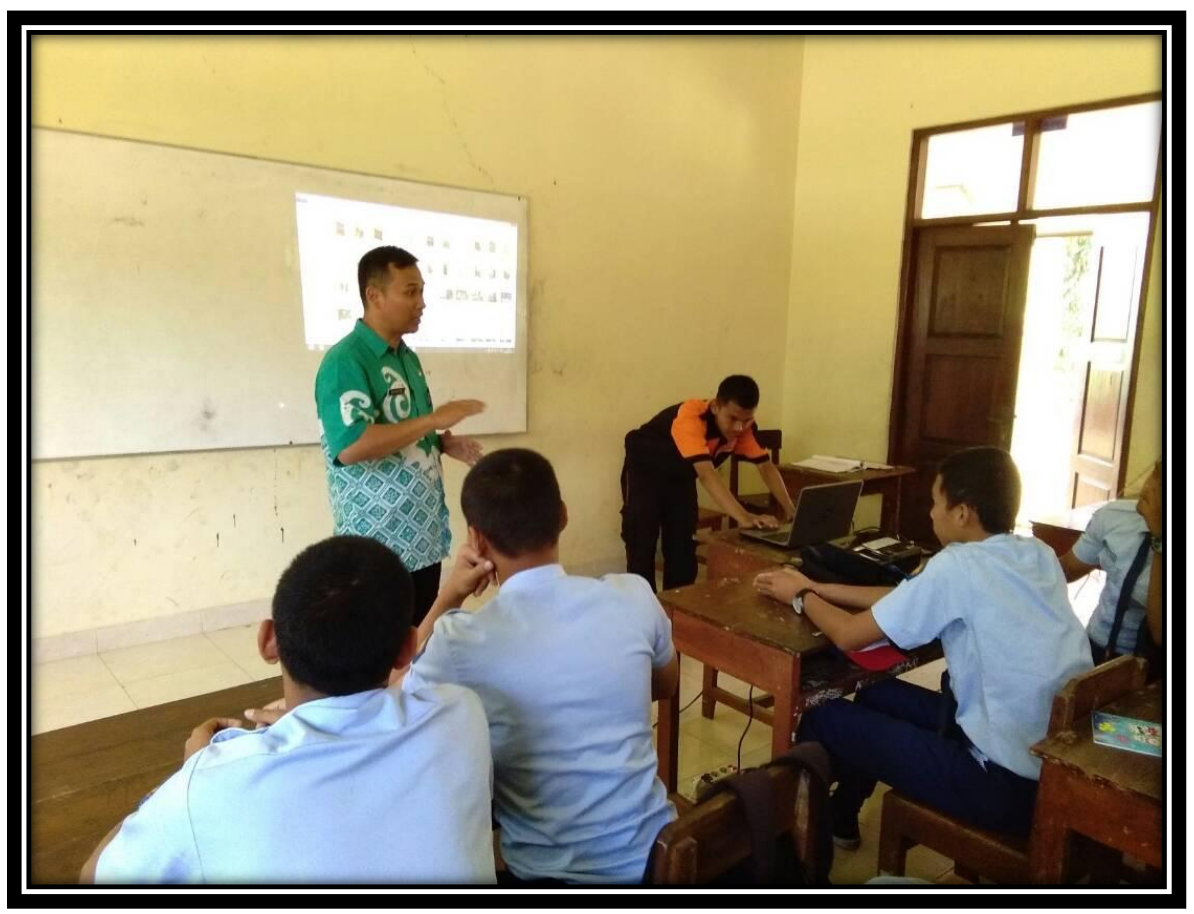

Foto 4.3

Guru Melakukan Pembukaan Pembelajaran

(Sumber: Angga Dwi Winarno, Mei 2017)

Kegiatan ini direspon baik dengan siswa, karena siswa langsung menjawab pertanyaan dari guru dan membuat suasana kelas menjadi aktif dan kondusif. Sesuai dengan dokumentasi pada foto 4.3, guru sedang melakukan kegiatan membuka pembelajaran dan meminta bantuan salah satu siswa untuk mempersiapkan media pembelajaran yang akan digunakan yaitu media audio visual. Kegiatan pembukan ini guru juga menggunakan metode ceramah untuk menjelaskan apa yang akan disampaikan kepada siswa. Didalam pengertiannya metode ceramah diartikan sebagai proses penyampaian informasi dengan jalan mengeksplanasi atau menuturkan sekelompok materi secara lisan dan pada saat yang sama materi itu diterima oleh sekelompok subjek. 
Kegiatan guru berikutnya yaitu memperlihatkan contoh video-video pementasan seni didalam ruangan dan luar ruangan kepada siswa dengan tujuan apresiasi siswa terhadap seni. Guru menggunakan media audio visual dikarenakan efektif dan efisien dalam penggunaan media tersebut. Sesuai dengan fungsi dari media audio visual menurut Nana Sudjana (1991), yaitu penggunaan media dalam pengajaran lebih diutamakan untuk membantu siswa dalam menangkap pengertian yang diberikan guru secara cepat dalam proses belajar mengajar. Menurut Hujair

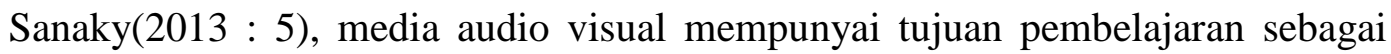
alat bantu dalam proses belajar-mengajar dan meningkatkan efisiensi proses pembelajaran. Hal tersebut juga diutarakan guru saat wawancara mengenai media audio visual sebagai berikut :

"efektifnya yaitu siswa langsung melihat langsung, merasakan, melihat mendengar. Kalo dibuku kurikulum 2013 itu kan ada juga sih...materi pementasan, contoh-contoh panggung di outdoor ataupun di indoor itu kan hanya sebatas tau gambarannya, tapi kalo menggunakan media audio visual kan bisa kompleks."

Video pementasan seni yang pertama yaitu sajian musik festival band pelajar yang di diadakan oleh Universitas Kristen Satya Wacana (UKSW) yang berada didalam ruangan. Saat proses pemutaran video siswa memperhatikan dan saling berdiskusi dengan temannya, namun ada juga yang tidak memperhatikan dan terlihat bosan dengan pemutaran video menggunakan media audio visual tersebut. Video yang kedua yaitu pementasan seni tari, pementasan seni tari ini juga bertempatan di Universitas Kristen Satya Wacana (UKSW). Pementasan seni tari tersebut memadukan tari modern dan tari tradisional yang diperpadukan sehingga menampilkan tarian yang indah. Waktu pemutaran video kedua ini siswa 
sudah terlihat bosan ditandai dengan bersikap duduk yang tidak baik saat melihat video tersebut. Sesuai dengan dokumentasi foto 4.4, siswa terlihat antusias saat pemutaran video pementasan, namun ada juga siswa yang merasa bosan dengan tanda sikap duduk yang kurang benar. Video yang terakhir yaitu pementasan seni musik yang ada di luar ruangan. Bapak Sulistyo memberikan contoh video pementasan musik drumblek saat ujian akhir semester pergelaran kelas XII yang diadakan di lapangan SMK Negeri 03 Salatiga. Tujuan dari pemutaran video pementasan seni dengan bantuan media audio visual, agar siswa dapat belajar apa yang telah mereka lihat, sehingga menjadi inspirasi atau ide dalam pementasan pergelaran seni budaya yang akan ditampilkan. Hal ini sama dengan pengertian tentang belajar pada hakikatnya adalah "perubahan" yang terjadi pada diri seseorang setelah melakukan aktivitas tertentu (Pupuh dan Sobry 2007 : 6). Belajar yang terpenting merupakan sebuah proses yang telah dialami bukan hanya hasil yang diperoleh.

Pemutaran contoh pementasan seni dengan menggunakan media audio visual ini dilakukan guru selama kurang lebih 1 jam pelajaran, selanjutnya siswa dipersilahkan mengatur persiapan mempergelarkan seni musik. Persiapan dari penataan panggung dari meja, dekorasi, kostum perkelompok dan peralatan yang digunakan saat pementasan. Semua persiapan dilakukan semua siswa dengan antusias dengan alokasi waktu pembelajaran 4 jam pelajaran, maka pembelajaran tidak terasa dikejar-kejar oleh waktu. 


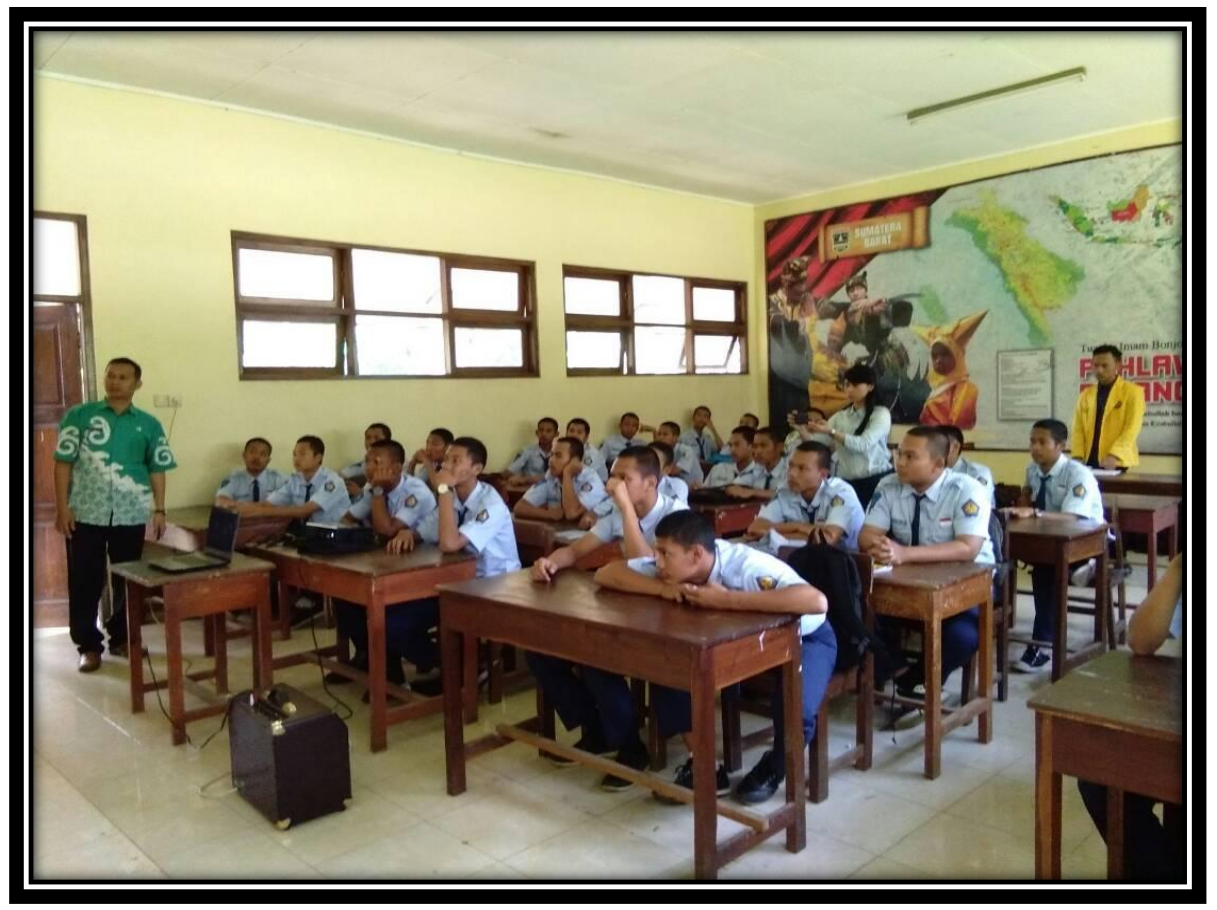

Foto 4.4

Keadaan Saat Mengamati Contoh Pementasan Seni (Sumber : Angga Dwi Winarno, Mei 2017)

\section{(2) Kegiatan Inti}

Tahap kedua ini disebut juga tahap inti pembelajaran, dimana pada tahap ini guru mengarahkan siswa untuk masuk ke materi dalam proses pembelajaran. Kegiatan inti merupakan proses pembelajaran untuk mencapai kompetensi dasar yang dilakukan secara interaktif, inspiratif, menyenangkan, menantang, memotivasi siswa untuk berpartisipasi aktif, serta memberikan ruang yang cukup bagi prakarsa, kreativitas, dan kemandirian sesuai dengan bakat, minat dan perkembangan fisik serta psikologis peserta didik (Rusman 2013 : 11) Selesai pada kegiatan pendahuluan dengan memperhatikan contoh-contoh pementasan seni dengan bantuan media audio visual bapak Sulistyo mengarahkan siswa 
kemateri dengan kompetensi dasar mempergelarkan musik dengan memperhatikan nilai-nilai estetis.

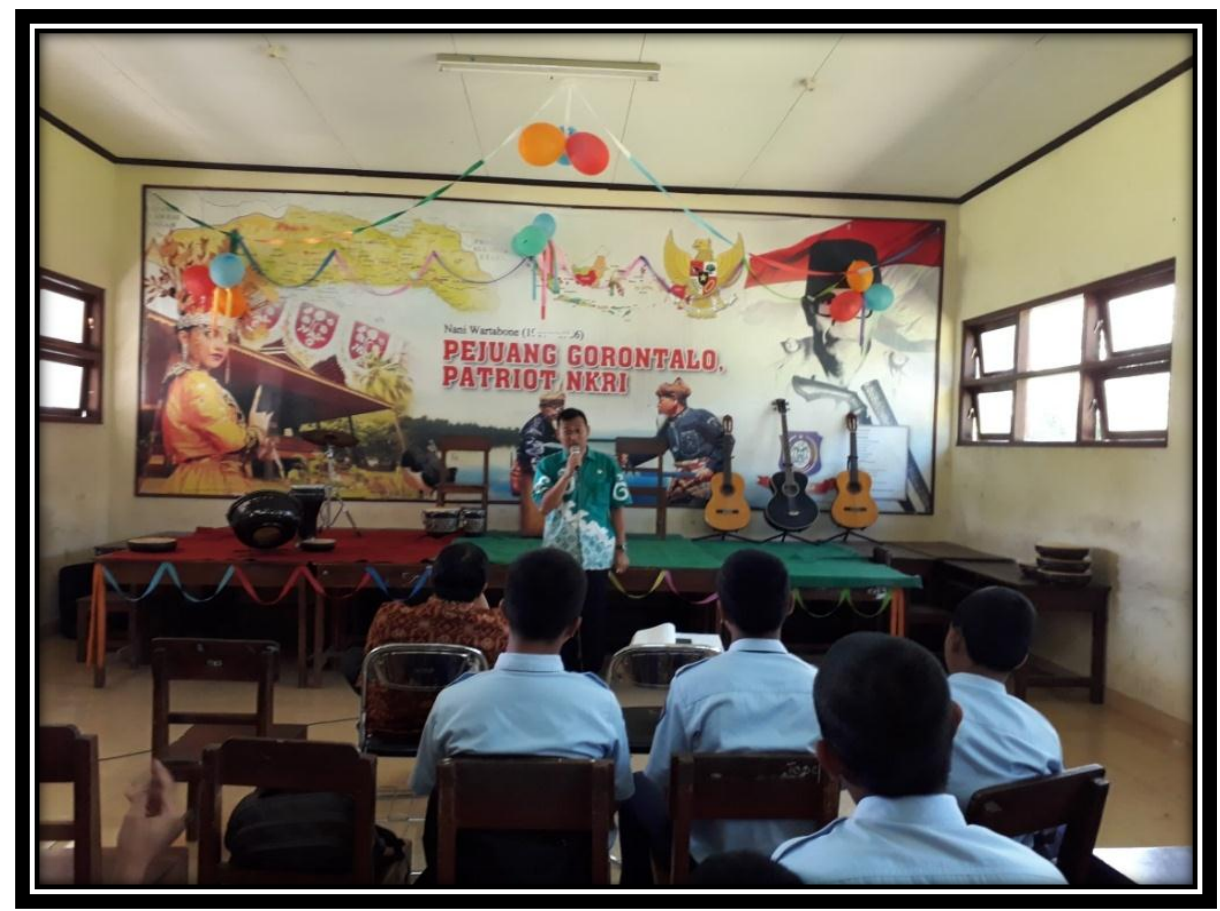

Foto 4.5

Keadaan Saat Guru Membuka Pergelaran Seni (Sumber : Angga Dwi Winarno, Mei 2017)

Setelah persiapan telah selesai semua, perwakilan dari siswa memberi tahu kepada guru bahwa persiapan pergelaran musik sudah selesai. Sebelum memulai pementasan bapak Sulistyo memberikan arahan terlebih dahulu dan siswa mendengarkan, setelah itu bapak sulistyo mempersilahkan untuk memulai pementasannya. Sesuai dengan dokumentasi foto 4.5 , guru terlihat memberikan arahan kepada siswa dan siswa memperhatikan apa yang disampaikan oleh bapak Sulistyo. 
Salah satu siswa memimpin jalannya pementasan seni musik yang sudah ditunjuk sebagai MC. Proses pementasan ini tidak hanya seni musik saja, menurut bapak Sulistyo karena mata pelajaran seni budaya, maka siswa dibebaskan untuk mempergelarkan sajiannya masing-masing yang sudah dipersiapkan dengan kelompok. Masing-masing kelompok saling menanpilkan sajiannya dan kelompok lain mengapresiasi penampilan teman-temannya. Sajian dari pergelaran seni budaya tersebut bermacam-macam seperti seni musik, seni tari ada juga seni drama. Selama penampilan sajian yang ditampilkan oleh kelompok masingmasing banyak sekali hal-hal yang lucu karena tingkah laku siswa yang kurang persiapan dan juga siswa yang sengaja mengganggu kelompok yang sedang tampil, menjadikan suasana yang tidak tegang dan menghibur namun tetap kondusif saat pergelaran seni budaya.

Foto 4.6 merupakan hasil studi dokumentasi proses bagaimana proses pergelaran seni budaya berlangsung. Salah satu kelompok sedang menampilkan sajian musik rebana lengkap dengan kostumnya yang sesuai dengan sajian musiknya dipilih. Difoto 4.6 terlihat beberapa anak memainkan alat musik rebana yang terlihat kompak dan salah satu dari mereka menyanyikan lagu-lagu pujian Islami. 


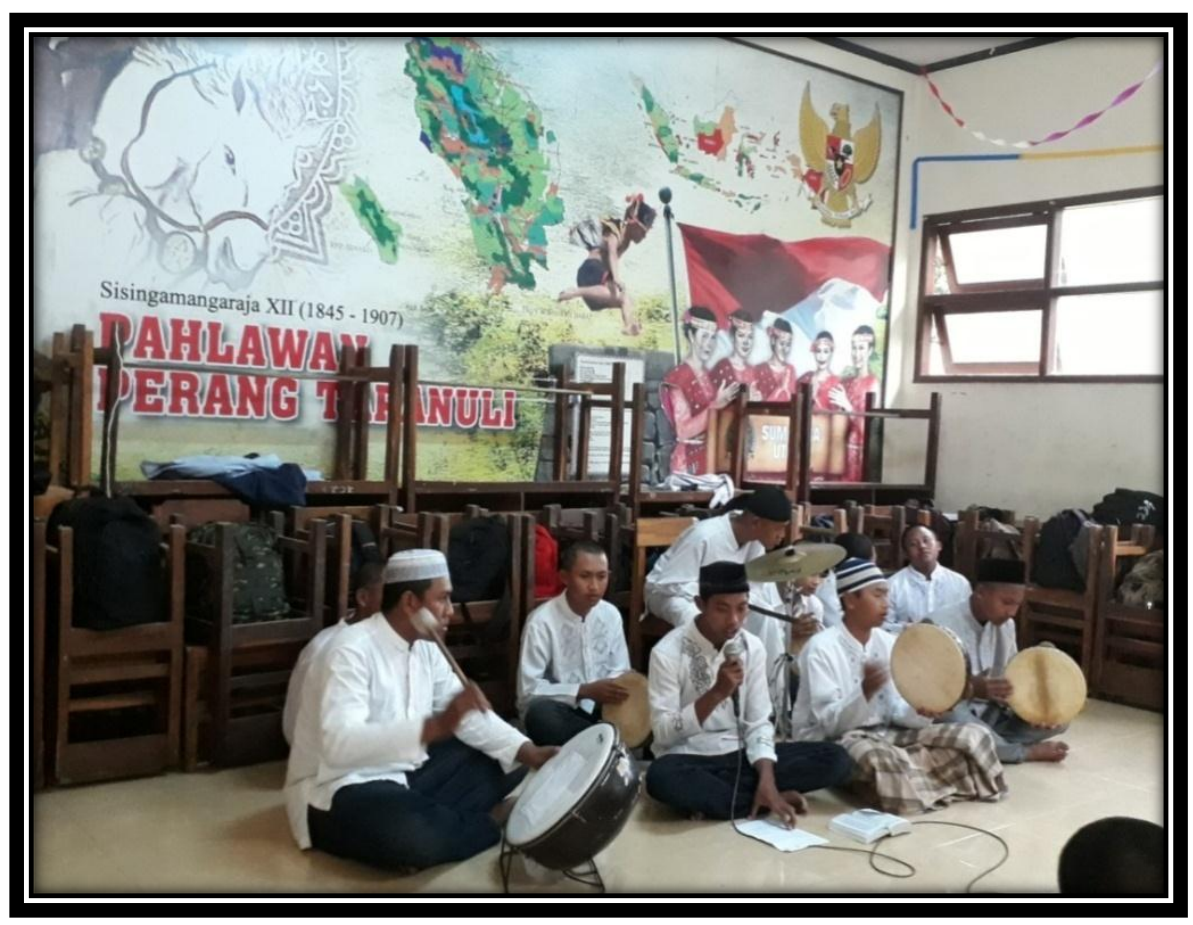

Foto 4.6

Proses Pergelaran Seni Budaya

(Sumber : Angga Dwi Winarno, Mei 2017)

\section{(3) Kegiatan Penutup}

Tahap ini merupakan kegitan guru menutup pelajaran, dengan mengalokasikan waktu 10 menit untuk membuat rangkuman/simpulan pelajaran bersama dengan siswa. Rangkuman diberikan bertujuan agar siswa dapat lebih mengerti materi yang telah dipelajari. Sesuai dengan pendapat Rusman (2013 : 92), kegiatan menutup pelajaran dimaksud untuk memberikan gambaran menyeluruh tentang apa yang telah dipelajari oleh siswa, mengetahui tingkat pencapaian siswa dan tingkat keberhasilan guru dalam proses pembelajaran.

Guru juga memberikan apresiasi kepada siswa yang telah menampilkan pergelaran seni secara berkelompok. Bapak Sulistyo mengucapkan terima kasih karena sudah menampilkan sajian yang baik dan variatif, karena mayoritas semua 
bidang seni ada semua dari seni musik, tari dan drama. Bapak Sulistyo juga menjelaskan kepada siswa bahwa pergelaran ini akan ada lagi pada kelas XII yang lebih besar dan di panggung terbuka, penampilan per sajian sudah tidak dibagi kelompok kecil namun sudah per kelas diikuti semua kelas XII. Kegiatan terakhir yang dilakukan guru yaitu guru memimpin doa penutup dan mengakhiri pertemuan tersebut dengan salam.

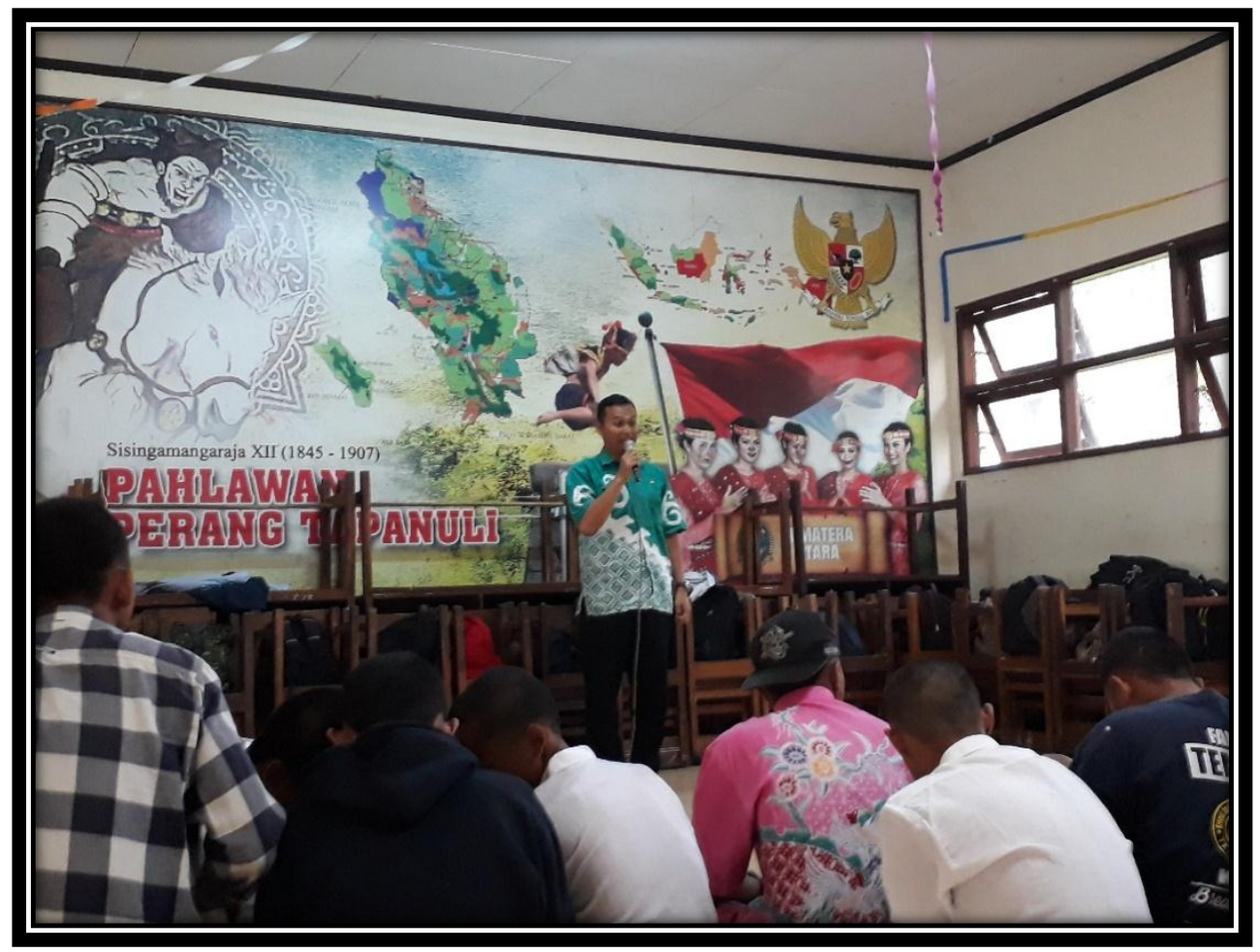

Foto 4.7

Guru Melakukan Menutup Pelajaran (Sumber : Angga Dwi Winarno, Mei 2017)

\subsubsection{Evaluasi Pembelajaran}

Tahap evaluasi seorang guru dituntut memiliki kemampuan dalam menentukan pendekatan dan cara-cara evaluasi, penyusunan alat-alat evaluasi, pengolahan dan penggunaan hasil evaluasi. Dalam tahap evaluasi guru 
memberikan rangkuman materi yang telah dipelajari kepada siswa, guru mempersilahkan kepada siswa untuk bertanya materi yang belum paham sebelum proses pembelajarann berakhir. Sama halnya dengan pendapat Rusman (2013 : 78), evaluasi pembelajaran merupakan kegiatan atau cara yang ditujukan untuk mengetahui tercapainya atau tidaknya tujuan pembelajaran dan juga proses pembelajaran yang telah dilakukan. Dalam tahap ini guru juga mengajak siswa untuk berdiskusi tentang apa saja yang dapat dipelajari tentang materi mempergelarkan musik dengan memperhatikan nilai-nilai estetis.

Dari penggunaan media audio visual dalam pembelajaran seni budaya khususnya seni musik dengan kompetensi dasar mempergelarkan musik dengan memperhatikan nilai-nilai estetis sangat efektif dan efesian, karena selain membantu guru untuk memberikan contoh pementasan didalam ruangan maupun diluar ruangan, media audio visual juga berdampak langsung kepada siswa untuk mendapatkan inspirasi apa yang akan mereka sajikan saat pergelaran seni. Tahap evaluasi guru juga memberikan penilaian berupa tugas individu, tugas tersebut berupa apresiasi tentang kelompok lain yang telah menampilkan sajiannya saat pergelaran seni budaya berlangsung. 


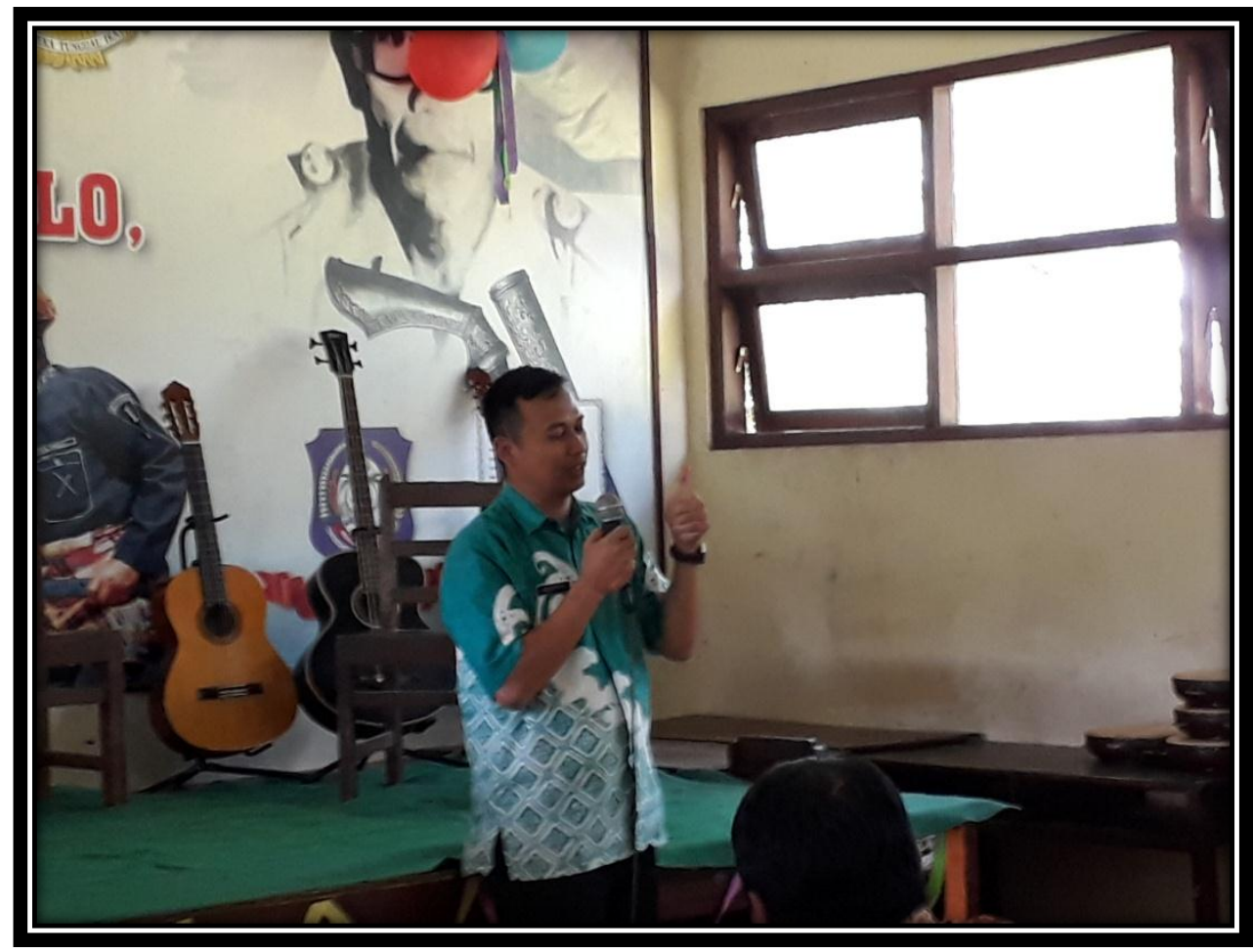

Foto 4.8

Guru Melakuan Evaluasi Pembelajaran

(Sumber : Angga Dwi Winarno, Mei 2017) 


\section{BAB V \\ PENUTUP}

\subsection{Simpulan}

Simpulan yang dapat disampaikan peneliti berdasarkan penelitian yang sudah dilakukan tentang penggunaan media audio visual dalam pembelajaran seni budaya sub materi musik di SMK Negeri 03 Salatiga.

Persiapan yang perlu disiapkan sebelum melaksanakan pembelajaran seni budaya sub materi musik di SMK Negeri 03 Salatiga adalah mengembangkan silabus, menyusun Rencana Pelaksanaan Pembelajaran (RPP), dan menyiapkan materi dan media pembelajaran. Silabus yang telah ditetapkan oleh pemerintah dikembangkan guru untuk dijadikan acuan dalam penyusunan RPP. Penyusunan Rencana Pelaksanaan Pembelajaran yang mengacu pada silabus juga mengacu pada keadaan siswa dan lingkungan sekolah. Guru menyusun RPP nantinya akan menjadi pedoman dalam melaksanakan pembelajaran seni budaya sub materi musik di kelas. Didalam penyusunan RPP, guru juga menyiapkan materi-materi dan media yang ada didalam RPP yang sudah dibuat.

Media pembelajaran audio visual digunakan guru sebagai alat untuk membantu proses dalam pembelajaran seni budaya sub materi musik. Tahap pelaksanaan pembelajaran seni budaya sub materi musik di kelas $\mathrm{X}$ jurusan ototronika dan teknik sepeda motor. Penggunaan media audio visual digunakan untuk memberikan contoh pementasan seni musik didalam ruangan dan diluar ruangan dengan tujuan agar siswa dapat paham dan mendapatkan inspirasi untuk 
rancangan pergelaran musik, sesuai dengan Kompetensi Dasar (KD) yang ada yaitu memahami rancangan pergelaran musik dan prakteknya mempergelarkan musik dengan memperhatikan nilai-nilai estetis.

Tahap evaluasi yang guru lakukan yaitu memberikan apresiasi kepada kelompok yang sudah mempergelarkan seni dan mengevaluasi masing-masing kelompok. Guru juga bertanya kepada siswa setelah pembelajaran selesai tentang apa saja pembelajaran yang bisa diambil dari materi pergelaran musik tersebut. Pada akhir pertemuan guru memberikan tugas individu untuk menilai penampilan pergelaran seni kelompok lain yang telah disaksikan.

\subsection{Saran}

Saran yang dapat peneliti berikan berdasarkan simpulan dalam penelitian tentang penggunaan media audio visual dalam pembelajaran seni budaya sub materi musik di SMK Negeri 03 Salatiga adalah sebagai berikut.

Saran yang pertama berkaitan dengan tahap perencanaan pembelajaran seni budaya sub materi musik di SMK Negeri 03 Salatiga sebaiknya guru membuat Rencana Pelaksanaan Pemebelajaran (RPP) medianya tidak hanya menayangkan video seni saja untuk contoh pergelaran musik. Guru juga harus mempratekkan secara langsung kepada siswa, supaya proses pembelajaran tidak hanya memanfaatkan media audio visual saja.

Saran yang kedua, guru sebaiknya mengembangkan silabus lebih baik lagi, karena dalam pembuatan RPP didalam pelaksanaannya terlalu banyak waktu untuk siswa latian mempersiapkan pergelaran musik. Selain itu, guru terkadang 
meninggalkan siswa pada waktu berdiskusi mempersiapkan pergelaran musik. Sebaiknya guru tetap memperhatikan siswa supaya kondisi kelas tetap kondusif.

Tahap evaluasi ini guru sudah sesuai dengan tahapan yang ada dan kegiatan tersebut dapat dipertahankan, jadi peneliti tidak memberikan saran pada tahap evaluasi. Peneliti berharap supaya dari pihak sekolah dapat memperbaiki sarana prasarana yang menunjang dalam proses pembelajaran. 


\section{DAFTAR PUSTAKA}

Arikunto, Suharsimi. 2014. Prosedur Penelitian, Suatu Pendekatan Praktik. Jakarta: PT. Rineka Cipta.

Arsyad, Azhar. 2014. Media Pembelajaran. Jakarta: Kharisma Putra Utama Ambarwangi, Sri; Suharto, Suharto. Reog as Means of Students' Appretiationand Creation in Arts and Culture Based on the Local Wisdom. Harmonia: Journal of Arts Research and Education, [S.1.], v. 14, n. 1, p. 37-45, Mar. 2014. ISSN 2541-2426. Available at: <https://journal.unnes.ac.id/nju/index.php/harmonia/article/view/2789>. Date accessed: $17 \quad 2018$. doi:http://dx.doi.org/10.15294/harmonia.v14i1.2789.

Suharto, S., \& Aesijah, S. (2014). THE LESUNG MUSIC IN THE VILLAGE OF LEDOK BLORA REGENCY. Harmonia: Journal Of Arts Research And Education, 14(1), 65-71. doi:http://dx.doi.org/10.15294/harmonia.v14i1.2851

Handayaningrum, W. (2016). Science-Based Thematic Cultural Art Learning in Primary School (2013 Curriculum). Harmonia: Journal Of Arts Research And Education, 16(1), 14-23. doi:http://dx.doi.org/10.15294/harmonia.v16i1.6766

Suharto, S. (2013). PROBLEMATIKA PELAKSANAAN PENDIDIKAN SENI MUSIK DI SEKOLAH KEJURUAN NON SENI. Harmonia: Journal Of Arts Research And Education, 12(1). doi:http://dx.doi.org/10.15294/harmonia.v12i1.2221

Suharto, S. (2000). ACTION RESEARCH TO SOLVE MUSIC TEACHING PROBLEMS IN THE SCHOOL. Harmonia: Journal Of Arts Research And Education, 1(1). doi:http://dx.doi.org/10.15294/harmonia.v1i1.835

Suharto, S. (2011). PENGEMBANGAN MATERI DAN KEGIATAN PEMBELAJARANNYA DALAM KURIKULUM TINGKAT SATUAN PENDIDIKAN BIDANG SENI MUSIK. Harmonia: Journal Of Arts Research And Education, 8(3). doi:http://dx.doi.org/10.15294/harmonia.v8i3.780

Kusumadewi, L., \& Suharto, S. (2011). PENINGKATAN HASIL BELAJAR SENI MUSIK DENGAN MEDIA AUDIO VISUAL MELALUI METODE BERVARIASI. Harmonia: Journal Of Arts Research And Education, 10(2). doi:http://dx.doi.org/10.15294/harmonia.v10i2.63 Offset.

Daryanto. 2010. Media Pembelajaran. Bandung: Satu Nusa. 
Deykisy, Shadila. 2013. Pengunaan Media Audio Visual Dalam Pembelajaran Lagu Setempat Untuk Motivasi Belajar Siswa di SMK 1 Negeri Ranah $\begin{array}{lllll}\text { Pesisir. } & \text { Diunduh } & 30 & \text { Januari } & 2017\end{array}$ (http://ejournal.unp.ac.id/index.php/sendratasik/article/view/4469/0).

Fathurohman, Pupuh dan M. Sobry Sutikno. 2007. Strategi Belajar Mengajar. Bandung: PT Refika Aditama Bandung.

Hariyanto. 2014. Metode Pembelajaran. http://belajarpsikologi.com/. Diakses pada 22 Juli 2017.

http://andantemusica-royal.blogspot.co.id/2011/03/analisis-komposisimusikal.html (22 Agustus 2017)

http://tu.laporanpenelitian.com/2014/12/37.html?m=1 (31 Maret 2017)

http://www.eurekapendidikan.com/2014/12/pendekatan-pembelajaran.html?=1 $\quad$ (2 April 2017)

Jamalus. 1988. Pengajaran Musik Melalui Pengalama Musik. Jakarta: Departemen Pendidikan dan Kebudayaan. Direktorat Jendral Pendidikan Tinggi. LPTK.

Joseph, Wagiman. 2012. Teori Musik 1. Semarang: Fakultas Bahasa dan Seni.

J.Angio, Desri. 2014. Kreativitas Guru dalam Menerapkan Media Audio Visual pada Pembelajaran IPA di SDN Bualemo Kabupaten Gorontalo Utara. Diunduh 04 Februari 2017 dari (http://eprints.ung.ac.id/10038/).

Khakiim, Uluul. 2016. Pelaksanaan Membuka dan Menutup Pelajaran oleh Guru Kelas 1 Sekolah Dasar. Diunduh 22 Agustus 2017 dari (http://journal.um.ac.id/index.php/jptpp/article/view/6738/2931).

Kusumadewi, Lidya Fita. 2010. Peningkatan Hasil Belajar Seni Musik dengan Media Audio Visual Melalui Metode Bervariasi. Diunduh 08 Maret 2017

(https://journal.unnes.ac.id/nju/index.php/harmonia/article/view/63/382 2).

Lukman Bachtiar, Chamdani. 2013. Media Pembelajaran Audio Visual Terhadap Pembelajaran Lompat Jauh Pada Siswa Kelas IV SDN Grobogan 04 Kabupaten Grobogan. Dalam Skripsi S-1 Program Studi Pendidikan Seni Musik. Universitas Negeri Semarang.

Oktira, Yona Syaida. 2013. Penggunaan Media Audio Visual untuk Meningkatkan Kemandirian Siswa Belajar Seni Budaya. Diunduh 18 Maret 2017 dari (http://download.portalgaruda.org/article.php?article=101215\&val=153 8). 
Raco. 2010. Metode Penelitian Kualitatif Jenis, Karakteristis dan Kegunaannya. Jakarta: PT. Gramedia Widiasarana Indonesia Kompas Gramedia Building.

Riduwan. 2015. Belajar Mudah Penelitian Untuk Guru-Karyawan dan Peneliti Pemula. Bandung: CV. Alfabeta.

Rifa'i RC, Achmad dan Catharina Tri Anni. 2012. Psikologi Pendidikan. Semarang: UPT UNNES PRESS.

Rusman. 2013. Model-Model Pembelajaran: Pengembangkan Profesionalisme Guru. Jakarta: Rajawali Pers.

Sadiman, Arief S, dkk. 2014. Media Pendidikan: Pengertian, Pengembangan, dan Pemanfaatannya. Jakarta: Rajawali Pers.

Sanaky, Hujair. 2013. Media Pembelajaran Interaktif-Inovatif. Yogyakarta: Kaukaba Dipantara.

Sanjaya, Wina. 2008. Strategi Pembelajaran: Berorientasi Standar Proses Pendidikan. Jakarta: Kencana Prenada Media Group.

Sugianti Rahayu, Novi. 2013. Peningkatan Ketrampilan Menyanyikan Melalui Model Direct Instruction Berbantu Media Audio Visual Pada Siswa Kelas IV SDN Sampangan 01 Semarang. Dalam Skripsi S-1 Program Studi Pendidikan Seni Musik. Universitas Negeri Semarang.

Sugiono. 2013. Metode Penelitian Kuantitatif, Kualitatif, dan R\&D. Bandung: Alvabeta.

Sugiono. 2015. Metode Penelitian Kuantitatif, Kualitatif, dan Kombinasi (Mixed Methods). Bandung: Alvabeta.

Wena, Made. 2009. Strategi Pembelajaran Inovatif Kontemporer. Jakarta Timur: PT Bumi Angkasa 
LAMPIRAN 
Lampiran 1

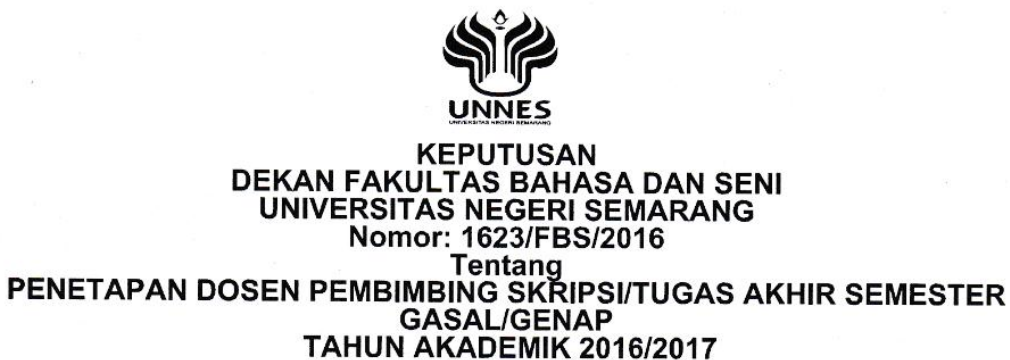

Menimbang : Bahwa untuk memperlancar mahasiswa Jurusan/Prodi Seni Drama, Tari, dan Musik/Pend. Sendratasik Fakultas Bahasa dan Seni membuat Skripsi/Tugas Akhir, maka perlu menetapkan Dosen-dosen Jurusan/Prodi Seni Drama, Tari, dan Musik/Pend. Sendratasik Fakultas Bahasa dan Seni UNNES untuk menjadi pembimbing.

Mengingat : 1. Undang-undang No.20 Tahun 2003 tentang Sistem Pendidikan Nasional (Tambahan Lembaran Negara RI No.4301, penjelasan atas Lembaran Negara RI Tahun 2003, Nomor 78)

2. Peraturan Rektor No. 21 Tahun 2011 tentang Sistem Informasi Skripsi UNNES

3. SK. Rektor UNNES No. 164/O/2004 tentang Pedoman penyusunan Skripsi/Tugas Akhir Mahasiswa Strata Satu (S1) UNNES;

4. SK Rektor UNNES No.162/O/2004 tentang penyelenggaraan Pendidikan UNNES:

Menimbang : Usulan Ketua Jurusan/Prodi Seni Drama, Tari, dan Musik/Pend. Sendratasik Tanggal 26 Oktober 2016

Menetapkan

\section{MEMUTUSKAN}

PERTAMA : Menunjuk dan menugaskan kepada:

1. Nama : Dr. WADIYO, M.Si

NIP : 195912301988031001

Pangkat/Golongan : IV/c

Jabatan Akademik : Lektor Kepala

Sebagai Pembimbing I

2. Nama : Mochammad Usman Wafa, S.Pd., M.Pd.

NIP : 198012042015041001

Pangkat/Golongan : -

Jabatan Akademik : Tenaga Pengajar

Sebagai Pembimbing II

Untuk membimbing mahasiswa penyusun skripsi/Tugas Akhir :

Nama : : Angga Dwi Winarno

NIM : 2501413055

Jurusan/Prodi $\quad$ : Seni Drama, Tari, dan Musik/Pend. Sendratasik

Topik : TUJUAN DAN FUNGSI ACARA PARADE MUSIK GEREJAWI DI GEREJA INJILI DI TANAH JAWA (GITJ) PATI

KEDUA : Keputusan ini mulai berlaku sejak tanggal ditetapkan.

Tembusan DITETAPKAN DI : SEMARANG

1. Pembantu Dekan Bidang Akademik 2016

2. Ketua Jurusan

3. Petinggal

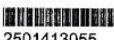

2501413055

....: FM-03-AKD-24/Rev. 00 :.... 


\title{
Lampiran 2
}

\section{(1) KEMENTERIAN RISET, TEKNOLOGI, DAN PENDIDIKAN TINGGI UNIVERSITAS NEGERI SEMARANG \\ FAKULTAS BAHASA DAN SENI \\ Gedung B, Kampus Sekaran, Gunungpati, Semarang 50229 \\ UNNES Telepon +62248508010, Faksimile +62248508010 Laman: http://fbs.unnes.ac.id, Email: fbs@unnes.ac.id}

\author{
Nomor : 3504/UN37.1.2/LT/2017 \\ Lamp. :- \\ Hal. : Permohonan Izin Penelitian
}

Yth. Kepala SMK Negeri 3 Salatiga

di tempat

Dengan hormat kami beritahukan bahwa dalam rangka penyusunan skripsi mahasiswa kami,

\section{nama}

nim

jurusan

program studi

jenjang

tahun akademik

judul

\section{Angga Dwi Winarno}

: 2501413055

: Pendidikan Seni Drama,Tari dan Musik

Pendidikan Seni Musik

: S1

: 2016/2017

Penggunaan Media Audio Visual dalam Pembalajaran Seni Budaya Sub Materi Musik di SMK Negeri 03 Salatiga.

akan mengadakan penelitian di SMK Negeri 3 Salatiga, waktu pelaksanaan N"ei - Juni 2017. Untuk itu kami mohon Saudara berkenan memberikan izin kepada mahasiswa di atas untuk keperluan tersebut.

Atas perhatian dan kerja sama Saudara, kami sampaikan terima kasih.

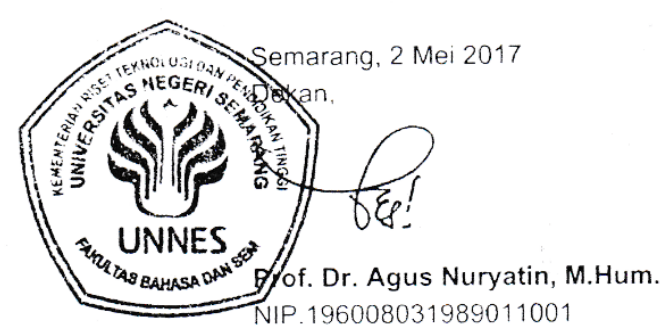

Tembusan:

1. Pembantu Dekan Bidang Akademik

2. Ketua Jurusan

3. Pertinggal

FM-05-AKD-24 


\section{PEMERINTAH PROVINSI JAWA TENGAH \\ DINAS PENDIDIKAN DAN KEBUDAYAAN SEKOLAH MENENGAH KEJURUAN NEGERI 3 \\ SALATIGA}

Jl. Jafar Shodiq, Kalibening, Tingkir, Kota Salatiga Kode Pos 50744 Telepon 0298-3418850

Faksimile 0298-3418850 Surat Elektronik : smkn3salatiga@gmail.com

$\begin{array}{lll}\text { Nomor } & : & 423.4 / 2391 / 003 \\ \text { Lamp. } & : & - \\ \text { Perihal } & - & \text { Ijin Penelitian }\end{array}$

28 Juli 2017

Kepada

Yth.

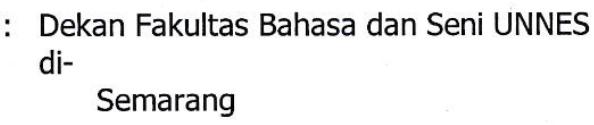

Menindaklanjuti surat Saudara Nomor : 3504/UN37.1.2/LT/2017 tertanggal 2 Mei 2016, perihal seperti pada pokok surat, maka dapat kami sampaikan bahwa mahasiswa tersebut di bawah ini :

\begin{tabular}{|c|c|c|l|}
\hline No. & \multicolumn{1}{|c|}{ Nama } & \multicolumn{1}{c|}{ NIM } & \multicolumn{1}{c|}{ Jurusan } \\
\hline 1. & Angga Dwi Winarno & 2501413055 & $\begin{array}{l}\text { Fakultas Seni Drama, } \\
\text { Tari, dan Musik }\end{array}$ \\
\hline
\end{tabular}

Telah melakukan Penelitian untuk penyusunan Skripsi/ Tugas Akhir di SMK Negeri 3 Salatiga, dengan judul "Penggunaan Media Audio Visual Dalam Pembelajaran Seni Budaya Sub Materi Musik di SMK Negeri 3 Salatiga" pada bulan Mei - Juni 2017 s.d. selesai.

Demikian yang dapat kami sampaikan atas perhatian dan kerjasamaanya yang baik kami ucapkan terima kasih.

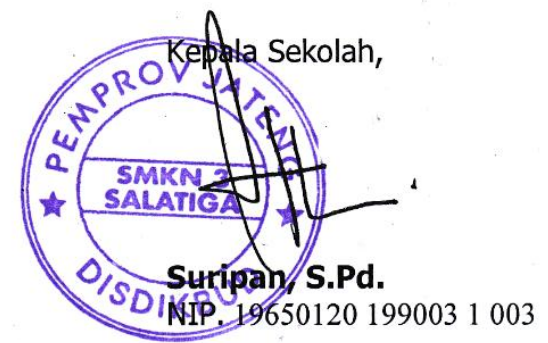


Lampiran 3

PEDOMAN OBSERVASI

PENGGUNAAN MEDIA AUDIO VISUAL DALAM PEMBELAJARAN

SENI BUDAYA SUB MATERI MUSIK DI SMK NEGERI 03 SALATIGA

\section{Oleh : Angga Dwi Winarno}

\section{Pokok-Pokok Pedoman Observasi}

1.1 Proses pembelajaran seni budaya sub materi musik pada kelas X SMK Negeri

03 Salatiga, meliputi:

1.1.1 Elemen-elemen pembelajaran, meliputi:

1.1.1.1 Kegiatan pendahuluan

1.1.1.2 Kegiatan inti

1.1.1.3 Kegiatan penutup

1.1.2 Komponen-komponen pembelajaran, meliputi :

1.1.2.1 Tujuan pembelajaran

1.1.2.2 Materi pembelajaran

1.1.2.3 Metode pembelajaran

1.1.2.4 Media pembelajaran

1.1.2.5 Evaluasi pembelajaran

1.1.3 Lingkungan kelas, meliputi:

1.1.3.1 Kondisi fisik ruang kelas.

1.1.3.2 Situasi kelas selama guru menggunakan media audio visual.

1.1.3.3 Sarana dan prasarana di kelas.

1.1.3.4 Penataan posisi siswa di kelas.

1.1.4 Guru mata pelajaran, meliputi:

1.1.4.1 Kesiapan guru dalam mengajar

1.1.4.2 Variasi guru dalam mengajar

1.1.4.3 Cara guru dalam menggunakan media audio visual.

1.1.5 Siswa, meliputi:

1.1.5.1 Sikap siswa saat pembelajaran berlangsung 
1.1.5.2 Tanggapan/respon siswa saat guru menggunakan media audio visual dalam pembelajaran. 
Lampiran 4

\section{PEDOMAN WAWANCARA}

\section{PENGGUNAAN MEDIA AUDIO VISUAL DALAM PEMBELAJARAN SENI BUDAYA SUB MATERI MUSIK DI SMK NEGERI 03 SALATIGA}

\section{Oleh : Angga Dwi Winarno}

\section{Pedoman Wawancara dengan Guru}

1.1 Latar belakang pendidikan pengajar seni budaya

1.2 Waktu dan tempat yang dapat diadakan penelitian

1.3 Metode apa yang dipakai dalam pembelajaran seni budaya menggunakan media audio visual

1.4 Kurikulum apa yang dipakai dalam pembelajaran

1.5 Antusias siswa dalam pembelajaran seni budaya menggunakan media audio visual

1.6 Perbedaan menggunakan dan tidak menggunakan media audio visual saat pembelajaran seni budaya

1.7 Kendala dalam pembelajaran seni budaya menggunakan media audio visual

1.8 Kelebihan dan kekurangan menggunakan media audio visual saat pembelajaran seni budaya

1.9 Apresiasi siswa dalam pembelajaran seni budaya menggunakan media audio visual

1.10Target yang harus dicapai dalam setiap pertemuan

\section{Pedoman Wawancara dengan siswa}

2.1 Materi yang telah disampaikan pengajar saat pembelajaran

2.2 Pemahanan tentang materi yang disampaikan oleh pengajar

2.3 Pendapat tentang pembelajaran seni budaya menggunakan media audio visual

2.4 Kesulitan yang dihadapi dalam pembelajaran seni budaya

2.5 Kelebihan penggunaan media audio visual dalam penerapan pembelajaran seni budaya 
Lampiran 5

\section{PEDOMAN DOKUMENTASI}

PENGGUNAAN MEDIA AUDIO VISUAL DALAM PEMBELAJARAN SENI BUDAYA SUB MATERI MUSIK DI SMK NEGERI O3 SALATIGA

\section{Oleh : Angga Dwi Winarno}

\section{Pedoman Dokumentasi}

1.1 Gambaran umum lokasi penelitian

1.2 Sejarah SMK Negeri 03 Salatiga

1.3 Lokasi, letak dan kondisi lingkungan

1.4 Bentuk denah SMK Negeri 03 Salatiga

1.5 Letak dan kondisi bangunan tempat penelitian

1.6 Fasilitas, sarana dan prasarana

1.7 Profil pengajar seni budaya di SMK Negeri 03 Salatiga

1.8 Data siswa

1.9 Foto kegiatan belajar megajar 
Lampiran 6

PROGRAM TAHUNAN

MATA PELAJARAN

: Seni Budaya

SATUAN PENDIDIKAN

: SMK

KELAS

: X

TAHUN PELAJARAN

: 2016 / 2017

\begin{tabular}{|c|c|c|c|c|}
\hline \multirow[t]{2}{*}{ SEM. } & \multirow{2}{*}{$\begin{array}{l}\text { KOMPETENSI INTI } \\
\text { KOMPETENSI DASAR }\end{array}$} & \multicolumn{2}{|c|}{$\begin{array}{l}\text { JUMLAH JAM } \\
\text { PELAJARAN }\end{array}$} & \multirow[t]{2}{*}{ KET. } \\
\hline & & TM & PS & \\
\hline I & $\begin{array}{l}\text { KI 1:Menghayati dan mengamalkan ajaran agama yang } \\
\text { dianutnya } \\
\text { KI 2:Menghayati dan mengamalkan perilaku jujur, } \\
\text { disiplin, tanggung jawab, peduli, (gotong royong, } \\
\text { kerjasama, toleran, damai), santun, responsif dan } \\
\text { proaktif, dan menunjukkan sikap sebagai bagian dari } \\
\text { solusi atas berbagai permasalahan dalam berinteraksi } \\
\text { secara efektif dengan lingkungan sosial dan alam serta } \\
\text { dalam menempatkan diri sebagai cerminan bangsa } \\
\text { dalam pergaulan dunia } \\
\text { KI 3:Memahami, menerapkan, menganalisis } \\
\text { pengetahuan faktual, } \\
\text { berdasarkan rasa keingintahuannya tentang ilmu } \\
\text { pengetahuan, teknologi, seni, budaya, dan humaniora }\end{array}$ & & & \\
\hline
\end{tabular}




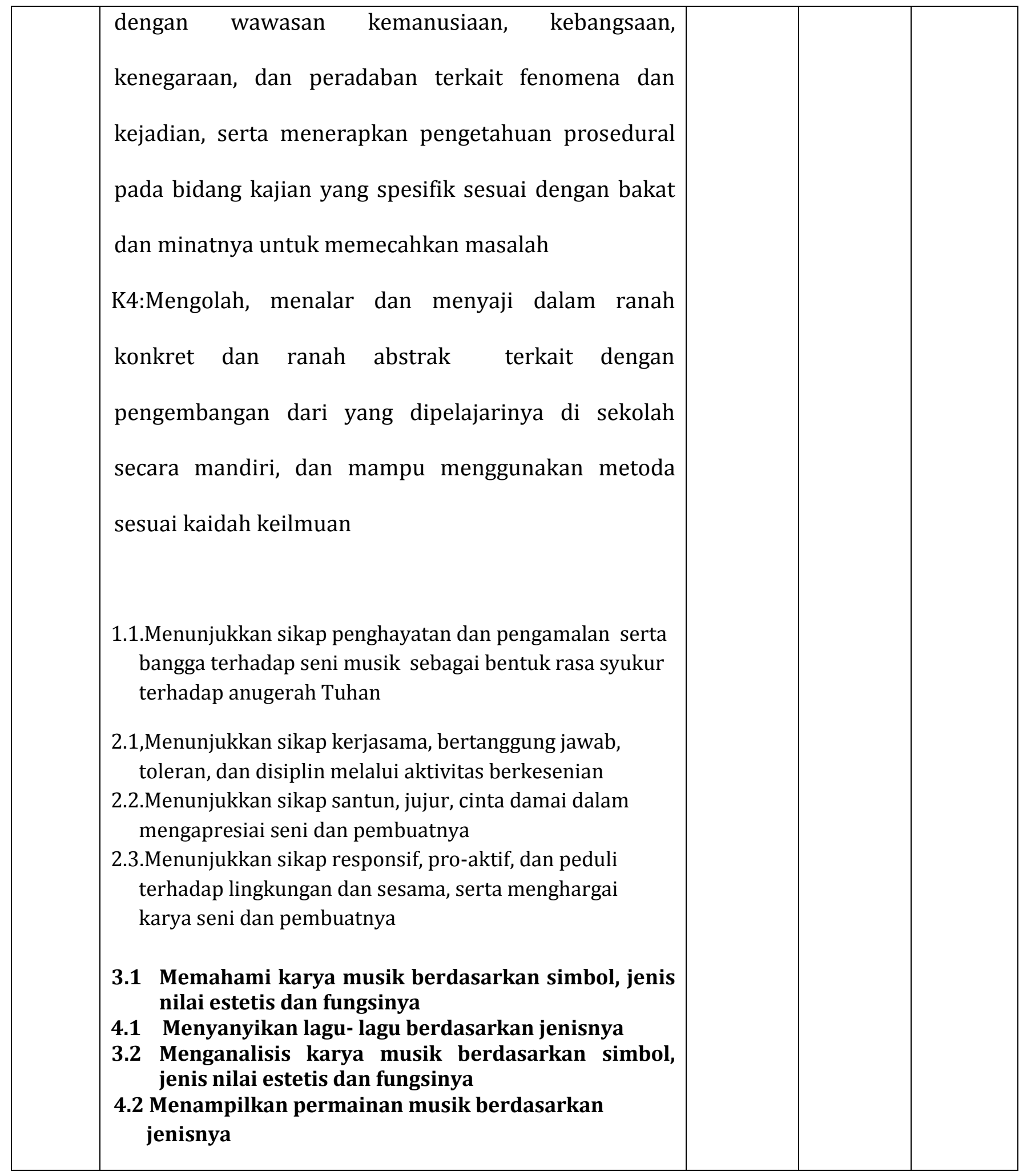




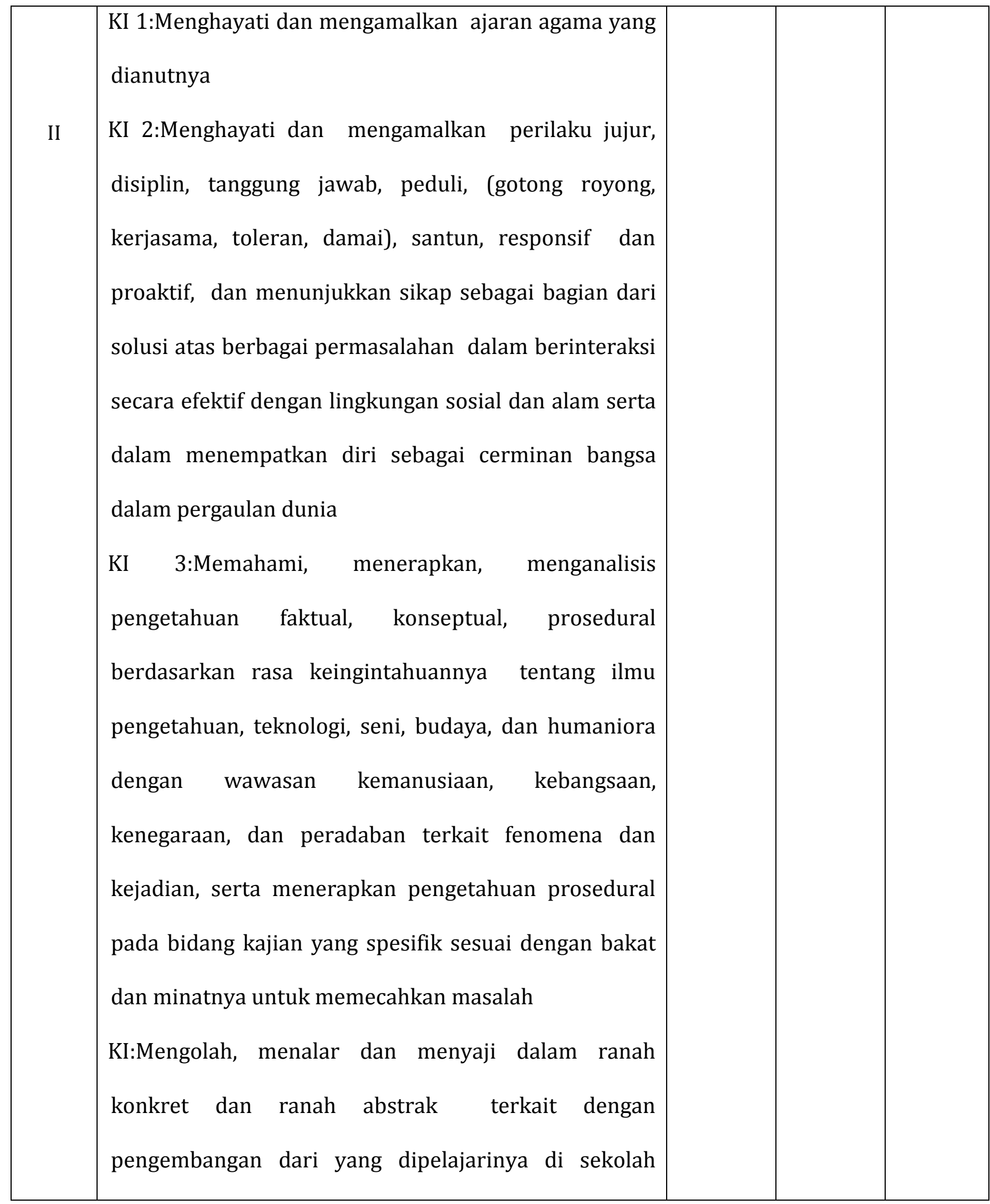


secara mandiri, dan mampu menggunakan metoda sesuai kaidah keilmuan

1.1.Menunjukkan sikap penghayatan dan pengamalan serta bangga terhadap seni musik sebagai bentuk rasa syukur terhadap anugerah Tuhan

2.1.Menunjukkan sikap kerjasama, bertanggung jawab, toleran, dan disiplin melalui aktivitas berkesenian

2..2.Menunjukkan sikap santun, jujur, cinta damai dalam mengapresiai seni dan pembuatnya

2.3.Menunjukkan sikap responsif, pro-aktif, dan peduli terhadap lingkungan dan sesama, serta menghargai karya seni dan pembuatnya

\subsection{Memahami rancangan pergelaran musik}

4.3. Mempergelarkan musik dengan memperhatikan nilai-nilai estetis

3.4 Menganalisis karya-karya musik dan kegiatan pergelaran musik

4.4 Membuat tulisan tentang beragam musik dan lagulagunya

Salatiga,1 Juli 2016

Waka Opendikur

Guru Mata Pelajaran

Indaryanto, S.Pd.T

Sulistiyo, S.Pd

NIP. 197906182009021002

NIP. 198005312009021001

Mengetahui

Kepala SMK N 3 Salatiga

Suripan, S.Pd

NIP. 196501201990031003 
Lampiran 7

\section{PROGRAM SEMESTER}

MATA PELAJARAN

SATUAN PENDIDIKAN

KELAS

SEMESTER

TAHUN PELAJARAN
: SENI BUDAYA (SENI MUSIK)

: SMK

: X

: GENAP

: $2016 / 2017$

\begin{tabular}{|c|c|c|c|c|}
\hline \multirow[t]{2}{*}{ SEM. } & \multirow{2}{*}{$\begin{array}{l}* \quad \text { KOMPETENSI INTI } \\
\text { KOMPETENSI DASAR }\end{array}$} & \multicolumn{2}{|c|}{$\begin{array}{l}\text { JUMLAH JAM } \\
\text { PELAJARAN }\end{array}$} & \multirow[t]{2}{*}{ KET. } \\
\hline & & TM & PS & \\
\hline II & $\begin{array}{l}\text { KI 1:Menghayati dan mengamalkan ajaran agama yang } \\
\text { dianutnya } \\
\text { KI 2:Menghayati dan mengamalkan perilaku jujur, disiplin, } \\
\text { tanggung jawab, peduli, (gotong royong, kerjasama, toleran, } \\
\text { damai), santun, responsif dan proaktif, dan menunjukkan sikap } \\
\text { sebagai bagian dari solusi atas berbagai permasalahan dalam } \\
\text { berinteraksi secara efektif dengan lingkungan sosial dan alam } \\
\text { serta dalam menempatkan diri sebagai cerminan bangsa dalam } \\
\text { pergaulan dunia } \\
\text { KI 3:Memahami, menerapkan, menganalisis pengetahuan } \\
\text { faktual, konseptual, prosedural berdasarkan rasa } \\
\text { keingintahuannya tentang ilmu pengetahuan, teknologi, seni, } \\
\text { budaya, dan humaniora dengan wawasan kemanusiaan, } \\
\text { kebangsaan, kenegaraan, dan peradaban terkait fenomena dan } \\
\text { kejadian, serta menerapkan pengetahuan prosedural pada }\end{array}$ & & & \\
\hline
\end{tabular}




\begin{tabular}{|c|}
\hline $\begin{array}{l}\text { bidang kajian yang spesifik sesuai dengan bakat dan minatnya } \\
\text { untuk memecahkan masalah } \\
\text { KI:Mengolah, menalar dan menyaji dalam ranah konkret dan } \\
\text { ranah abstrak terkait dengan pengembangan dari yang } \\
\text { dipelajarinya di sekolah secara mandiri, dan mampu } \\
\text { menggunakan metoda sesuai kaidah keilmuan } \\
\text { 1.1.Menunjukkan sikap penghayatan dan pengamalan serta } \\
\text { bangga terhadap seni musik sebagai bentuk rasa syukur } \\
\text { terhadap anugerah Tuhan } \\
\text { 2.1.Menunjukkan sikap kerjasama, bertanggung jawab, toleran, } \\
\text { dan disiplin melalui aktivitas berkesenian } \\
\text { 2.2.Menunjukkan sikap santun, jujur, cinta damai dalam } \\
\text { mengapresiai seni dan pembuatnya } \\
\text { 2.3.Menunjukkan sikap responsif, pro-aktif, dan peduli } \\
\text { terhadap lingkungan dan sesama, serta menghargai karya } \\
\text { seni dan pembuatnya } \\
\text { 3.3.Memahami rancangan pergelaran musik } \\
\text { 4.3. Mempergelarkan musik dengan memperhatikan } \\
\text { nilai-nilai estetis } \\
\text { 3.4 Menganalisis karya-karya musik dan kegiatan } \\
\text { pergelaran musik } \\
\text { 4.4 Membuat tulisan tentang beragam musik dan lagu- } \\
\text { lagunya }\end{array}$ \\
\hline
\end{tabular}

Salatiga, 9 Januari 2017

Waka Opendikur

Indaryanto, S.Pd.T

NIP. 197906182009021002
Guru Mata Pelajaran

Sulistiyo, S.Pd

NIP. 198005312009021001

Mengetahui

Kepala SMK N 3 Salatiga

Suripan, S.Pd

NIP. 196501201990031003 
Lampiran 8

\section{SILABUS SMK NEGERI 3 SALATIGA}

\section{MATA PELAJARAN}

\section{KELAS}

Kompetensi Inti

Kompetensi Inti 1

Kompetensi Inti 2

Kompetensi Inti 3

Kompetensi Inti 4

\section{SENI BUDAYA(SENI MUSIK)}

: X

Menghayati dan mengamalkan ajaran agama yang dianutnya

Menghayati dan mengamalkan perilaku jujur, disiplin, tanggung jawab, peduli, (gotong royong, kerjasama, toleran, damai), santun, responsif dan proaktif, dan menunjukkan sikap sebagai bagian dari solusi atas berbagai permasalahan dalam berinteraksi secara efektif dengan lingkungan sosial dan alam serta dalam menempatkan diri sebagai cerminan bangsa dalam pergaulan dunia

: Memahami, menerapkan, menganalisis pengetahuan faktual, konseptual, prosedural berdasarkan rasa keingintahuannya tentang ilmu pengetahuan, teknologi, seni, budaya, dan humaniora dengan wawasan kemanusiaan, kebangsaan, kenegaraan, dan peradaban terkait fenomena dan kejadian, serta menerapkan pengetahuan prosedural pada bidang kajian yang spesifik sesuai dengan bakat dan minatnya untuk memecahkan masalah

Mengolah, menalar dan menyaji dalam ranah konkret dan ranah abstrak terkait dengan pengembangan dari yang dipelajarinya di sekolah secara mandiri, dan mampu menggunakan metoda sesuai kaidah keilmuan 


\begin{tabular}{|c|c|c|c|c|c|}
\hline Kompetensi Dasar & Materi Pokok & Pembelajaran & Penilaian & Alokasi Waktu & Sumber Belajar \\
\hline $\begin{array}{l}\text { 1.1.Menunjukkan sikap penghayatan dan } \\
\text { pengamalan serta bangga terhadap seni } \\
\text { musik sebagai bentuk rasa syukur } \\
\text { terhadap anugerah Tuhan } \\
\text { 2.1 Menunjukkan sikap kerjasama, } \\
\text { bertanggung jawab, toleran, dan disiplin } \\
\text { melalui aktivitas berkesenian } \\
\text { 2.2 Menunjukkan sikap santun, jujur, cinta } \\
\text { damai dalam mengapresiai seni dan } \\
\text { pembuatnya } \\
\text { 2.3 Menunjukkan sikap responsif, pro-aktif, } \\
\text { dan peduli terhadap lingkungan dan } \\
\text { sesama, serta menghargai karya seni } \\
\text { dan pembuatnya } \\
\text { 3.3 Memahami karya musik } \\
\text { berdasarkan simbol, jenis nilai } \\
\text { estetis dan fungsinya } \\
\text { 4.2 Menyanyikan lagu- lagu } \\
\text { berdasarkan jenisnya }\end{array}$ & $\begin{array}{l}\text { Penyajian karya } \\
\text { musik }\end{array}$ & $\begin{array}{l}\text { Mengamati } \\
\text { - Membaca dan mendengarkan informasi } \\
\text { dan data tentang jenis, konsep, teknik } \\
\text { penyajian karya musik } \\
\text { Menanyakan } \\
\text { - Menanyakan tentang jenis, konsep, } \\
\text { teknik penyajian karya musik } \\
\text { Mengeksplorasi } \\
\text { - Mengumpulkan informasi dari berbagai } \\
\text { sumber belajar tentang tentang jenis, } \\
\text { konsep, teknik penyajian karya musik } \\
\text { - Mengidentifikasi perbedaan konsep, } \\
\text { teknik, dan prosedur penampilan musik } \\
\text { Mengasosiasi } \\
\text { - Menunjukkan bahwa konsep, teknik, dan } \\
\text { prosedur penampilan musik ada kemiripan } \\
\text { dengan bidang seni pertunjukan lainnya } \\
\text { - Membandingkan konsep, teknik, dan } \\
\text { prosedur dalam membuat karya musik } \\
\text { Mengomunikasi } \\
\text { - Menampilkan karya musik dengan } \\
\text { bernyanyi dan bermain musik } \\
\text { Membuat tulisan kritik musik topik } \\
\text { penyajian musik }\end{array}$ & $\begin{array}{l}\text { Unjuk Kerja } \\
\text { Penampilan karya } \\
\text { musik }\end{array}$ & $9 \mathrm{JP}$ & $\begin{array}{l}\text { Buku Seni Budaya } \\
\text { kelas X } \\
\text { VCD pertunjukan } \\
\text { music } \\
\text { Kumpulan lagu-lagu } \\
\text { daerah } \\
\text { Buku teknik bermain } \\
\text { alat musik } \\
\text { Ensiklopedi musik } \\
\text { Indonesia } \\
\text { Buku-buku yang } \\
\text { relevan }\end{array}$ \\
\hline
\end{tabular}




\begin{tabular}{|c|c|c|c|c|c|}
\hline Kompetensi Dasar & Materi Pokok & Pembelajaran & Penilaian & Alokasi Waktu & Sumber Belajar \\
\hline $\begin{array}{l}\text { 1.1.Menunjukkan sikap penghayatan dan } \\
\text { pengamalan serta bangga terhadap seni } \\
\text { musik sebagai bentuk rasa syukur } \\
\text { terhadap anugerah Tuhan } \\
\text { 2.4 Menunjukkan sikap kerjasama, } \\
\text { bertanggung jawab, toleran, dan disiplin } \\
\text { melalui aktivitas berkesenian } \\
\text { 2.5 Menunjukkan sikap santun, jujur, cinta } \\
\text { damai dalam mengapresiai seni dan } \\
\text { pembuatnya } \\
\text { 2.6 Menunjukkan sikap responsif, pro-aktif, } \\
\text { dan peduli terhadap lingkungan dan } \\
\text { sesama, serta menghargai karya seni } \\
\text { dan pembuatnya } \\
\text { 3.4 Menganalisis karya musik } \\
\text { berdasarkan simbol, jenis nilai } \\
\text { estetis dan fungsinya } \\
\text { 4.2 Menampilkan permainan musik } \\
\text { berdasarkan jenisnya }\end{array}$ & $\begin{array}{l}\text { Penampilan karya } \\
\text { buatan sendiri }\end{array}$ & $\begin{array}{l}\text { Mengamati } \\
\text { - Membaca dan mendengarkan } \\
\text { informasi tentang konsep, teknik, dan } \\
\text { prosedur dalam membuat karya musik } \\
\text { Menanyakan } \\
\text { - } \quad \text { Menanyakan konsep, teknik, dan } \\
\text { prosedur dalam membuat karya musik } \\
\text { Mengeksplorasi } \\
\text { - Mengumpulkan informasi dari } \\
\text { berbagai sumber belajar tentang } \\
\text { konsep, teknik, dan prosedur dalam } \\
\text { penyajian karya musik } \\
\text { - Mengidentifikasi perbedaan konsep, } \\
\text { teknik, dan prosedur penyajian karya } \\
\text { musik yang ada } \\
\text { - Membandingkan konsep, teknik, dan } \\
\text { prosedur dalam penyajian karya musik } \\
\text { Mengasosiasi } \\
\text { - Membandingkan konsep, teknik, dan } \\
\text { prosedur pada penyajian musik } \\
\text { dengan seni pertunjukan lainnya } \\
\text { Mengkomunikasi } \\
\text { - Menyanyikan lagu } \\
\text { - Mempergelarkan musik }\end{array}$ & $\begin{array}{l}\text { Unjuk Kerja } \\
\text { Menampilkan karya } \\
\text { musik buatan sendiri }\end{array}$ & $8 \mathrm{JP}$ & $\begin{array}{l}\text { Buku Seni Budaya } \\
\text { kelas X } \\
\text { VCD pertunjukan } \\
\text { music } \\
\text { Kumpulan lagu-lagu } \\
\text { daerah } \\
\text { Buku teknik bermain } \\
\text { alat musik } \\
\text { Ensiklopedi musik } \\
\text { Indonesia } \\
\text { Buku-buku yang } \\
\text { relevan }\end{array}$ \\
\hline
\end{tabular}




\begin{tabular}{|c|c|c|c|c|c|}
\hline Kompetensi Dasar & Materi Pokok & Pembelajaran & Penilaian & Alokasi Waktu & Sumber Belajar** \\
\hline $\begin{array}{l}\text { 1.1.Menunjukkan sikap penghayatan dan } \\
\text { pengamalan serta bangga terhadap seni } \\
\text { musik sebagai bentuk rasa syukur } \\
\text { terhadap anugerah Tuhan } \\
\text { 2.1.Menunjukkan sikap kerjasama, } \\
\text { bertanggung jawab, toleran, dan disiplin } \\
\text { melalui aktivitas berkesenian } \\
\text { 2.2.Menunjukkan sikap santun, jujur, cinta } \\
\text { damai dalam mengapresiai seni dan } \\
\text { pembuatnya } \\
\text { 2.3.Menunjukkan sikap responsif, pro-aktif, } \\
\text { dan peduli terhadap lingkungan dan } \\
\text { sesama, serta menghargai karya seni } \\
\text { dan pembuatnya } \\
\text { 3.3.Memahami rancangan pergelaran } \\
\text { musik } \\
\text { 4.3. Mempergelarkan musik dengan } \\
\text { memperhatikan nilai-nilai estetis }\end{array}$ & $\begin{array}{l}\text { Pergelaran musik } \\
\text { karya sendiri }\end{array}$ & $\begin{array}{l}\text { Mengamati } \\
\text { - Membaca dan mendengarkan } \\
\text { informasi tentang kepanitian, } \\
\text { undangan, persiapan pergelaran } \\
\text { musik } \\
\text { Menanyakan } \\
\text { - } \quad \text { Menanyakan konsep, teknik, dan } \\
\text { prosedur dalam pergelaran musik } \\
\text { Mengeksplorasi } \\
\text { - Mengumpulkan informasi dari } \\
\text { berbagai sumber belajar tentang } \\
\text { konsep, teknik, dan prosedur dalam } \\
\text { pergelarant karya musik } \\
\text { - Mengidentifikasi perbedaan konsep, } \\
\text { teknik, dan prosedur karya musik yang } \\
\text { ada } \\
\text { - Membandingkan konsep, teknik, dan } \\
\text { prosedur dalam pergelaran musik } \\
\text { Mengasosiasi } \\
\text { - Membandingkan konsep, teknik, dan } \\
\text { prosedur pada penyajian musik } \\
\text { dengan seni pertunjukan lainnya } \\
\text { Mengkomunikasi } \\
\text { - Menyanyikan lagu } \\
\text { - Mempergelarkan musik }\end{array}$ & $\begin{array}{l}\text { Unjuk Kerja } \\
\text { pergelaran musik karya } \\
\text { sendiri }\end{array}$ & $15 \mathrm{JP}$ & $\begin{array}{l}\text { Buku Seni Budaya } \\
\text { kelas X } \\
\text { VCD pertunjukan } \\
\text { music } \\
\text { Kumpulan lagu-lagu } \\
\text { daerah } \\
\text { Buku teknik bermain } \\
\text { alat musik } \\
\text { Ensiklopedi musik } \\
\text { Indonesia } \\
\text { Buku-buku yang } \\
\text { relevan }\end{array}$ \\
\hline
\end{tabular}




\begin{tabular}{|c|c|c|c|c|c|}
\hline $\begin{array}{l}\text { 1.1.Menunjukkan sikap penghayatan dan } \\
\text { pengamalan serta bangga terhadap seni } \\
\text { musik sebagai bentuk rasa syukur } \\
\text { terhadap anugerah Tuhan } \\
\text { 2.1.Menunjukkan sikap kerjasama, } \\
\text { bertanggung jawab, toleran, dan disiplin } \\
\text { melalui aktivitas berkesenian } \\
\text { 2.2.Menunjukkan sikap santun, jujur, cinta } \\
\text { damai dalam mengapresiai seni dan } \\
\text { pembuatnya } \\
\text { 2.3.Menunjukkan sikap responsif, pro-aktif, } \\
\text { dan peduli terhadap lingkungan dan } \\
\text { sesama, serta menghargai karya seni } \\
\text { dan pembuatnya } \\
\text { 3.4 Menganalisis karya-karya musik dan } \\
\text { kegiatan pergelaran musik } \\
\text { 4.5 Membuat tulisan tentang beragam } \\
\text { musik dan lagu-lagunya }\end{array}$ & Kritik Musik & $\begin{array}{l}\text { Mengamati } \\
\text { - Membaca dan mendengarkan } \\
\text { informasi tentang kepanitian, } \\
\text { undangan, persiapan pergelaran } \\
\text { musik } \\
\text { Menanyakan } \\
\text { - Menanyakan konsep, teknik, dan } \\
\text { prosedur dalam pergelaran musik } \\
\text { Mengeksplorasi } \\
\text { - Mengumpulkan informasi dari } \\
\text { berbagai sumber belajar tentang } \\
\text { konsep, teknik, dan prosedur dalam } \\
\text { pergelarant karya musik } \\
\text { - Mengidentifikasi perbedaan } \\
\text { konsep, teknik, dan prosedur karya } \\
\text { musik yang ada } \\
\text { - Membandingkan konsep, teknik, } \\
\text { dan prosedur dalam pergelaran } \\
\text { musik } \\
\text { Mengasosiasi } \\
\text { - Membandingkan konsep, teknik, } \\
\text { dan prosedur pada penyajian musik } \\
\text { dengan seni pertunjukan lainnya } \\
\text { Mengkomunikasi } \\
\text { - Membuat tulisan tentang kritik musik }\end{array}$ & $\begin{array}{l}\text { Produk } \\
\text { Tulisan tentang kritik } \\
\text { musik }\end{array}$ & $3 \mathrm{JP}$ & $\begin{array}{l}\text { Buku Seni Budaya } \\
\text { kelas X } \\
\text { VCD pertunjukan } \\
\text { music } \\
\text { Kumpulan lagu-lagu } \\
\text { daerah } \\
\text { Buku teknik bermain } \\
\text { alat musik } \\
\text { Ensiklopedi musik } \\
\text { Indonesia } \\
\text { Buku-buku yang } \\
\text { relevan }\end{array}$ \\
\hline
\end{tabular}


Lampiran 9

\section{RENCANA PELAKSANAAN PEMBELAJARAN}

Sekolah : SMK NEGERI 3 SALATIGA

Mata Pelajaran : SENI BUDAYA

Kelas/Semester : X/Genap

AlokasiWaktu $\quad: 17 \times 2$ Jam Pertemuan

A. Kompetensi Inti

KI 3. Memahami, menerapkan, dan menganalisis pengetahuan faktual, konseptual, dan prosedural berdasarkan rasa ingin tahunya tentang ilmu pengetahuan, teknologi, seni, budaya, dan humaniora dalam wawasan kemanusiaan, kebangsaan, kenegaraan, dan peradaban terkait penyebab fenomena dan kejadian dalam bidang kerja yang spesifik untukmemecahkan masalah.

KI 4. Mengolah, menalar, dan menyaji dalam ranah konkret dan ranah abstrak terkait dengan pengembangan dari yang dipelajarinya di sekolah secara mandiri, dan mampu melaksanakan tugas spesifik di bawah pengawasan langsung.

B. KompetensiDasar

3.3. Memahami rancangan pergelaran musik

4.3. Mempergelarkan musik dengan memperhatikan nilai-nilai estetis

C. IndikatorPencapaianKompetensi

1. Menggali informasi tentang rancangan pergelaran berdasarkan jenis dan fungsi

2. Memadukan rancangan pergelaran musik sesuai pilihan

3. Merancang karya untuk persiapan pergelaran musik dengan memperhatikan nilai-nilai estetis

4. Mendemonstrasikan pagelaran seni musik berdasarkan materi pilihan sendiri

D. TujuanPembelajaran

1. Setelah menggali informasi lewat tayangan video pementasan musik dan berdiskusi, peserta didik akan dapat informasi tentang pementasan dengan mandiri

2. Setelah menemukan informasi dan berdiskusi peserta didik akan dapat :

a. Menganalisis pementasan musik

b. Mengkorelasikan pementasan musik dengan seni yang lain(drama,tari) 
3. Disediakan waktu untuk berdiskusi dan mencari informasi tentang pementasan musik peserta didik dapat merancang pergelaran musik dengan mandiri

4. Disediakan tempat, waktu untuk digunakan mendemonstrasikan karya pergelaran musik berdasarkan pilihan sendiri dengan percaya diri

E. Materi Pembelajaran

1. Rancangan Pergelaran musik

2. Praktik pergelaran musik

F. Pendekatan, Model danMetode

1. Saintifik, Discovery Learning

2. Saintifik, PBL

G. Kegiatan Pembelajaran

1. Pertemuan Kesatu:*)

a. Pendahuluan/Kegiatan Awal (10 menit)

Pada kegiatan pendahuluan guru:

- Mengkondisikan suasana belajar yang menyenangkan.

- Menyampaikan kompetensi yang akan dicapai dan manfaatnya bagi kehidupan.

- Menyampaikan garis besar cakupan materi dan kegiatan yang akan dilakukan.

- Menyampaikan lingkup dan teknik penilaian yang akan digunakan.

b. KegiatanInti (105 menit) Pemberian stimulus terhadap siswa

- Guru meminta siswa untuk melihat pergelaran musik melalu ibahan tayangan video.

- Guru menugaskan siswa membaca buku untuk mengidentifikasi pergelaran musik.

- Siswa melihat bahan tayang yang disajikan oleh Guru.

- Siswa membaca buku berkaitan dengan pergelaran musik.

C. Penutup (10 menit)

Kegiatan penutup meliputi antara lain:

- Membuat rangkuman/simpulan pelajaran.

- Refleksi terhadap kegiatan yang sudah dilaksanakan.

- Merencanakan kegiatan tindak lanjut dalam bentuk tugas kelompok/ perseorangan (jika diperlukan).

- Menyampaikan rencana pembelajaran pada pertemuan berikutnya. 
2. PertemuanKedua:*)

a. Pendahuluan/Kegiatan Awal (10menit)

Pada kegiatan pendahuluan guru:

- Mengkondisikan suasana belajar yang menyenangkan.

- Mendiskusikan kompetensi yang telah dipelajari dan dikembangkan sebelumnya terkait dengan kompetensi yang akan dipelajari.

- Menyampaikan kompetensi yang akan dicapai dan manfaatnya bagi kehidupan.

- Menyampaikan garis besar cakupan materi dan kegiatan yang akan dilakukan.

- Menyampaikan lingkup dan teknik penilaian yang akan digunakan.

b. KegiatanInti (105menit) Identifikasi masalah

- Guru meminta siswa untuk mengidentifikasi rancangan pergelaran musik

- Siswa mendiskusikan dan mengidentifikasi tentang rancangan pergelaran musik

c. Penutup (10 menit),

Kegiatan penutup meliputi antara lain:

- Membuat rangkuman/simpulan pelajaran.

- Refleksi terhadap kegiatan yang sudah dilaksanakan.

- Merencanakan kegiatan tindak lanjut dalam bentuk tugas kelompok/ perseorangan (jika diperlukan).

- menyampaikanrencanapembelajaranpadapertemuanberikutnya.

3. Pertemuan ketiga

a. Pendahuluan/Kegiatan Awal (10menit)

Pada kegiatan pendahuluan guru:

- Mengkondisikan suasana belajar yang menyenangkan.

- Mendiskusikan kompetensi yang telah dipelajari dan dikembangkan sebelumnya terkait dengan kompetensi yang akan dipelajari.

- Menyampaikan kompetensi yang akan dicapai dan manfaatnya bagi kehidupan.

- Menyampaikan garis besar cakupan materi dan kegiatan yang akan dilakukan.

- Menyampaikan lingkup dan teknik penilaian yang akan digunakan.

b. Kegiatan Inti (105 menit)

Pengumpulan data

- Guru menugaskan mengumpulkan data informasi tentang 
rancangan pergelaran musik

- Siswa mengumpulkan data informasi tentang pergelaran musik

c. Penutup(10 Menit)

Kegiatan penutup meliputi antara lain:

- Membuat rangkuman/simpulan pelajaran.

- Refleksi terhadap kegiatan yang sudah dilaksanakan.

- Merencanakan kegiatan tindak lanjut dalam bentuk tugas kelompok/ perseorangan (jika diperlukan).

- Menyampaikan rencana pembelajaran pada pertemuan berikutnya.

4. Pertemuan Keempat

a. Pendahuluan/Kegiatan Awal (10menit)

Pada kegiatan pendahuluan guru:

- Mengkondisikan suasana belajar yang menyenangkan.

- Mendiskusikan kompetensi yang telah dipelajari dan dikembangkan sebelumnya terkait dengan kompetensi yang akan dipelajari.

- Menyampaikan kompetensi yang akan dicapai dan manfaatnya bagi kehidupan.

- Menyampaikan garis besar cakupan materi dan kegiatan yang akan dilakukan.

- Menyampaikan lingkup dan teknik penilaian yang akan digunakan.

b. Kegiatan Inti (105 menit)

Pembuktian

- Guru menugaskan siswa merancang penampilan musik untuk pergelaran musik

- Siswa merancang penampilan musik untuk pergelaran musik

C. Penutup(10 Menit)

Kegiatan penutup meliputi antara lain:

- Membuat rangkuman/simpulan pelajaran.

- Refleksi terhadap kegiatan yang sudah dilaksanakan.

- Merencanakan kegiatan tindak lanjut dalam bentuk tugas kelompok/ perseorangan (jika diperlukan).

- Menyampaikan rencana pembelajaran pada pertemuan berikutnya.

5. Pertemuan kelima

a. Pendahuluan/Kegiatan Awal (10menit)

Pada kegiatan pendahuluan guru: 
- Mengkondisikan suasana belajar yang menyenangkan.

- Mendiskusikan kompetensi yang telah dipelajari dan dikembangkan sebelumnya terkait dengan kompetensi yang akan dipelajari.

- Menyampaikan kompetensi yang akan dicapai dan manfaatnya bagi kehidupan.

- Menyampaikan garis besar cakupan materi dan kegiatan yang akan dilakukan.

- Menyampaikan lingkup dan teknik penilaian yang akan digunakan.

b. Kegiatan Inti (105 menit)

Pembuktian

- Guru menugaskan siswa untuk latihan pertama sesuai dengan materi penampilan seni kreasi sesuai dengan pilihannya sendiri/kelompok

- Siswa latihan sesuai dengan materi penampilan seni kreasi sesuai dengan pilihannya sendiri/kelompok

c. Penutup(10 Menit)

Kegiatan penutup meliputi antara lain:

Kegiatan penutup meliputi antara lain:

- Membuat rangkuman/simpulan dari hasil latihan pertama

- Refleksi terhadap kegiatan yang sudah dilaksanakan.

- Merencanakan kegiatan tindak lanjut dalam bentuk tugas kelompok/ perseorangan (jika diperlukan).

- Menyampaikan rencana pembelajaran pada pertemuan berikutnya.

6. Pertemuan keenam

a. Pendahuluan/Kegiatan Awal (10menit)

Pada kegiatan pendahuluan guru:

- Mengkondisikan suasana belajar yang menyenangkan.

- Mendiskusikan kompetensi yang telah dipelajari dan dikembangkan sebelumnya terkait dengan kompetensi yang akan dipelajari.

- Menyampaikan kompetensi yang akan dicapai dan manfaatnya bagi kehidupan.

- Menyampaikan garis besar cakupan materi dan kegiatan yang akan dilakukan.

- Menyampaikan lingkup dan teknik penilaian yang akan digunakan.

b. Kegiatan Inti (105 menit)

Pembuktian 
- Guru menugaskan siswa untuk latihan kedua sesuai dengan materi penampilan seni kreasi sesuai dengan pilihannya sendiri/kelompok

- Siswa latihan sesuai dengan materi penampilan seni kreasi sesuai dengan pilihannya sendiri/kelompok

c. Penutup(10 Menit)

Kegiatan penutup meliputi antara lain:

Kegiatan penutup meliputi antara lain:

- Membuat rangkuman/simpulan latihan kedua

- Refleksi terhadap kegiatan yang sudah dilaksanakan.

- Merencan akan kegiatan tindak lanjut dalam bentuk tugas kelompok/ perseorangan (jika diperlukan).

- Menyampaikan rencana pembelajaran pada pertemuan berikutnya.

7. Pertemuan Ketujuh

a. Pendahuluan/Kegiatan Awal (10menit)

Pada kegiatan pendahuluan guru:

- Mengkondisikan suasana belajar yang menyenangkan.

- Mendiskusikan kompetensi yang telah dipelajari dan dikembangkan sebelumnya terkait dengan kompetensi yang akan dipelajari.

- Menyampaikan kompetensi yang akan dicapai dan manfaatnya bagi kehidupan.

- Menyampaikan garis besar cakupan materi dan kegiatan yang akan dilakukan.

- Menyampaikan lingkup dan teknik penilaian yang akan digunakan.

\section{b. Kegiatan Inti (105 menit)}

Pembuktian

- Guru menugaskan siswa untuk latihan ketigasesuai dengan materi penampilan seni kreasi sesuai dengan pilihannya sendiri/kelompok

- Siswa latihan sesuai dengan materi penampilan seni kreasi sesuai dengan pilihannya sendiri/kelompok

c. Penutup(10 Menit)

Kegiatan penutup meliputi antara lain:

Kegiatan penutup meliputi antara lain:

- Membuat rangkuman/simpulan latihan ketiga

- Refleksi terhadap kegiatan yang sudah dilaksanakan.

- Merencanakan kegiatan tindak lanjut dalam bentuk tugas kelompok/ perseorangan (jika diperlukan). 
8. Pertemuan kedelapan

a. Pendahuluan/Kegiatan Awal (10menit)

Pada kegiatan pendahuluan guru:

- Mengkondisikan suasana belajar yang menyenangkan.

- Mendiskusikan kompetensi yang telah dipelajari dan dikembangkan sebelumnya terkait dengan kompetensi yang akan dipelajari.

- Menyampaikan kompetensi yang akan dicapai dan manfaatnya bagi kehidupan.

- Menyampaikan garis besar cakupan materi dan kegiatan yang akan dilakukan.

- Menyampaikan lingkup dan teknik penilaian yang akan digunakan.

b. Kegiatan Inti (105 menit)

Pembuktian

- Guru menugaskan siswa untuk latihan keempat sesuai dengan materi penampilan seni kreasi sesuai dengan pilihannya sendiri/kelompok

- Siswa latihan sesuai dengan materi penampilan seni kreasi sesuai dengan pilihannya sendiri/kelompok

c. Penutup(10 Menit)

Kegiatan penutup meliputi antara lain:

- Membuat rangkuman/simpulan latihan keempat

- Refleksi terhadap kegiatan yang sudah dilaksanakan.

- Merencanakan kegiatan tindak lanjut dalam bentuk tugas kelompok/ perseorangan (jika diperlukan).

9. Pertemuan Kesembilan

a. Pendahuluan/Kegiatan Awal (10menit)

Pada kegiatan pendahuluan guru:

- Mengkondisikan suasana belajar yang menyenangkan.

- Mendiskusikan kompetensi yang telah dipelajari dan dikembangkan sebelumnya terkait dengan kompetensi yang akan dipelajari.

- Menyampaikan kompetensi yang akan dicapai dan manfaatnya bagi kehidupan.

- Menyampaikan garis besar cakupan materi dan kegiatan yang akan dilakukan.

- Menyampaikan lingkup dan teknik penilaian yang akan digunakan. 


\section{b. Kegiatan Inti (105 menit)}

Pembuktian

- Guru menugaskan siswa untuk latihan kelima sesuai dengan materi penampilan seni kreasi sesuai dengan pilihannya sendiri/kelompok

- Siswa latihan sesuai dengan materi penampilan seni kreasi sesuai dengan pilihannya sendiri/kelompok

c. Penutup(10 Menit)

Kegiatan penutup meliputi antara lain:

- Membuat rangkuman/simpulan latihan kelima

- Refleksi terhadap kegiatan yang sudah dilaksanakan.

- Merencanakan kegiatan tindak lanjut dalam bentuk tugas kelompok/ perseorangan (jika diperlukan).

10. Pertemuan Kesepuluh

a. Pendahuluan/Kegiatan Awal (10menit)

Pada kegiatan pendahuluan guru:

- Mengkondisikan suasana belajar yang menyenangkan.

- Mendiskusikan kompetensi yang telah dipelajari dan dikembangkan sebelumnya terkait dengan kompetensi yang akan dipelajari.

- Menyampaikan kompetensi yang akan dicapai dan manfaatnya bagi kehidupan.

- Menyampaikan garis besar cakupan materi dan kegiatan yang akan dilakukan.

- Menyampaikan lingkup dan teknik penilaian yang akan digunakan.

b. Kegiatan Inti (105 menit)

Pembuktian

- Guru menugaskan siswa untuk latihan keenam sesuai dengan materi penampilan seni kreasi sesuai dengan pilihannya sendiri/kelompok

- Siswa latihan sesuai dengan materi penampilan seni kreasi sesuai dengan pilihannya sendiri/kelompok

c. Penutup(10 Menit)

Kegiatanpenutupmeliputiantara lain:

- Membuat rangkuman/simpulan latihan keenam

- Refleksi terhadap kegiatan yang sudah dilaksanakan.

- Merencanakan kegiatan tindak lanjut dalam bentuk tugas kelompok/ perseorangan (jika diperlukan). 
11. Pertemuan Kesebelas

a. Pendahuluan/Kegiatan Awal (10menit)

Pada kegiatan pendahuluan guru:

- Mengkondisikan suasana belajar yang menyenangkan.

- Mendiskusikan kompetensi yang telah dipelajari dan dikembangkan sebelumnya terkait dengan kompetensi yang akan dipelajari.

- Menyampaikan kompetensi yang akan dicapai dan manfaatnya bagi kehidupan.

- Menyampaikan garis besar cakupan materi dan kegiatan yang akan dilakukan.

- Menyampaikan lingkup dan teknik penilaian yang akan digunakan.

b. Kegiatan Inti (105 menit)

Pembuktian

- Guru menugaskan siswa untuk latihan ketujuh sesuai dengan materi penampilan seni kreasi sesuai dengan pilihannya sendiri/kelompok

- Siswa latihan sesuai dengan materi penampilan seni kreasi sesuai dengan pilihannya sendiri/kelompok

c. Penutup(10 Menit)

Kegiatanpenutupmeliputiantara lain:

- membuatrangkuman/simpulan latihan ketujuh

- refleksiterhadap kegiatan yang sudah dilaksanakan.

- Merencanakan kegiatan tindak lanjut dalam bentuk tugas kelompok/ perseorangan (jika diperlukan).

12. Pertemuan Keduabelas

a. Pendahuluan/Kegiatan Awal (10menit)

Pada kegiatan pendahuluan guru:

- Mengkondisikan suasana belajar yang menyenangkan.

- Mendiskusikan kompetensi yang telahdi pelajari dan dikembangkan sebelumnya terkait dengan kompetensi yang akan dipelajari.

- Menyampaikan kompetensi yang akan dicapai dan manfaatnya bagi kehidupan.

- Menyampaikan garis besar cakupan materi dan kegiatan yang akan dilakukan.

- Menyampaikan lingkup dan teknik penilaian yang akan digunakan.

b. Kegiatan Inti (105 menit) 


\section{Pembuktian}

- Guru menugaskan siswa untuk latihan ketujuh sesuai dengan materi penampilan seni kreasi sesuai dengan pilihannya sendiri/kelompok

- Siswa latihan sesuai dengan materi penampilan seni kreasi sesuai dengan pilihannya sendiri/kelompok

c. Penutup(10 Menit)

Kegiatanpenutupmeliputiantara lain:

- Membuat rangkuman/simpulan latihan kedelapan

- Refleksi terhadap kegiatan yang sudah dilaksanakan.

- Merencanakan kegiatan tindak lanjut dalam bentuk tugas kelompok/ perseorangan (jika diperlukan).

13. Pertemuan Ketigabelas

a. Pendahuluan/KegiatanAwal (10menit)

Pada kegiatanpendahuluan guru:

- Mengkondisikan suasana belajar yang menyenangkan.

- Mendiskusikan kompetensi yang telah dipelajari dan dikembangkan sebelumnya terkait dengan kompetensi yang akan dipelajari.

- Menyampaikan kompetensi yang akan dicapai dan manfaatnya bagi kehidupan.

- Menyampaikan garis besar cakupan materi dan kegiatan yang akan dilakukan.

- Menyampaikan lingkup dan teknik penilaian yang akan digunakan.

\section{b. Kegiatan Inti (105 menit)}

Pembuktian

- Guru menugaskan siswa untuk latihan ketujuh sesuai dengan materi penampilan seni kreasi sesuai dengan pilihannya sendiri/kelompok

- Siswa latihan sesuai dengan materi penampilan seni kreasi sesuai dengan pilihannya sendiri/kelompok

c. Penutup(10 Menit)

Kegiatan penutup meliputi antara lain:

- Membuat rangkuman/simpulan latihan kesembilan

- Refleksi terhadap kegiatan yang sudah dilaksanakan.

- Merencanakan kegiatan tindak lanjut dalam bentuk tugas kelompok/ perseorangan (jika diperlukan).

14. Pertemuan Keempat belas 

a. Pendahuluan/Kegiatan Awal (10menit)
Pada kegiatan pendahuluan guru:

- Mengkondisikan suasanabelajar yang menyenangkan.

- Mendiskusikan kompetensi yang telah dipelajari dan dikembangkan sebelumnya terkait dengan kompetensi yang akan dipelajari.

- Menyampaikan kompetensi yang akan dicapai dan manfaatnya bagi kehidupan.

- Menyampaikan garis besar cakupan materi dan kegiatan yang akan dilakukan.

- Menyampaikan lingkup dan teknik penilaian yang akan digunakan.

b. Kegiatan Inti (105 menit)

Pembuktian

- Guru menugaskan siswa untuk latihan ketujuh sesuai dengan materi penampilan seni kreasi sesuai dengan pilihannya sendiri/kelompok

- Siswa latihan sesuai dengan materi penampilan seni kreasi sesuai dengan pilihannya sendiri/kelompok

c. Penutup(10 Menit)

Kegiatanpenutupmeliputiantara lain:

- Membuat rangkuman/simpulan latihan kesepuluh

- Refleksi terhadap kegiatan yang sudah dilaksanakan.

- Merencanakan kegiatan tindak lanjut dalam bentuk tugas kelompok/ perseorangan (jika diperlukan).

15. Pertemuan Kelimabelas

a. Pendahuluan/Kegiatan Awal (10menit)

Pada kegiatan pendahuluan guru:

- Mengkondisikan suasana belajar yang menyenangkan.

- Mendiskusikan kompetensi yang telah dipelajari dan dikembangkan sebelumnya terkait dengan kompetensi yang akan dipelajari.

- Menyampaikan kompetensi yang akan dicapai dan manfaatnya bagi kehidupan.

- Menyampaikan garis besar cakupan materi dan kegiatan yang akan dilakukan.

- Menyampaikan lingkup dan teknik penilaian yang akan digunakan.

b. Kegiatan Inti (105 menit)

Pembuktian

- Guru menugaskan siswa untuk latihan ketujuh sesuai dengan materi 
penampilan seni kreasi sesuai dengan pilihannya sendiri/kelompok

- Siswa latihan sesuai dengan materi penampilan seni kreasi sesuai dengan pilihannya sendiri/kelompok

c. Penutup(10 Menit)

Kegiatanpenutupmeliputiantara lain:

- Membuat rangkuman/simpulan latihan kesebelas.

- Refleksi terhadap kegiatan yang sudah dilaksanakan.

- Merencanakan kegiatan tindak lanjut dalam bentuk tugas kelompok/ perseorangan (jika diperlukan).

16. Pertemuan keenambelas

a. Pendahuluan/Kegiatan Awal (10menit)

Pada kegiatan pendahuluan guru:

- Mengkondisikan suasana belajar yang menyenangkan.

- Menyampaikan garis besar cakupan materi dan kegiatan yang akan dilakukan.

- Menyampaikan lingkup dan teknik penilaian yang akan digunakan.

b. Kegiatan Inti (105 menit)

Menarik kesimpulan/generalisasi

- Guru menugaskan siswa untuk mempresentasikan hasil latihan penampilan seni kreasi sesuai dengan pilihannya sendiri/kelompok

- Siswa mempresentasikan hasil latihan penampilan seni kreasi sesuai dengan pilihannya sendiri/kelompok

- Siswa memberikan tanggapan

- Siswa menerima tanggapan dari siswa lain

- Siswa memperbaiki hasil presentasi

c. Penutup(10 Menit)

Kegiatan penutup meliputi antara lain:

- Membuat rangkuman/simpulan latihan kesebelas.

- Refleksi terhadap kegiatan yang sudah dilaksanakan.

- Merencanakan kegiatan tindak lanjut dalam bentuk tugas kelompok/ perseorangan (jika diperlukan).

menyampaikanrencanapembelajaranpadapertemuanberikutnya

D. PenilaianPembelajaran, Remedial danPengayaan

1. Instrumen dan teknik penilaian 


\begin{tabular}{||c|l|l|}
\hline \multicolumn{1}{|c|}{ KD } & TeknikPenilaian & \multicolumn{1}{c|}{ Instrumen } \\
\hline $\begin{array}{c}\text { 3.3. Memahami } \\
\text { rancangan } \\
\text { pergelaran } \\
\text { musik }\end{array}$ & 1. TesTertulis & $\begin{array}{l}\text { 1. Buatlah rancangan panitia } \\
\text { pergelaran musik kelas! } \\
\text { 2. Buatlah rancangan susunan materi } \\
\text { pergelaran musik dikelas! }\end{array}$ \\
\hline $\begin{array}{l}\text { 4.3Mempergelark } \\
\text { an musik dengan } \\
\text { memperhatikan } \\
\text { nilai-nilai estetis }\end{array}$ & $\begin{array}{c}\text { 1. Tespraktik/ } \\
\text { unjukkerja }\end{array}$ & $\begin{array}{l}\text { Demonstrasikan pergelaran } \\
\text { musik yang sudah } \\
\text { direncanakan! }\end{array}$ \\
\hline
\end{tabular}

2. Analisis Hasil Penilaian

KD 3.1

\section{Penskoran Jawaban dan Pengolahan Nilai}

1. Nilai 4 : jika sesuai kunci Jawabandana ada pengembangan jawaban

2. Nilai 3 : jika jawaban sesuai kunci jawaban

3. Nilai 2 : jika jawaban kurang sesuai dengan kunci jawaban

4. Nilai 1 : jika jawaban tidak sesuai dengan kunci jawaban

KD 4.7

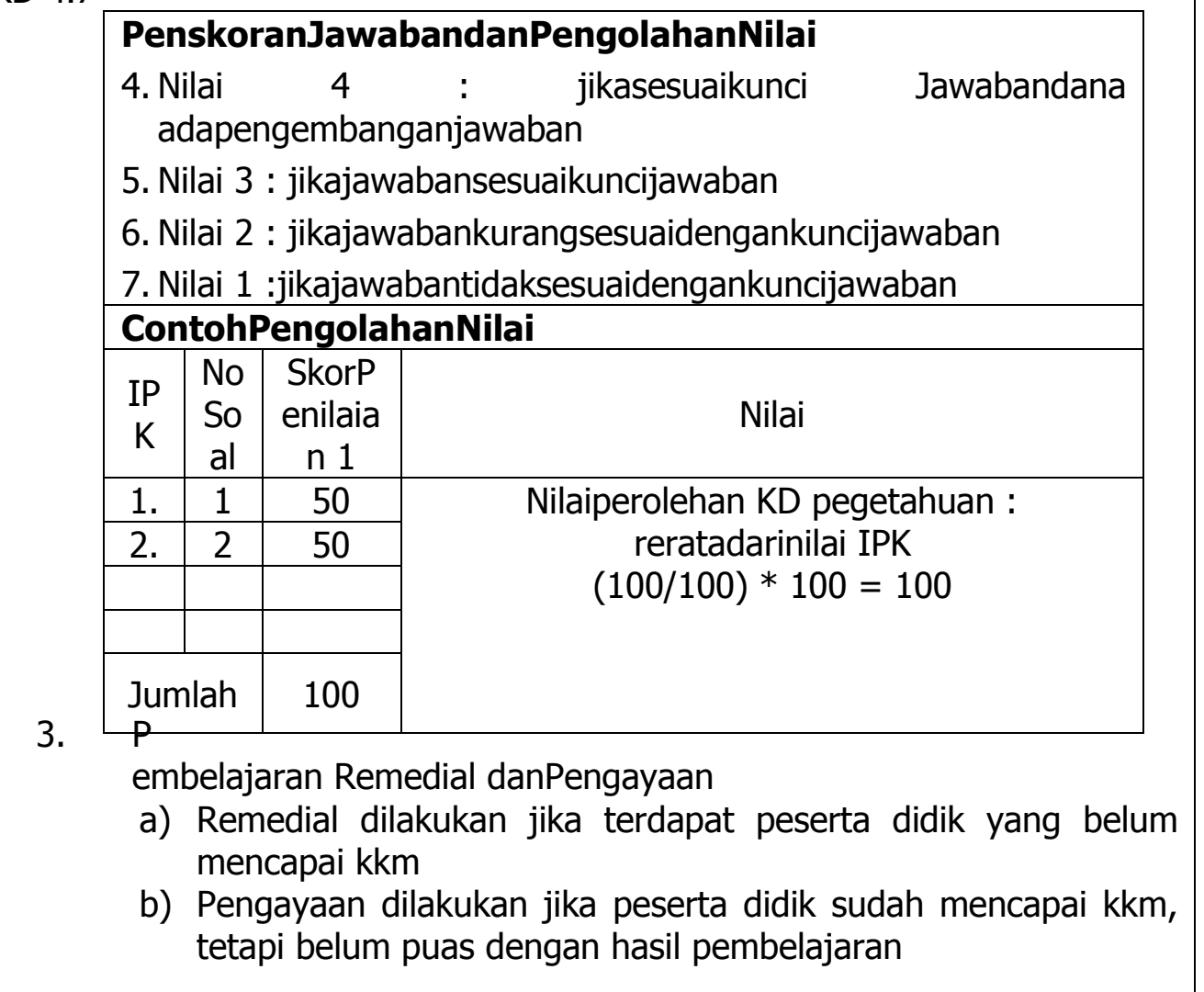


E. Media, Alat, Bahan, danSumberBelajar
1. Media
: video seni
2. Alat : laptop, Icd, sound system, alat musik
3. Bahan
:
4. SumberBelajar : Buku Seni Budaya kurikulum 2013 kelas X

Salatiga, 9 Januari 2017

Waka Opendikur Guru Mata Pelajaran

Indaryanto, S.Pd.T

Sulistiyo, S.Pd

NIP. 197906182009021002

NIP. 198005312009021001

Mengetahui

Kepala SMK N 3 Salatiga

Suripan, S.Pd

NIP. 196501201990031003 
Lampiran 10

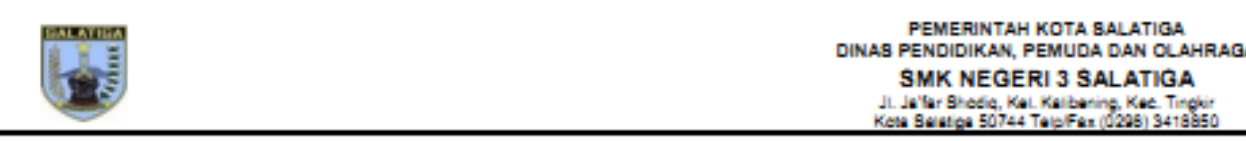

SMK NEGERI 3 SALATIGA

AKADEMIK TAHUN PELANARAN 2016/2017

KALENDER AKADEMIK TAHUN PELANAA
SMK NEGERI 3 SALATIGA

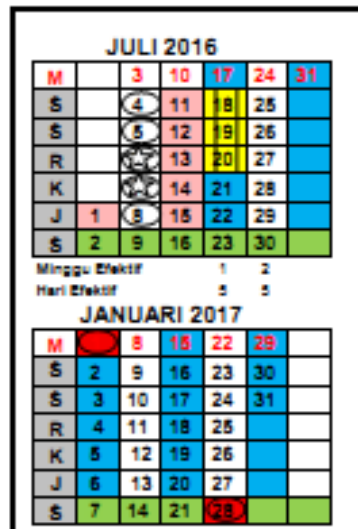

$\begin{array}{llll}1 & 2 & 3 & 4 \\ 1 & 2 & 3 & 4\end{array}$

$\begin{array}{lll}1 & 3 & 4 \\ 3 & 3 & 3 \\ 3 & 3 & 3\end{array}$

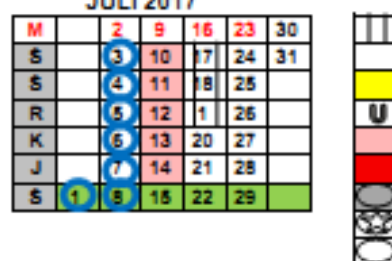

$\square_{\text {Biok } 1} \quad \square$ ilok

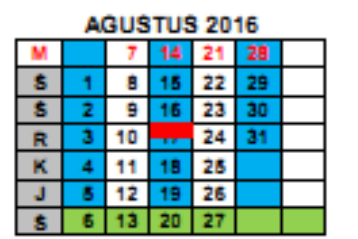

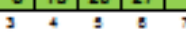

FEBRUARI 2017

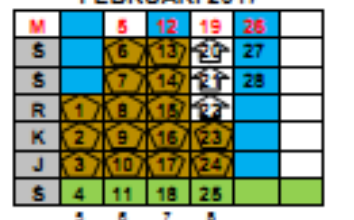

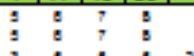

Awe Tahun Folizen 20162217

Kogitan Hri Balije Elatir

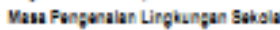

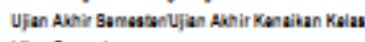

Lbur Benailar

tean Keagamaa

m ibul Adr

LBur Umเm ripaya but fox

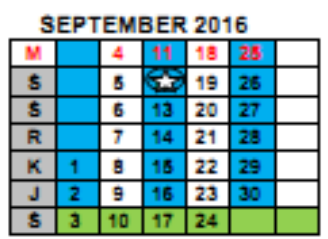

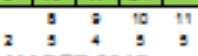

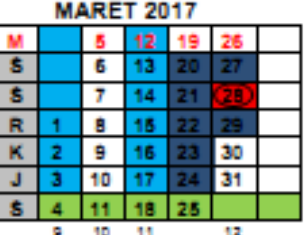

$\begin{array}{cccc}4 & 10 & 11 & 12 \\ 8 & 10 & 11 & 12 \\ 3 & 1 & 2 & 2\end{array}$

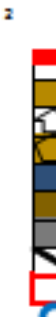

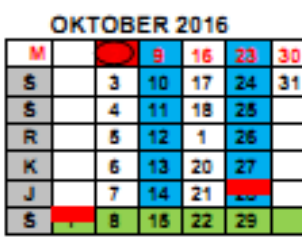
\begin{tabular}{l|l|l|l|l|}
\hline 8 & 18 & 22 & 29 & \\
\hline 12 & 13 & 14 & 19
\end{tabular}

APRII 2017

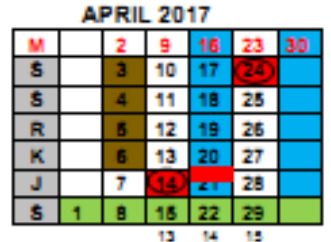

13 . 19

Mongikuti Upectere Hari Basar Natiand

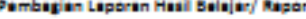

Derkirat fry out kots

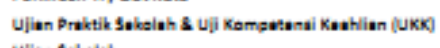

Ujien Sakolioh

Ujien Nuisent

Ujien Naisaral Sululaten

MUT GNan s solation

Derkiran ppos

NOVEMBER 2016

\begin{tabular}{|l|l|l|l|l|l|l|}
\hline$M$ & & 5 & 13 & 20 & 27 & \\
\hline 5 & & 7 & 14 & 21 & 25 & \\
\hline 5 & 1 & 8 & 15 & 22 & 29 & \\
\hline$R$ & 2 & 9 & 16 & 23 & 9 & \\
\hline$K$ & 3 & 1 & 17 & 24 & & \\
\hline$J$ & 4 & 11 & 18 & 25 & & \\
\hline 5 & 5 & 12 & 19 & 26 & & \\
\hline
\end{tabular}

DESEMBER 201

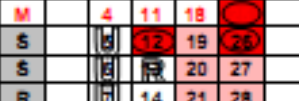

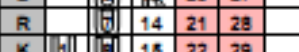

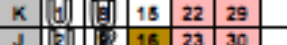
\begin{tabular}{l|l|l|l|l|l|l}
\hline & 5 & 12 & 19 & 26 & & \\
\hline
\end{tabular}

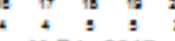

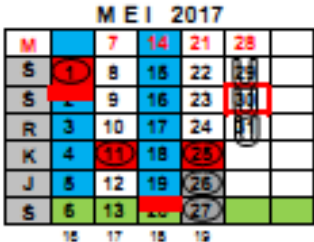

181718 \begin{tabular}{ll|l|l|l|l|l|l|}
\hline & 3 & 10 & 17 & 24 & 31 & \\
\hline
\end{tabular}

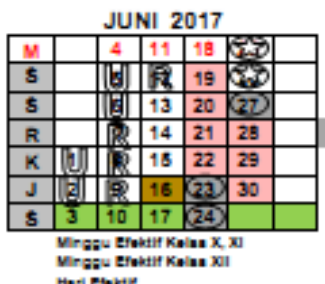

somateve : os arion

Somane 11

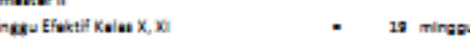
:

Rarigotifatuxil

\begin{tabular}{|c|c|c|c|c|c|c|c|}
\hline \multirow[t]{3}{*}{ 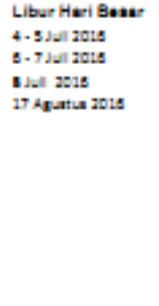 } & 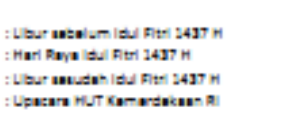 & 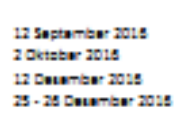 & 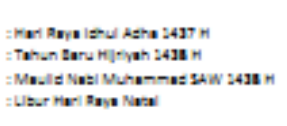 & 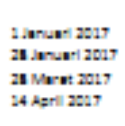 & 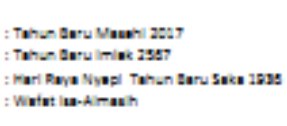 & 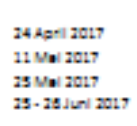 & 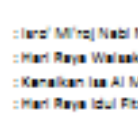 \\
\hline & & & & & & Sazatga, 1 & 12016 \\
\hline & Kapela saviden & & & & & waye & \\
\hline
\end{tabular}


Lampiran 11

\section{DATA SISWA SMK NEGERI 03 SALATIGA}

\section{TAHUN 2016/2017}

Kelas : X Ototronika 1

Wali Kelas : Dimas Nico Saputra, S.Pd

\begin{tabular}{|c|c|c|c|c|c|}
\hline NO & NISN & NAMA & $\mathrm{L} / \mathrm{P}$ & TEMPAT LAHIR & TGL. LAHIR \\
\hline & 932618 & ARIS FAJAR WAHAB & $\mathrm{L}$ & Salatiga & 13-06-1999 \\
\hline & 932548 & DANANG DANU RIFAI & $\mathrm{L}$ & Salatiga & 05-08-1999 \\
\hline & 932555 & FAJAR RAMADHAN & $\mathrm{L}$ & Salatiga & $13-12-2000$ \\
\hline & 932562 & MUHAMMAD FERIANTO & $\mathrm{L}$ & Salatiga & $05-04-2000$ \\
\hline 1 & 1033015 & ADITYA WAHYU AGUSTI & $\mathrm{L}$ & Salatiga & $15-07-2001$ \\
\hline 2 & 1033016 & ALI MARWAN KHANAN & $\mathrm{L}$ & Kab.Semarang & $12-08-2001$ \\
\hline 3 & 1033017 & ALVIAN WAHYU HIDAYAT & $\mathrm{L}$ & Salatiga & $03-03-2001$ \\
\hline 4 & 1033018 & ANGGA APRILIAN & $\mathrm{L}$ & Kab.Semarang & 17-04-2001 \\
\hline 5 & 1033019 & ARGA FERDIANSYAH & $\mathrm{L}$ & Kab.Semarang & $10-02-2001$ \\
\hline 6 & 1033020 & ARKHA DADANG PRAYOGA & $\mathrm{L}$ & Salatiga & $09-06-2000$ \\
\hline 7 & 1033021 & BAGUS IMAM NAWAWI & $\mathrm{L}$ & Kab.Semarang & $25-09-2000$ \\
\hline 8 & 1033022 & DHIMAS WAHYU ERLANGGA & $\mathrm{L}$ & Salatiga & $22-01-2001$ \\
\hline 9 & 1033023 & DIKA BAGUS PRASETYO & $\mathrm{L}$ & Salatiga & 23-08-1999 \\
\hline 10 & 1033024 & DIMAS RIO SETIAWAN & $\mathrm{L}$ & Kab.Semarang & $21-04-2000$ \\
\hline 11 & 1033025 & DIRGA FARDANUR RAHMAN & $\mathrm{L}$ & Salatiga & 22-11-1999 \\
\hline 12 & 1033026 & EIRLANGGA TUGI WAHYU PAMUNGKAS & $\mathrm{L}$ & Salatiga & $28-03-2001$ \\
\hline 13 & 1033027 & ERWIN & $\mathrm{L}$ & Kab.Semarang & 28-04-1999 \\
\hline 14 & 1033028 & FACHRUL FEBRIAN & $\mathrm{L}$ & Kreungeukueh & $18-02-2001$ \\
\hline 15 & 1033029 & INDRA SETIYAWAN & $\mathrm{L}$ & Kab.Semarang & $13-09-2000$ \\
\hline 16 & 1033030 & KHOTIBUL UMAM & $\mathrm{L}$ & Kab.Semarang & $31-10-2000$ \\
\hline 17 & 1033031 & KURNIAWAN OKTAVIANTO & $\mathrm{L}$ & Salatiga & $17-10-2000$ \\
\hline 18 & 1033032 & LUTFI MUHAMMAD FIKRI & $\mathrm{L}$ & Salatiga & $28-06-2001$ \\
\hline 19 & 1033033 & MARA SEGA AJI PRASETYA & $\mathrm{L}$ & Semarang & 04-03-2001 \\
\hline 20 & 1033034 & MOCHAMAD YAHYA HIKAM & $\mathrm{L}$ & Salatiga & $15-06-2000$ \\
\hline
\end{tabular}




\begin{tabular}{|c|c|c|c|c|c|}
\hline 21 & 1033035 & MUHAMAD AFIF EFENDI & $\mathrm{L}$ & Salatiga & $11-01-2001$ \\
\hline 22 & 1033037 & MUHAMMAD BAHARUDDIN AFFANDI & $\mathrm{L}$ & Kab.Semarang & $10-11-2000$ \\
\hline 23 & 1033038 & MUHAMMAD DICKY FINTYAWAN & $\mathrm{L}$ & Salatiga & $23-10-2000$ \\
\hline 24 & 1033039 & MUHAMMAD DWI ARIFIYANTO & $\mathrm{L}$ & Kab.Semarang & 06-11-2001 \\
\hline 25 & 1033040 & MUHAMMAD FAJAR KURNIAWAN & $\mathrm{L}$ & Kab.Semarang & $13-09-2001$ \\
\hline 26 & 1033036 & MUHAMMAD FARIS SYAIFUR ROHMAN & $\mathrm{L}$ & Salatiga & 24-03-2001 \\
\hline 27 & 1033041 & MUHAMMAD ROBET WILDAN A.M & $\mathrm{L}$ & Salatiga & $22-12-2000$ \\
\hline 28 & 1033042 & MUHHAMAD FAUZI & $\mathrm{L}$ & Salatiga & $28-03-2000$ \\
\hline 29 & 1033043 & PRAWIDANA DINAR TAURISTIAWAN & $\mathrm{L}$ & Salatiga & 24-04-2001 \\
\hline 30 & 1033044 & RIFKI ADI KUSUMA & $\mathrm{L}$ & Salatiga & $09-02-2001$ \\
\hline 31 & 1033045 & SALIS AKBAR HANIFUDIN & $\mathrm{L}$ & Kab.Semarang & $25-05-2001$ \\
\hline 32 & 1033046 & SANDI WARTIKA AZIZ PRANOWO & $\mathrm{L}$ & Kab.Semarang & 01-09-2001 \\
\hline 33 & 1033047 & SONNY TRI LAKSANA & $\mathrm{L}$ & Salatiga & $20-01-2001$ \\
\hline 34 & 1033048 & YOGA ALDI NUGROHO & $\mathrm{L}$ & Kab.Semarang & 04-07-2001 \\
\hline
\end{tabular}

Kelas : X TSM 1

\begin{tabular}{|c|c|}
\hline NO & NISN \\
\hline 1 & 1053178 \\
\hline 2 & 1053179 \\
\hline 3 & 1053180 \\
\hline 4 & 1053181 \\
\hline 5 & 1053182 \\
\hline 6 & 1053183 \\
\hline 7 & 1053184 \\
\hline 8 & 1053185 \\
\hline 9 & 1053186 \\
\hline 10 & 1053187 \\
\hline 11 & 1053188 \\
\hline 12 & 1053189 \\
\hline
\end{tabular}

\begin{tabular}{|l|c|}
\multirow{2}{*}{ AGUS SETIAWAN NAMA } & $\mathrm{L} / \mathrm{P}$ \\
\cline { 2 - 2 } AHMAD ARIF KHOIRUDIN & $\mathrm{L}$ \\
\hline ALDI NUGROHO & $\mathrm{L}$ \\
\hline AMMAR INAN ADHANI & $\mathrm{L}$ \\
\hline ANDYKA CANDRA PURNAMA & $\mathrm{L}$ \\
\hline FATHAN SENA ALAM PRAKASA & $\mathrm{L}$ \\
\hline GRYAN SETYA PERMANA & $\mathrm{L}$ \\
\hline HERNANTO DIMAS PRIAMBODO & $\mathrm{L}$ \\
\hline IDO SAPUTRA & $\mathrm{L}$ \\
\hline JODHY WIRA SANJAYA & $\mathrm{L}$ \\
\hline KHISAN BISRI SYAHARI & $\mathrm{L}$ \\
\hline MUHAMMAD CHOLIT HIDAYATULLAH & $\mathrm{L}$ \\
\hline
\end{tabular}

Wali Kelas : Anggit Dian Nugroho, S.Pd

\begin{tabular}{|l|l|}
\hline TEMPAT LAHIR & TGL. LAHIR \\
\hline Kab.Semarang & $08-08-2000$ \\
\hline Kab.Semarang & $16-07-2000$ \\
\hline Salatiga & $24-12-2000$ \\
\hline Salatiga & $16-07-2001$ \\
\hline Kab.Semarang & $04-07-2001$ \\
\hline Kab.Semarang & $16-04-2001$ \\
\hline Salatiga & $05-04-2002$ \\
\hline Kab.Semarang & $30-09-2000$ \\
\hline Kab.Semarang & $05-03-2000$ \\
\hline Salatiga & $16-05-2001$ \\
\hline Kab.Semarang & $07-12-2000$ \\
\hline Demak & $10-05-2001$ \\
\hline
\end{tabular}




\begin{tabular}{|l|l|l|l|l|l|}
13 & 1053190 & MOHAMMAD ROMADHON & $\mathrm{L}$ & Kab.Tegal & $01-12-2000$ \\
\hline 14 & 1053191 & MUH. FAJAR IZZUL HAQ & $\mathrm{L}$ & Salatiga & $28-10-2000$ \\
\hline 15 & 1053192 & MUHAMAD ANGGA DARMAWAN & $\mathrm{L}$ & Salatiga & $13-03-2001$ \\
\hline 16 & 1053193 & MUHAMAD BAGAR LHUKMANA & $\mathrm{L}$ & Salatiga & $07-07-2000$ \\
\hline 17 & 1053194 & MUHAMAD YAHYA ADAMA & $\mathrm{L}$ & Kab.Semarang & $112-04-2001$ \\
\hline 18 & 1053195 & MUHAMMAD AINUN KAVI & $\mathrm{L}$ & Suruh & $17-06-2000$ \\
\hline 19 & 1053196 & MUHAMMAD FIRMAN AULIA HIMAWAN & $\mathrm{L}$ & Salatiga & $26-06-2000$ \\
\hline 20 & 1053197 & MUHAMMAD HARI YULIANTORO & $\mathrm{L}$ & Salatiga & $06-07-2000$ \\
\hline 21 & 1053198 & MUHAMMAD SYAIFUDIN IQBAL & $\mathrm{L}$ & Salatiga & $13-01-2000$ \\
\hline 22 & 1053199 & NANDA KURNIAWAN & $\mathrm{L}$ & Salatiga & $20-04-2001$ \\
\hline 23 & 1053200 & RAHMAT AJI SETIAWAN & $\mathrm{L}$ & Salatiga & $29-03-2001$ \\
\hline 24 & 1053201 & RIAN PRASETIAWAN & $\mathrm{L}$ & Bekasi & $27-05-2000$ \\
\hline 25 & 1053202 & RISKY BAGUS SAJIWO & $\mathrm{L}$ & Kab.Semarang & $28-03-2001$ \\
\hline 26 & 1053203 & RIYAN ASFARI & $\mathrm{L}$ & Salatiga & $12-06-2000$ \\
\hline 27 & 1053204 & SANDY PERMANA & $\mathrm{L}$ & Salatiga & $31-07-1999$ \\
\hline 28 & 1053205 & SATRIO WICAKSONO & $\mathrm{L}$ & Salatiga & $09-09-2000$ \\
\hline 29 & 1053206 & TAMJIZ ADNAN GHOZALI & $\mathrm{L}$ & Salatiga & $30-03-2001$ \\
\hline 30 & 1053207 & TAUFIK RESTU AJI SAPUTRA & $\mathrm{L}$ & Salatiga & $26-03-2000$ \\
\hline 31 & 1053208 & UJANG PRASETYO & $\mathrm{L}$ & Kab.Semarang & $13-11-1999$ \\
\hline 32 & 1053209 & PUTUT PURNOMO AJI & $\mathrm{L}$ & Salatiga & $06-04-2001$ \\
\hline 33 & 1053210 & YUDI WAHYUDIN & $\mathrm{L}$ & Salatiga & $24-02-2001$ \\
\hline 34 & 1053211 & ZAKKI ANTURIDA & & $12-12-2000$ \\
\hline
\end{tabular}

Kelas : X TSM 2

\begin{tabular}{|c|c|}
\hline NO & NISN \\
\hline 1 & 1053178 \\
\hline 2 & 1053179 \\
\hline 3 & 1053180 \\
\hline 4 & 1053181 \\
\hline 5 & 1053182 \\
\hline
\end{tabular}

\begin{tabular}{l|l|l}
\multirow{2}{*}{ AGUS SETIAWAN } & NAMA & \\
\cline { 3 - 3 } & AHMAD ARIF KHOIRUDIN & \\
ALDI NUGROHO & \\
\hline AMMAR INAN ADHANI & \\
\hline ANDYKA CANDRA PURNAMA & \\
\hline
\end{tabular}

Wali Kelas : Sidiq Suprayogi, S.Pd \begin{tabular}{l|l} 
TEMPAT LAHIR & TGL LAHIR
\end{tabular} \begin{tabular}{l|l}
\hline TEMPAT LAHIR & TGL. LAHIR \\
\hline Kab.Semarang & $08-08-2000$ \\
\hline
\end{tabular} \begin{tabular}{l|l}
\hline Kab.Semarang & $16-07-2000$ \\
\hline
\end{tabular} Salatiga $24-12-2000$ \begin{tabular}{l|l}
\hline Salatiga & $16-07-2001$
\end{tabular} \begin{tabular}{l|l}
\hline Kab.Semarang & 04-07-2001
\end{tabular} 


\begin{tabular}{|c|c|c|c|c|c|}
\hline 6 & 1053183 & FATHAN SENA ALAM PRAKASA & $\mathrm{L}$ & Kab.Semarang & $16-04-2001$ \\
\hline 7 & 1053184 & GRYAN SETYA PERMANA & $\mathrm{L}$ & Salatiga & 05-04-2002 \\
\hline 8 & 1053185 & HERNANTO DIMAS PRIAMBODO & $\mathrm{L}$ & Kab.Semarang & $30-09-2000$ \\
\hline 9 & 1053186 & IDO SAPUTRA & $\mathrm{L}$ & Kab.Semarang & $05-03-2000$ \\
\hline 10 & 1053187 & JODHY WIRA SANJAYA & $\mathrm{L}$ & Salatiga & $16-05-2001$ \\
\hline 11 & 1053188 & KHISAN BISRI SYAHARI & $\mathrm{L}$ & Kab.Semarang & $07-12-2000$ \\
\hline 12 & 1053189 & MUHAMMAD CHOLIT HIDAYATULLAH & $\mathrm{L}$ & Demak & $10-05-2001$ \\
\hline 13 & 1053190 & MOHAMMAD ROMADHON & $\mathrm{L}$ & Kab.Tegal & $01-12-2000$ \\
\hline 14 & 1053191 & MUH. FAJAR IZZUL HAQ & $\mathrm{L}$ & Salatiga & $28-10-2000$ \\
\hline 15 & 1053192 & MUHAMAD ANGGA DARMAWAN & $\mathrm{L}$ & Salatiga & $13-03-2001$ \\
\hline 16 & 1053193 & MUHAMAD BAGAR LHUKMANA & $\mathrm{L}$ & Salatiga & $07-07-2000$ \\
\hline 17 & 1053194 & MUHAMAD YAHYA ADAMA & $\mathrm{L}$ & Kab.Semarang & '12-04-2001 \\
\hline 18 & 1053195 & MUHAMMAD AINUN KAVI & $\mathrm{L}$ & Suruh & $17-06-2000$ \\
\hline 19 & 1053196 & MUHAMMAD FIRMAN AULIA HIMAWAN & $\mathrm{L}$ & Salatiga & $26-06-2000$ \\
\hline 20 & 1053197 & MUHAMMAD HARI YULIANTORO & $\mathrm{L}$ & Salatiga & $06-07-2000$ \\
\hline 21 & 1053198 & MUHAMMAD SYAIFUDIN IQBAL & $\mathrm{L}$ & Salatiga & $13-01-2000$ \\
\hline 22 & 1053199 & NANDA KURNIAWAN & $\mathrm{L}$ & Salatiga & 20-04-2001 \\
\hline 23 & 1053200 & RAHMAT AJI SETIAWAN & $\mathrm{L}$ & Salatiga & $29-03-2001$ \\
\hline 24 & 1053201 & RIAN PRASETIAWAN & $\mathrm{L}$ & Salatiga & $27-05-2000$ \\
\hline 25 & 1053202 & RISKY BAGUS SAJIWO & $\mathrm{L}$ & Bekasi & $28-03-2001$ \\
\hline 26 & 1053203 & RIYAN ASFARI & $\mathrm{L}$ & Kab.Semarang & $12-06-2000$ \\
\hline 27 & 1053204 & SANDY PERMANA & $\mathrm{L}$ & Salatiga & 31-07-1999 \\
\hline 28 & 1053205 & SATRIO WICAKSONO & $\mathrm{L}$ & Salatiga & $09-09-2000$ \\
\hline 29 & 1053206 & TAMJIZ ADNAN GHOZALI & $\mathrm{L}$ & Salatiga & $30-03-2001$ \\
\hline 30 & 1053207 & TAUFIK RESTU AJI SAPUTRA & $\mathrm{L}$ & Salatiga & $26-03-2000$ \\
\hline 31 & 1053208 & UJANG PRASETYO & $\mathrm{L}$ & Salatiga & 13-11-1999 \\
\hline 32 & 1053209 & PUTUT PURNOMO AJI & $\mathrm{L}$ & Kab.Semarang & 06-04-2001 \\
\hline 33 & 1053210 & YUDI WAHYUDIN & $\mathrm{L}$ & Salatiga & $24-02-2001$ \\
\hline 34 & 1053211 & ZAKKI ANTURIDA & $\mathrm{L}$ & Salatiga & $12-12-2000$ \\
\hline
\end{tabular}


Lampiran 12

\section{STRUKTUR ORGANISASI SMK NEGERI 03 SALATIGA}

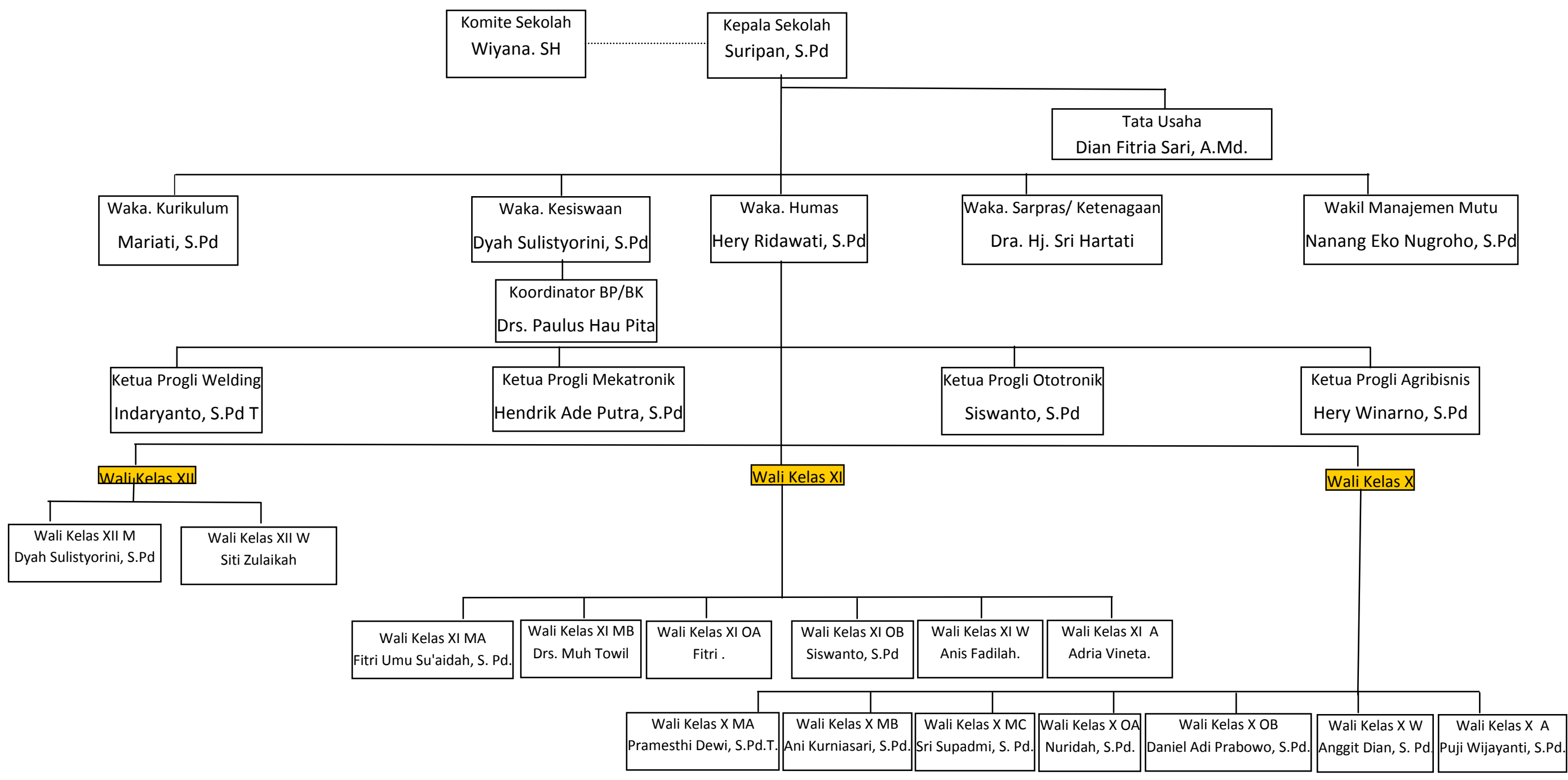


Lampiran 13

\section{HASIL WAWANCARA DENGAN GURU}

$\begin{array}{ll}\text { Nama } & \text { : Sulistyo, S.Pd } \\ \text { Jabatan } & \text { : Guru Seni Musik }\end{array}$

A : apa saja masalah yang dihadapi waktu dalam menerapkan penggunaan media audio visual pak?

B : ya... masalahnya sarana prasarana. Seperti screennya pakai whiteboard kan pengaruh tuh, terus letak dari kelasnya yang terkenapa pencahayaan dari luar dalam tidak bisa gelap tuh. Dan tidak ada tirainya jadinya tidak bisa jelas.

A : bagaimana cara mengatasi masalah tersebut pak?

B : agak sulit ya...kalo ada sih pakek tirai, tapi kalo tidak mungkin hanya menutup pintu biar cahaya tidak masuk.

A : berarti setiap kelas memang tidak ada tirainya ya pak?

B : iya...belum ada tirainya semua, kecuali LAB komputer. Minimal ya menutup pintu itu biar cahaya tidak masuk.

A : kenapa bapak menggunakan audio visual saat pembelajaaran?

B : karena lebih efektif

A : efektifnya gimana pak?

B : efektifnya yaitu siswa langsung melihat langsung, merasakan, melihat mendengar. Kalo dibuku kurikulum 2013 itu kan ada juga sih...materi pementasan, contoh-contoh panggung di outdoor ataupun di indoor itu kan hanya sebatas tau gambarannya, tapi kalo menggunakan media audio visual kan bisa kompleks.

A : kapan media ini diterapkan? Waktu semester genap atau semester ganjil?

B : sebenernya disemester ganjil bisa, karena Kdnya kan hanya empat. Semester ganjil dua dan semester genap dua. Nahh...kalo senikan katakanlah ada teori dan praktek, diteorinya kita butuh media tersebut, jadi disemester ganjil ya butuh di semester genap ya butuh.

A : apa perbedaan menggunakan dan tidak menggunakan media audio visual pak? 
B : Ohh..jelas berbeda ya, siswa lebih antusias dan siswa juga secara real melihat dan mendengarkan. Dibuku panduan sebenernya ada, tapi tidak kompleks cuma menerka-nerka gambar itu apa sih.

A : apa kelebihan dan kekurangan menggunakan media audio visual pak?

B : kelebihannya....jelas untuk guru lebih mudah menyampaikan materi karena ini media, untuk siswa....siswa mudah paham untuk kekurangannya kerena di ruangan tidak ada jadi kita bawa sendiri,angkat-angkat sendiri dan sebagainya. Kemudian sebagai pengajar juga harus menyiapkan dulu materi yang harus disampaikan, seperti contoh pementasan di dalam ruangan sama luar ruangan, ya kan ini juga butuh waktu juga.

A : untuk siswa apakah antusias dengan adanya media audio visual pak?

B : yaa...untuk antusias siswa lebih antusias dari pada diceritakan,sekedar ngomong, gambar siswa itu lebih antusias melihat langsung berupa tayangan berupa media audio visual itu.

A : dari penggunaan media audio visual apakah mempengaruhi terhadap prestasi siswa pak?

B : iyah jelas, dengan paham dulu jadi siswa tahu apa yang dia lakukan dan belajar dari contoh-contoh itu dan juga termotivasi ketika sudah melihat mendapatkan sebuah ide.

A : selain media audio visual apakah ada media yang lain pak?

B : ada...jelas untuk media alat musik karena pelajaran seni, seperti mainesone kan pakai keyboard iringan lagu seperti mengajar lagu mars untuk kelas 10 minimal hafal atau tau lagu mars SMK Negeri 03 Salatiga ya lewat bikin midi di keyboard siswa nyanyi dan diiringi lewat itu lebih cepat. Selain alat musik media nya internet, anak-anak saya perbolehkan untuk buka internet.

A : bawa laptop apa pak?

B : bawa laptop bisa, tablet bisa, smartphone pun tidak masalah, tetapi tetep saya kontrol pembatabas pemakaiannya.

A : itu lebih condong materi apa ya pak?

B : lebih ke teori, teori musik dan sebagainya biar tau sendiri, jadi cari tau sendiri dan mempresentasikan sendiri. Oh... ternyata not seperenambelasan kayak gitu. Keliatannya bosen jika hanya ceramah, fokus pada guru itu bosen. Tapi jika dibuat penugasan atau kelompok mereka lebih antusias.

A : ohh iya pak...untuk sekarang ini memakai kurikulum apa ya?

B : kurikulum 2013 yang sudah revisi, jadi kita mengikuti itu. Dulu sudah ada revisi sekarang juga ada revisi lagi. 
Lampiran 14

DOKUMENTASI

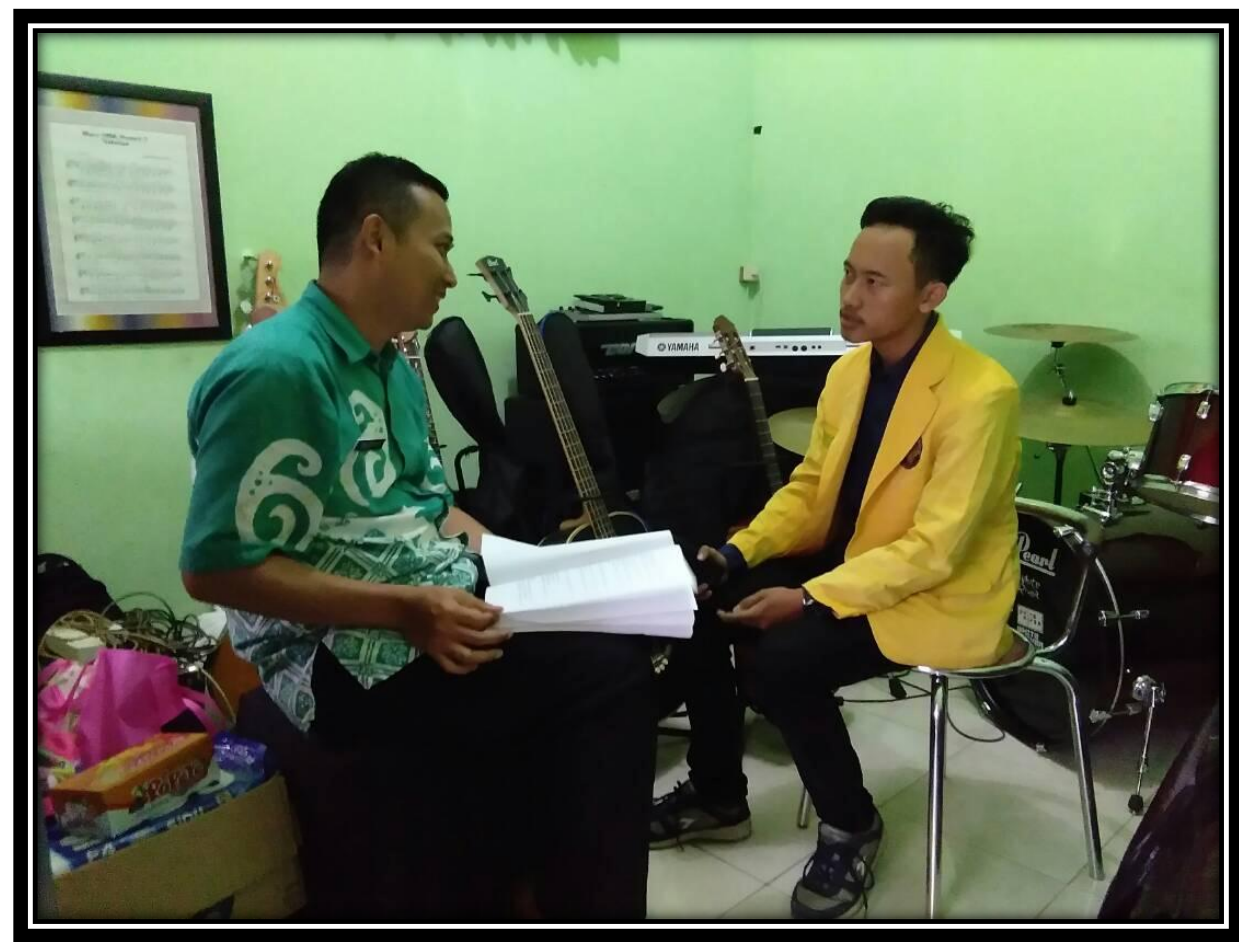

Wawancara dengan Guru Mata Pelajaran Seni Musik

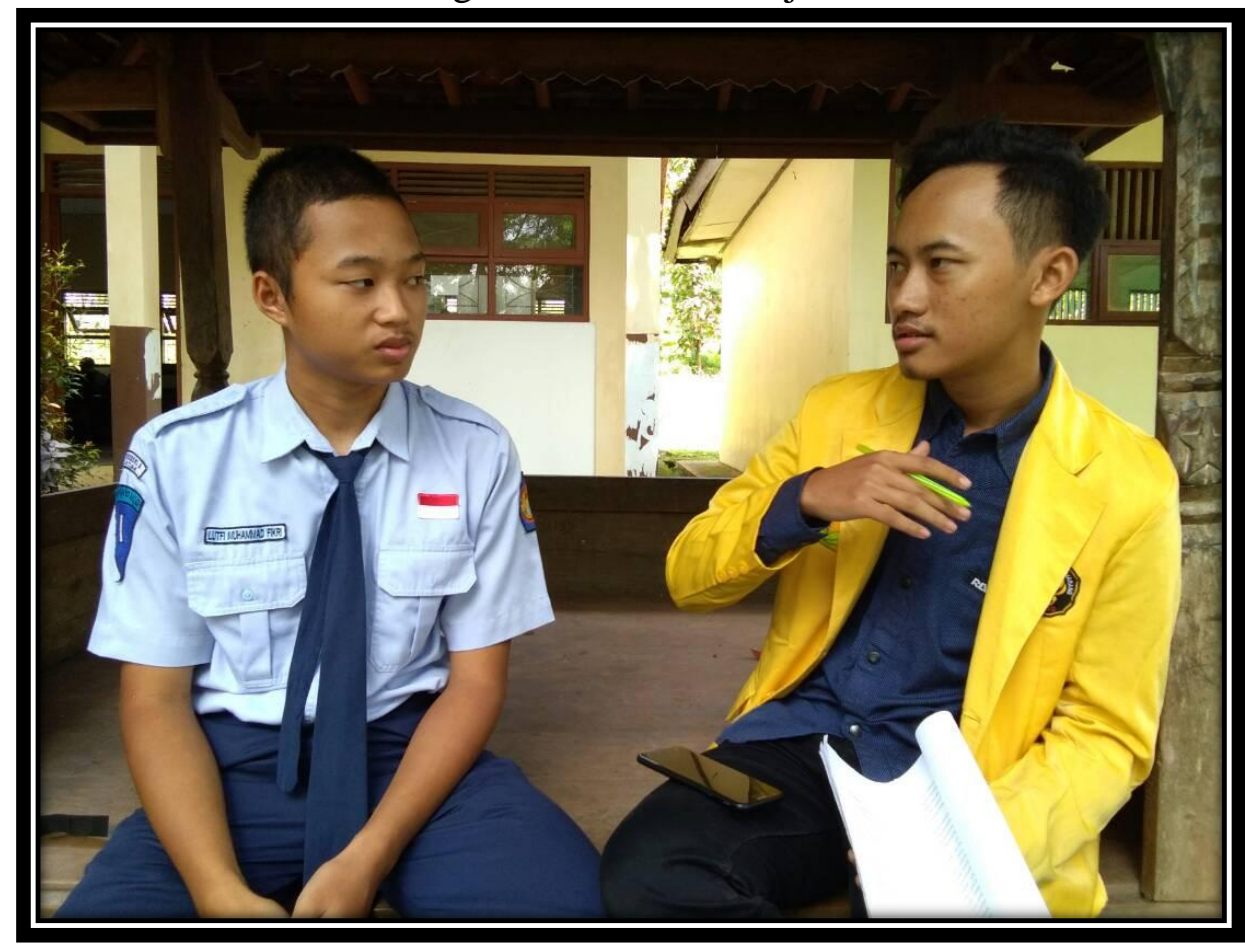

Wawancara dengan Siswa 


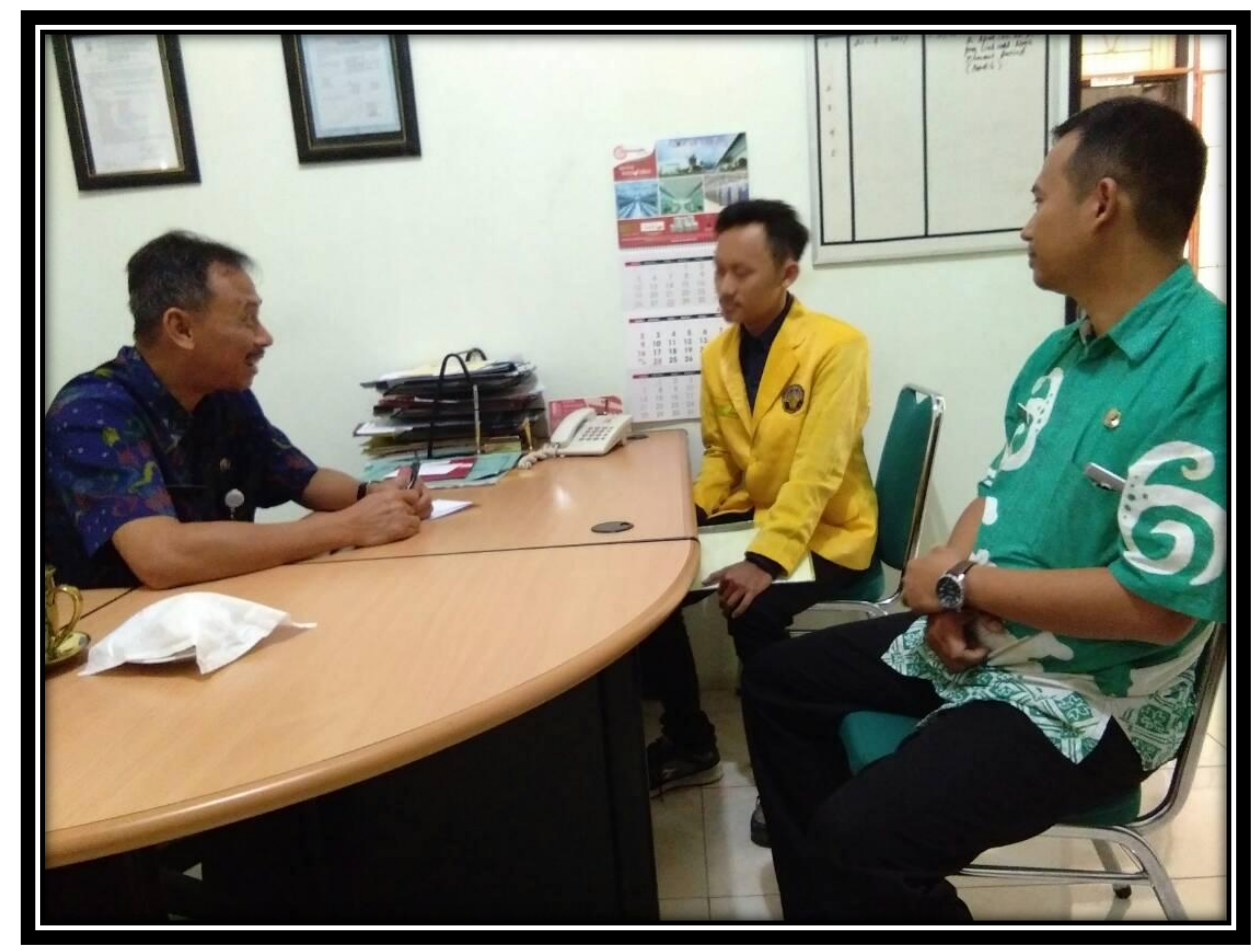

Izin Penelitian Kepada Kepala Sekolah

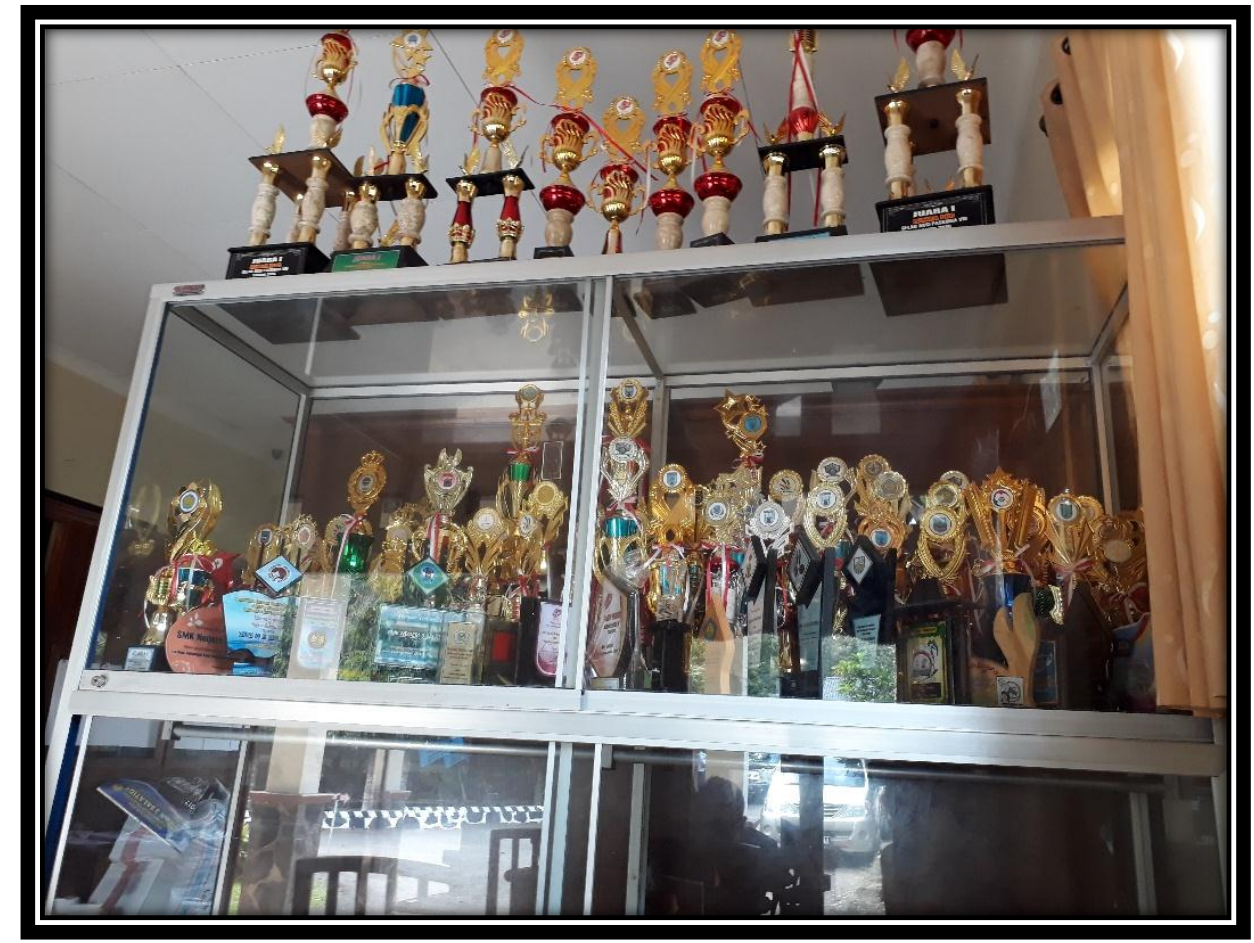

Sebagian Piala Prestasi SMK Negeri 03 Salatiga 